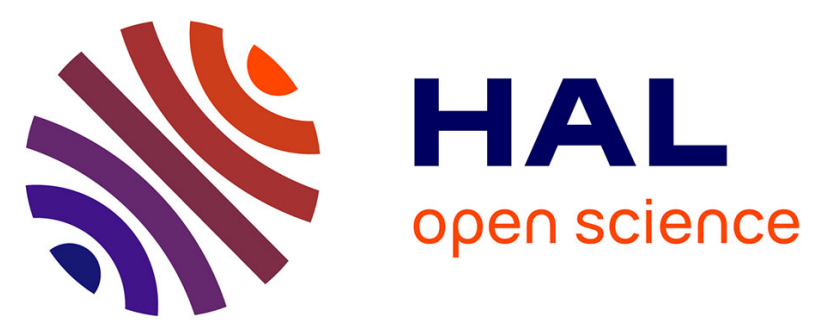

\title{
Carboniferous-Permian transgression/regression mechanisms in the Eastern Ordos Basin and their sea-level spatiotemporal variability: Insights from source-to-sink systems
}

Chao Fu, Xinghe Yu, Shunli Li, Zixiao Peng, Shi Shi

\section{To cite this version:}

Chao Fu, Xinghe Yu, Shunli Li, Zixiao Peng, Shi Shi. Carboniferous-Permian transgression/regression mechanisms in the Eastern Ordos Basin and their sea-level spatiotemporal variability: Insights from source-to-sink systems. Marine and Petroleum Geology, 2021, 123, pp.104722. 10.1016/j.marpetgeo.2020.104722 . insu-02966449

\section{HAL Id: insu-02966449 \\ https://hal-insu.archives-ouvertes.fr/insu-02966449}

Submitted on 14 Oct 2020

HAL is a multi-disciplinary open access archive for the deposit and dissemination of scientific research documents, whether they are published or not. The documents may come from teaching and research institutions in France or abroad, or from public or private research centers.
L'archive ouverte pluridisciplinaire HAL, est destinée au dépôt et à la diffusion de documents scientifiques de niveau recherche, publiés ou non, émanant des établissements d'enseignement et de recherche français ou étrangers, des laboratoires publics ou privés. 


\section{Journal Pre-proof}

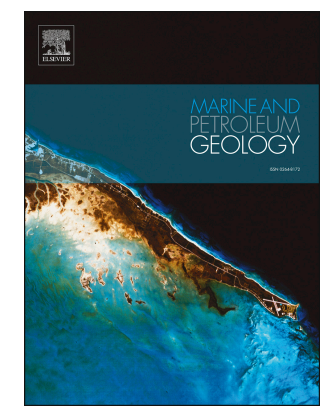

Chao Fu, Xinghe Yu, Shunli Li, Zixiao Peng, Shi Shi

PII:

S0264-8172(20)30505-5

DOI:

https://doi.org/10.1016/j.marpetgeo.2020.104722

Reference: JMPG 104722

To appear in: $\quad$ Marine and Petroleum Geology

Received Date: 12 May 2020

Revised Date: 16 September 2020

Accepted Date: 19 September 2020

Please cite this article as: Fu, C., Yu, X., Li, S., Peng, Z., Shi, S., Carboniferous-Permian transgression/regression mechanisms in the Eastern Ordos Basin and their sea-level spatiotemporal variability: Insights from source-to-sink systems, Marine and Petroleum Geology (2020), doi: https:// doi.org/10.1016/j.marpetgeo.2020.104722.

This is a PDF file of an article that has undergone enhancements after acceptance, such as the addition of a cover page and metadata, and formatting for readability, but it is not yet the definitive version of record. This version will undergo additional copyediting, typesetting and review before it is published in its final form, but we are providing this version to give early visibility of the article. Please note that, during the production process, errors may be discovered which could affect the content, and all legal disclaimers that apply to the journal pertain.

(C) 2020 Published by Elsevier Ltd. 
Chao FU: Writing- Original draft preparation

Xinghe YU: Supervision.

Shunli LI: Visualization, Investigation.

Zixiao PENG: Software, Validation.

Shi SHI: Software 
1 Carboniferous-Permian transgression/regression mechanisms in the Eastern

2 Ordos Basin and their sea-level spatiotemporal variability: Insights from

\section{source-to-sink systems}

Chao $\mathrm{Fu}^{1,2}$, Xinghe $\mathrm{Yu}^{1 *}$, Shunli $\mathrm{Li}^{1}$, Zixiao Peng ${ }^{1}$, Shi Shi ${ }^{3}$

1 School of Energy, China University of Geosciences, Beijing 100083, China

2 Rennes Geosciences, Université de Rennes 1, Rennes 35000, France

3 Coalbed methane company, China National Petroleum Corporation, Beijing 100020 China corresponding author: billyu@cugb.edu.cn

Abstract: Developed on the North China Craton, the intracratonic Ordos Basin contains a complete Paleozoic-to-Cenozoic sediment record, allowing for long-term paleoenvironmental and climate change investigation. During the Carboniferous-Permian period, convergence between the North China block and the paleo-Yangtze plate to the south resulted in a general marine regression characterized by a series of second-order transgression/regression cycles diachronous along the eastern margin of the Ordos. However, the detailed mechanisms that induced these cycles, as well as the associated paleoecological changes, remain unknown. In this study, we integrate multiple indices, including $\delta 180$ and $\delta 13 \mathrm{C}$, rare earth element (REE), paleontological assemblages, and clay content $(w$ (chlorite + kaolinite $) / w((I l l i t e)$ ratio) planar distribution, to restore the paleo-water depth distribution. These parameters are then used to reconstruct the paleo-sea level from the Pennsylvanian to the middle Permian. We conclude that the direction of second-order transgression/regression was mainly toward the east during the Pennsylvanian-early Permian and switched clockwise toward the north during the middle Permian. We suggest that the second-order cycles, diachronous in space and time, are mainly 
linked to local variations in sediment supply and regional uplift. Using detrital zircon $\mathrm{U}-\mathrm{Pb}$ data and the REE and trace element content and heavy mineral assemblages (HMA), we estimate the sediment provenance area. The sediment volumes deposited in the basin through time are obtained using 2D seismic data. During the Carboniferous, the coarse-grained sediments deposited in the eastern Ordos were derived from the uplifting Helan Mountain (Qiandam-Qilian orogenic belt). By the middle Permian, the detrital material became multi-sourced, thus issuing the Yinshan range to the north and the Qinling range to the south. We then integrate the description of numerous core samples with electric log and 2D seismic data to reconstruct the sediment facies associations across the first-order regression from the Carboniferous tidal flat depositional system to the middle Permian prograding fluvial delta system. According to the transfer of the glacial epoch, the sedimentation rate, and the transgression/regression rate above, we classify the evolution process into three patterns: low-transgression rate and less-sediment supply pattern (the late Carboniferous), high regression rate and mass sediment supply pattern (the north block during the early Permian), and low regression rate and mass sediment supply pattern (the south block during the Sakmarian stage). Lastly, with the quantitative calculation of the source-to-sink (S2S) parameters, including the S2S system volume and the elevated height of regional uplift with the $2 \mathrm{D}$ seismic data, we propose the mechanism of transgression/ regression in the Ordos Basin, responding to the above three pattern s. The first pattern was controlled by regional uplift, whereas the second pattern was controlled by sediment supply. As to the third one, uplift and sediment supply could affect the transgression/regression process.

Keywords : Transgression mechanism, Provenance identification, Detrital geochronology data, Paleontology data, Pennsylvanian-Permian transition 


\section{Introduction}

An intracratonic basins is characterized by the preponderance of thermal subsidence over tectonic subsidence, making for largely stable long-term subsidence rates. Sedimentary sequences in this type of basin generally preserve a complete sedimentary record that allows deciphering the large-scale paleoenvironmental evolution (Sloss, 1963; McLaughlin et al., 2004; Zhu et al., 2008; Hoffmann et al., 2009). When affected by marine incursions, these basins provide a good record of water-depth fluctuations and associated transgression/regression mechanisms (Nikishin et al., 1996; Martins-Neto et al., 2001; Alkmim and Martins-Neto, 2012; Bumby et al., 2012). As a typical intracratonic basin in the western part of the North China Block, the Ordos Basin (Wang et al., 2019; Yin et al., 2019; Shi et al., 2020) contains a complete Carboniferous-Permian sedimentary record of transgression/regression cycles closely related in time to a transition from a glacial period to an interglacial one (Tabor and Poulsen, 2008; Koch and Frank, 2011; Xu et al., 2020).

Previous studies have pointed out that with the end of the Late Paleozoic Ice Age (LPIA) during the late Permian, the increase in rainfall resulted in additional sediment supply worldwide, leading to a marine regression process in shallow-marine basins (Golonka and Ford, 2000; Tabor and Poulsen, 2008; Koch and Frank, 2011). However, Stollhofen et al., (2000) pointed out that the transgression/regression process shows a spatiotemporal variability within the large study area. Using stable isotope analysis $\left(\delta^{13} \mathrm{C}\right.$ and $\left.\delta^{15} \mathrm{~N}\right)$ in the eastern margin area (EMA) of the Ordos Basin, Xu et al. (2020) further highlighted the complexity of the transgression/regression events. Meanwhile, Zhu et al. (2008) and Zhang et al. (1997) suggested that during the Carboniferous-Permian, the water depth in the EMA continuously declined due to uplift of the 
basin margins (FIG. 1). Finally, Jiang and Wang (2012) demonstrated that the main direction of the transgression/regression phases changed constantly through time, adding complexity to the water-depth fluctuation pattern.

Several authors have suggested that tectonic movements linked to continental accretions along the margins of the North China Craton had been the main driving mechanism of water depth changes in the basin (Qin et al., 2002; Yang et al., 2005). However, by focusing their models on the effects of tectonics, these studies neglected the influence of changes in climate and sediment supply rates, which are also factors of water-depth fluctuation, particularly in shallow, marginal basins (Haq et al., 1987; Haq and Schutter, 2008a; Labaune et al., 2008; De Falco et al., 2015; Fu et al., 2019). Indeed, existing studies have shown that on the eastern margin of the Ordos Basin, the direction of the main sediment supply changed during the Carboniferous-Permian period, implying changes in regional topography and erosion pattern (Kröner et al., 2006; Darby and Gehrels, 2006; Milne et al. 2009; Zhu et al., 2011). Regarding intracratonic basins, Klein (1982) suggested that an arid climate can potentially change the ratio between clastic and carbonate deposits and indirectly affect water depth.

In this study, we point out the water-depth variations and derive local and regional transgression/regression cycles for the Pennsylvanian-to-early-Permian period. We then integrate detrital zircon U-Pb analysis, heavy mineral assemblages (HMA), and trace elements indexes to determine major changes in sediment sources, climate, transport conditions, and depositional environments. We then quantitatively compare the sediment composition and supply rates to water-depth fluctuations and propose three major source-to-sink (S2S) patterns for the late Paleozoic eastern Ordos Basin: low-transgression rate and limited sediment supply (LT-LS), 
low-transgression rate and massive sediment supply (LT-MS), and high-transgression rate and massive sediment supply (HT-MS). Finally, the response to these various patterns in terms of water-depth variations is described to document the transgression/regression cycles during the final stage of the LPIA.

\section{Geological Setting}

The Mesozoic-to-Cenozoic geologic history of Central China has been strongly influenced by continental accretion events along the southern margin of the Eurasian continent. These geodynamic events drove the formation and sometimes the reactivation of mountain ranges such as the Lvliang and Helen-Liupan Mountains east and west of the Ordos Basin, the Yinshan Mountain to the north and the Qinling Mountain to the south (FIG. 1). The Ordos Basin itself is formed by several depressions such as the East margin, Hetao, Weihe, and Yichuan depressions while major faults control the basin boundaries. The evolution of the Ordos Basin can be divided into five main stages: it initiated as a Cambrian-Early Ordovician continental rim basin, evolving towards an intracratonic basin in a Middle Ordovician-Middle Triassic generally compressive geodynamic setting; during the Late Triassic-Early Cretaceous the basin was affected by thermal subsidence before being inverted and eroded during the late Cretaceous to Neogene compressive event (only some Cenozoic loess are preserved in the south part the basin (Yuan et al., 2007)).

The sedimentary sequence preserved in the EMA ranges from $7 \mathrm{~km}$ to $10 \mathrm{~km}$ in thickness (Yang et al., 2005). During the Ordovician to Mississipian period, tectonic activity induced uplift of the eastern margin of the Ordos Basin (present-day reference frame) leading to a regional parallel unconformity between the basement and the Pennsylvanian deposits (Yang et al., 2005). 
111 The Pennsylvanian to Permian series are divided into the following formations: Penci $\left(C_{2} b\right)$,

112 Taiyuan $\left(\mathrm{C}_{2} t\right)$, Shanxi $\left(\mathrm{P}_{1} \mathrm{~s}\right.$ itself divided into the upper and lower $\mathrm{P}_{1} \mathrm{~s}$ members), Lower Shihotse

113 ( $\mathrm{P}_{2}$ sh), Upper Shihotse $\left(\mathrm{P}_{3} \mathrm{sh}\right)$, and Shiqianfeng $\left(\mathrm{P}_{3} \mathrm{~s}\right)$ (FIG.2).

114 During the deposition of the Penci Formation (Fm.), the sedimentary record displays a sharp 115 regression phase generally associated to the uplift of the central part of the Ordos region. The 116 facies association evolves from a shallow marine setting to a coastal swamp environment. Based 117 on core sample interpretation, Zhang et al. (1997) and Jiang and Wang (2012) indicated that 118 alluvial fan or braided delta depositional environments dominated in the northern part of the study area. Stanley and Powell (2003) stated that in the late Pennsylvanian period, the arid climate and the correlatively reduced amount of sediment injected into the basin resulted in the development of thick limestone and coal seams in the Taiyuan Fm. However, the sea level showed a gentle transgression, and a carbonate platform dominated during this period.

In the early Permian, the convergence between the South China and North China plates largely modified the paleomorphology and paleoecology of the Ordos region. Furthermore, the increasing sediment supply from multiple directions led to a gentle regression from the Asselian to the Kungerian stages (Shanxi Fm.). The combined studies of Zhang et al. (1997), Zhu et al. (2008), and Xin et al. (2018) pointed out that deltaic environments dominated in the EMA, with large marshes separating the distributary channels. With the decrease in sea level, the meandering channels in the delta plains were replaced by braided river environments marked by sand bars and crevasse splays.

\section{Data and methodology}


The EMA of the Ordos Basin has been explored by $3700 \mathrm{~km}$ of $2 \mathrm{D}$ seismic and $1000 \mathrm{~km}^{2}$ of

134 IsoplotR® software provided by University College London, UK (http://pieter-

3D high-resolution seismic data. Furthermore, we get access to 15 wells drilled in the EMA. The positions of the cross-well seismic sections used in this study are shown in FIG. 1a. Electric welllog data, including gamma ray (GR), were acquired and processed by Schlumberger $\AA$. We get the core samples from wells DJ12, Y253, DJ43, G10, G6, and DJ19 (FIG. 3). Heavy and clay mineral content and their scanning electron microscope (SEM) photographs as well as whole rock trace elements analysis from wells $\mathrm{H} 4, \mathrm{Y} 787, \mathrm{G} 3$, DJ43, DJ53, Y521, Y653, and Y432 were processed by the Geological Laboratory of the Research Institute of C.M.B. company (China National Petroleum Corporation CNPC®). The paleontological identifications, including pollen and plant assemblages from wells G3, H4, DJ43, DJ53, and Y787, were completed by the Langfang Branch of Petrochina Exploration and Development Research Institute (CNPC®).

$$
\text { LA-ICP-MS U-Pb analysis of detrital zircons from four core samples (DJ53 } 1942.23 \text { m, H5 }
$$
$1968.1 \mathrm{~m}$, DJ51 $2264.85 \mathrm{~m}$, and G2 $2048.1 \mathrm{~m}$ ) was completed by the Chinese Academy of Geological Sciences ${ }^{\circledR}$ (Appendix TABLES 1-4). Laser ablation was conducted using a NWR193UC $193 \mathrm{~nm}$ deep ultraviolet laser ablation sampling system (Elemental Scientific Lasers, USA). Mass spectrometry was calculated using an Agilent 7900 inductively coupled plasma mass spectrometer (Agilent, USA). One hundred twenty detrital zircons from each sample were analyzed with a spot size of $30 \mu \mathrm{m}$. Every five analyses were followed by one analysis of standard zircon 91500 and GJ. Common lead correction was conducted using ComPbCorr\#3_15G. The U-Pb age calculations and Concordia diagram were completed using

154 vermeesch.es.ucl.ac.uk/shiny/lsoplotR/). Only zircon ages concordant within $90 \%-110 \%$ were 
considered in the subsequent discussion.

$$
\delta^{18} \mathrm{O} \text { and } \delta^{13} \mathrm{C} \text { data were analyzed from whole-sediment mudstone, limestone, or coal }
$$
samples from cores Y787, DJ53, DJ43, H4, and G4 (some carbonate poor layers did not provide reliable data and results were not reported). The $\mathrm{C}$ and O-isotope analyses results are normalized to the Pee Dee Belemnite (PDB) standards with a precision of $\pm 0.1 \% \circ$ for $\delta{ }^{13} \mathrm{C}$ and $\pm 0.2 \%$ for $\delta^{18} \mathrm{O}$.

\subsection{Methodology}

1) Sedimentology and stratigraphy analysis from drill cores and seismic data

Facies association were established from core samples according to the sedimentary structure (FIG.3) and the grain-size distribution (FIG.4). Geophysical log data were then used to constrain the depositional environment setting, such as the bell or cylinder shape of the GR curve (indicating a decreasing flow rate), or a sharp decrease of the DEN curve (or sonic/neutron porosity curve) indicating the occurrence of coal. Finally, associating well and 2D seismic data we reconstructed the stratigraphic and depositional environment pattern of the EMA of the Ordos Basin through time. The 2D seismic profiles were studied and interpreted following the methodology previously established by Pu et al. (2009), Xu et al. (2016), and Anees et al. (2019) in the Ordos Basin. Three types of seismic facies were used as guidelines: the concave, convex, and plate shapes. Following that approach, a seismic package with a concave boundary was generally interpreted as an eroding channel. Associating the log data to the seismic image, it was possible to distinguish between deposited tidal channels, braided channel belts and depositional meandering channel belts. Convex-shaped seismic facies were generally interpreted as depositional tidal barriers. The plate-shaped seismic facies, characterized by a high amplitude 
seismic reflection, generally indicate the development of carbonated tidal platforms.

2) Identification of sediment provenance area and calculation of supply rates.

By combining the results of previous studies constraining the provenance area of the EMA during the late Paleozoic (Darby and Gehrels, 2006; Kröner et al., 2006; Zhu et al., 2011; Song et al., 2012; Xie and Heller, 2013; Sun et al., 2014), we established a mean zircon U-Pb age distribution for the EMA. Using both the age data for the basement rocks, the zircon-tourmalinerutile (ZTR) index (provides indications on the distance of sediment transportation), grains size, sediments Rare Earth Elements patterns and informations on the tectonic background (Darby and Gehrels, 2006; Xie and Heller, 2013), we evaluated the evolution of the main provenance area during the interval from Pennsylvanian to the early Permian.

The sediment supply rates through time were calculated using the provenance data obtained from the method described above and a series of selected 2D seismic profiles. The thickness of the main sediment layers (A parameter hereafter) corresponding to the Bashkirian to Sakmarian stages was obtained from seismic data. As shale deposits have a much higher compaction coefficient then sandstone layers we divided the strata using the sand content (over $80 \%$ ) observed within the corresponding reference wells (Yang et al., 2008; Zhang et al., 2009; Zou et al., 2013). Pre-compaction thicknesses were then calculated using compaction coefficients of $0.0004 \mathrm{~m}^{-1}$ for mudstone and $0.00025 \mathrm{~m}^{-1}$ for sandstone (Zhang et al., 2009). Finally, the stratigraphic and geochronology data obtained in reference wells were used as time constrains $(T)$ to derive sedimentation rates $\left(v_{\text {sediment }}=\mathrm{A} / \mathrm{T}\right)$.

3) Regional paleo-sea level reconstruction via multi-index integration As sea level fluctuates all the time, the lateral facies variations observed in the sedimentary 
record may lead to some illusion and contradiction in the reconstructed regional paleo-sea level.

200

In this study we computed the relative sea level of the Ordos Basin EMA based on the $\delta^{18} \mathrm{O}$ and 201 $\delta^{13} \mathrm{C}$ data from the high organic matters mudstone and comparing to the similar curve obtained 202 by Xin et al. (2018). Our interpretation takes tinto account the fact that the warming climate during 203 the Carboniferous-Permian transgression accounted for an increase of $0.008-0.01 \% \mathrm{~m}^{-1}$ of the 204 $\delta^{18} \mathrm{O}(\mathrm{V}$-PDB $)$ value (Adkins et al., 2002; Elderfield et al., 2012).

205 spp.-Conchophyllum plant association are characteristic of the Bashkirian-Kasimovian stage. 207 During the Gzhelian-Asselian stage, the representative paleontological assemblage is composed 208 of Neurpteris pseudovata and Lepidodendron posthumii. Then, with the warming climate, 209 Emplectopteridium alatum-Cathaysiopteris whitei-Emplectopteris triangularis occurred during the 210 Sakmarian-Kungurian stage (Hilton and Cleal, 2007). Some species (Zygopteris and Ankyropteris 211 corrugated) accumulation, including their macro-remains and pollen, reflected an onshore setting 212 (Phillips and Galtier, 2005; Phillips and Galtier, 2011). Hence, we calculated the ratio of fern 213 species biomass and the plant fossil identified( $w$ biomass $)$ in G3, H4, DJ43, DJ53, and Y787 and 214 obtain their responding relative sea level. Furthermore, according to the morphology of all the 215 identified species in the core samples of the EMA (Hilton and Cleal, 2007; Pfefferkorn and Wang, 216 2007), broadleaf ferns were prominent during the late Paleozoic although their preservation in the 217 fossil record was affected by post-deposition sediment reworking processes (Bacon et al., 2016). 218 Previous studies have pointed out that at the high stand of the sea level, the amount of leaf fossil 219 in the core samples ( $\left.w_{\text {leaf }}\right)$ is larger than the root or steam fossil due to the hydrodynamic process 220 of tide or wave (Pratt et al., 1978; Gastaldo, 2004; Gee, 2005). Thus, according to the ratio 
between the leaf fossil and the root/ steam fossil ( $\left.w_{\text {leaf }}\right)$, we can infer the relative sea level.

Clay mineral assemblages provide another evidence for the late Paleozoic relative regional

223

224

225

226

227

228

229

230

231

232

233

234

235

236

237

sea-level proxy. The Panthalassic ocean margin was located east of the EMA and south of the

Paleo-Tethys (http://www.scotese.com/). The clay mineral assemblages of the Panthalassic ocean (Kemp and Izumi, 2014) and Paleo-Tethys (Cheng et al., 2019) display a high value of illite. By contrast, the clay mineral assemblage of the potential source area is mainly chlorite and kaolinite (Zhang et al., 1998). Thus, the deposition of the marine original sediment will lead to a gentle increase of the illite content in the sediment. That is to say, the illite shows a much weaker positive relationship to the transgression process. According to the method mentioned in Fu et al. (2019a and b), we calculated the $w_{c l a y}=w($ chlorite + kaolinite $) / w(($ illite $)$, and variations in this parameter are inversely correlated to the variations in sea-level.

The trace element ratios including $\Sigma \mathrm{LREE} / \Sigma \mathrm{HREE}, \mathrm{Sr} / \mathrm{Br}, \mathrm{Ce} / \mathrm{La}, \mathrm{Rb} / \mathrm{Zr}, \mathrm{CaO} /\left(\mathrm{MgO} \times \mathrm{Al}_{2} \mathrm{O}_{3}\right)$, and $\mathrm{V} /(\mathrm{V}+\mathrm{Ni})$ were also obtained from core samples in wells G3, H4, DJ43, DJ53, and Y787 . Values of $\mathrm{V} /(\mathrm{V}+\mathrm{Ni})>0.54, \mathrm{Sr} / \mathrm{Br}>0.5$, and $\mathrm{Ce} / \mathrm{La}>1.5$ are interpreted as characteristic of a shallow-marine environment, the other values indicating a continental setting (Rimmer, 2004). Referring to the above critical condition, we obtained the relative regional sea-level fluctuation in accordance with the trace element in.

Transgression/regression rate calculation: based on the transgression/regression directions established above, we used 2D seismic data to identify the successive transgression events and calculate their distance of propagation (S). As indicated by the sediment thermal evolution history diagram previously obtained on these series (see Yu et al., 2012; Ren et al., 2007), the subsidence rates varied through time but remained spatially coherent (no large variations 
throughout the study area at a given time). Subsidence was nearly null during the Pennsylvanian

244 interval, while it reached $30 \mathrm{~m} / \mathrm{Ma}$ during the early Permian. Accordingly, the subsidence rate was

245 used as an input parameter in the transgression/regression rate calculationA following the 246 equation:

$$
S=\left(D_{\text {compaction }}+D_{\text {subsidence }}\right) / \cos (\alpha)
$$

D compaction is the decompacted thickness of mudstone in the strata; $D$ subsidence is the interpretation of the seismic profile.

Finally, by eliminating the subsidence impact factors, we calculated the transgression/regression distance $(\mathrm{S})$ using $\left(\mathrm{v}_{\text {sea }}\right)$ as $\mathrm{v}_{\text {sea }}=\mathrm{S} / \mathrm{T}$, in which $\mathrm{T}$ is time.

\section{Lithofacies identification and association classification}

During the transgression/regression process in the Carboniferous-Permian, the grain size and lithology exhibited a dramatic change from conglomerate to mudstone. The series are also containing well-identified layers of coal, limestone, quartz sandstone, and feldspar sandstone. In this study, we defined 6 lithofacies associations using lithofacies previously established by Zhu et al. (2008), Yang et al. (2017), and Xin et al. (2018) in Ordos basin: massive mudstone (M); bioturbated sandstone (Sb); muddy strip composite sandstone (Scm); slumped sandstone (Sd); cross-bedding composite sandstone (Scc); cross-bedding sandstone (Sc); massive sandstone (Sm); planar cross-bedded sandstone (Sp); massive gravel (Gm); planar cross-bedded gravel (Gp) (FIG. 3 and TABLE.1).

\section{Identification of depositional environments from seismic and well data.}

We selected two seismic profiles in an EW direction and calibrated them using wells G6 and 
DJ12 as references. Based on this calibration, we defined depositional environments and created

266 a stratigraphic column.

\subsection{Pennsylvanian depositional environments}

As shown from core samples in well G6, the lithofacies association evolved upward from LFA.5 to LFA.4, LFA.4, LFA.5, and finally LFA.6. Based on lithofacies interpretation in FIG.3, the early Pennsylvanian period was characterized by an initial bidirectional slow-rate traction flow deposit, evolving upward toward a coarse-grained flow . Finally, facies LFA.5 and LFA.6 indicate a weak hydrodynamic intensity during the late Pennsylvanian period. The cumulative grain-size curve in FIG. 4 also shows this last depositional environment evolution from a mass flow ( $g$ and $f$ ) up to a tidal-dominated shallow-water setting (a to e). Additionally, fusulinid fossil typical of shallow marine environments were observed at a depth of 2,431 m in well G6,(Liu et al., 2015). The morphology of the GR curve also indicated the depositional environments in upward layers as having been transient. In the early Pennsylvanian interval, the well-logging GR curve of sandstone mainly showed a bell (2455m in G6 FIG.4) or cylinder shape (2450 m in G6 FIG.6), indicating a rising sea level and an increase in flow dynamics. For the late Pennsylvanian interval, the combination of the GR curve and the corresponding density curve (or sonic/neutron porosity curve) highlight the occurrence of coal layers interbedded in limestone, characterizing a decreasing sea level and a weakening flow rate. The Pennsylvanian period is thus marked by a transgression phase followed by regression. However, regionally, the sea level showed a marked spatiotemporal variability discussed below.

Well G6 was used to calibrate the facies pattern on the seismic line shown on FIG. 4. The reflectors showing concave interfaces indicated erosion in tidal channel belts, while convex 
interfaces are interpreted as sediment accumulation in tidal barriers. The tidal-dominated deposit

288 (including the barrier and the tidal channel deposit) thus mainly developed during the early 289 Pennsylvanian period.

\subsection{Development of depositional environments during the early Permian period}

The core samples in well DJ12 show a vertical evolution of lithofacies associations from

292

LFA.6-LFA.2-LFA.1 (Table 1). The high-rate flow deposits of LFA.2 developed during the Asselian to Sakmarian interval. Deposition of LFA.1 including large mud clasts and lamellar cross-bedding indicate a slowing flow rate upward. As the cumulative grain-size curve in FIG. 5 shows, two curve-pattern segments indicate a decreasing amount of suspended sediments and a flow-pattern evolution toward a one-directional traction flow. On the corresponding well-logs, the GR curve developed as a cylinder at the bottom and as a bell shape upward. This again indicate that the Asselian to Sakmarian interval can be divided into two cycles corresponding to a gentle transgression process.

FIG 5 displays a series of concave and convex seismic facies according to the seismic boundaries. Referring to the study of Zhu et al. (2008) and Xin et al. (2018), we infer that braided channels (delta) initially developed, before being replaced upward by meandering channels. The seismic packages ascribed to the Asselian period show low amplitude and high continuity patterns. According to Xin et al. (2018), the lateral migration events indicate that sandy sedimentary facies (such as braided delta) developed in the Asselian period, while upward toward the Sakmarian interval, we suggest that high amplitude and low continuity events represent a muddy depositional environment.

\section{Results}


Detrital zircons $\mathrm{U}-\mathrm{Pb}$ age data are used to constrain the potential source area of sediments deposited in the Ordos basin during the Pennsylvanian to the early Permian. Four samples were zircon CL images are shown on FIG.6. For the Pennsylvanian interval we refer to data from Sun et al. (2014) (samples JC-A and JC-B). Representative zircon CL images are shown in FIG. 6, Concordia plots in FIG.7 and individual age spectrums in FIG.8. oscillatory zoning and $\mathrm{Th} / \mathrm{U}$ ratios are generally over 0.1 , indicating intermediate source rock types such as granitoids and metamorphic rocks (FIG.9 a). The obtained detrital zircon U-Pb ages can be divided into three groups: 273-307 Ma, 762-974 Ma, and 1168-2543 Ma. can be divided into three types according to their external morphology and internal structure. The first type is rounded/sub-rounded with a length/width ratio of 1:1.5 and shows a well-preserved magmatic oscillatory zoning. The second type has a length/width ratio of $1: 3$ and is angular/subfrom $1800 \mathrm{Ma}$ to $1900 \mathrm{Ma}$ (see crystals date at $1827 \pm 20 \mathrm{Ma}$ (DJ53) or $1803 \pm 22 \mathrm{Ma}(\mathrm{H} 5)$ on 
zoning implying a metamorphic source, especially for samples over $2000 \mathrm{Ma}$. A total of 180

332

333

334

\section{in TABLE.2.}

crystals were analyzed for those two samples, and 168 of these, with a $>90 \%$ concordance were considered adequate (age data in Appendix Tables 1 and 2). The individual age are grouped into four classes: 310-375 Ma, 410-490 Ma, 1650-2300 Ma, and 2300-2500 Ma (FIG. 7).

Samples DJ51 and G2 were collected from the Sakmarian series. As shown in the CL image of FIG. 6, zircon crystals of DJ51 and G2 are mostly angular/subangular with a length/width ratio of less than 2:1 and show a dark oscillatory zoning and bright overgrown homogeneous rim. The $\mathrm{Th} / \mathrm{U}$ ratio ranging from 0.03 to 0.7 indicates intermediate rock sources. The $\mathrm{U}-\mathrm{Pb}$ Concordia plots in FIG. 5 shows that the concordance of all the grains (85 gains in DJ51 and 94 grains in G2) is over $90 \%$. The $\mathrm{U}-\mathrm{Pb}$ age spectrum of DJ51 and G2 reveals two groups at 275 to $450 \mathrm{Ma}$ (peak value of $375 \mathrm{Ma}$ ) and $1750-2000 \mathrm{Ma}$.

\subsection{Heavy mineral assemblages}

Six types of heavy minerals (rutile, zircon, tourmaline, titanite, apatite and pyrite) were quantified from core samples and classified in five types using the Heavy Minerals Associations (HMA) of Morton and Hallsworth (1994) and the statistical approach of Andrew (1985) : rutiledominated (HMA-I), pyrite-dominated (HMA-II), titanite-dominated(HMA-III), tourmalinedominated, (HMA-IV), and zircon-dominated (HMA-V) (FIG. 10). In order to allow comparison, the HMA of potential source areas around the Ordos Basin, which includes the Qaidam-Qilian orogenic belt (QQOB) in the west, Yishan Orogenic belt (YOB) in the north, and Qinling orogenic belt(QOB) in the south, and their dominated HMA types are obtained from bibliography are listed

The early Pennsylvanian deposits are characterized by HMA-II and HMA-III associations. 
Similar associations, dominated by HMA-II are observed in the early Pennsylvanian deposits of

354

the QQOB, YOB suggesting common sediment sources(Chen et al., 2009; Du et al., 2017). The pyrite content in wells $\mathrm{Y} 521, \mathrm{H} 4, \mathrm{Y} 787$, and $\mathrm{Y} 653$ is over $60 \%$, which suggest that some sediment may be transported from the QQOB. Besides that, we compared the HMA in DJ43, DJ53, and that in the YOB (Ruppen et al., 2014; Li et al., 2014); both show HMA-III. Based on the increase in that new source area we speculate that some sediment migrated far south from the northern Ordos margin.

After the deposition of the late Pennsylvanian series, the pyrite content in well Y787 decreased sharply, whereas the proportion of tourmaline considerably increased. This result suggests that more sediment from the QQOB were either routed towards another basin or deposited in a proximal area and not transported into the Ordos sink area. The well in the northern EMA underwent an increase in zircon and rutile content, suggesting that a substantial amount of sediment came from the YOB.

During the Asselian interval, the most represented heavy minerals are rutile, zircon, tourmaline, titanite, apatite, and pyrite. The above can be further classified into three types of associations: HMA-III , HMA-IV, and HMA-V. The average ZTR index in this interval shows an increase from $35 \%$ to $73 \%$, indicating that the sediment was deposited in an increasingly distal area, and detrital material from different provenance areas was mixed.

In the Sakmarian stage, the northern EMA showed an increase in titanite content in wells $\mathrm{H} 4$, Y521, Y787, Y653, G3, and Y432, and the average grain size of heavy minerals increased from $0.01-0.15 \mathrm{~mm}$ to $0.02-0.03 \mathrm{~mm}$. The average ZTR index shows a decreasing trend, from $52 \%$ to $31 \%$ that, together with the above parameters suggest a more proximal source, possibly in the 
375

QOB affected by uplift at that period (Zhu et al., 2011; Dong et al., 2016).

\subsection{Trace element and REE patterns}

(1) Trace element and REE patterns

The chemical stability of $\mathrm{La}, \mathrm{Ce}, \mathrm{Nd}, \mathrm{Y}, \mathrm{Th}, \mathrm{Zr}, \mathrm{Hf}, \mathrm{Nb}, \mathrm{Ti}$, and $\mathrm{Sc}$ during sediment migration and the preservation in marine depositional environments of their concentration distribution acquired in continental systems allow tracking source areas. In this study, we used the Hf-La/Th, La-Sc-Co/Th, and $\Sigma$ REE-La/Yb indexes to identify the mineral composition of the source rock and their corresponding tectonic setting (FIG. 11). As shown by the $\mathrm{Hf}$ content ranging from 5.05 $\times 10^{-6}$ to $8.33 \times 10^{-6}$ and the La/Th ratio from 3.2 to 5.0 ., the lithology of the source rocks of the Bashkirian to Sakmarian deposits is mainly felsic (FIG. 11a). This is further attested by the Co/Th and La/Sc ratio of $0.47-1.93$ and $2.73-8.40$ respectively (FIG. 11b). The $\Sigma$ REE ranges from $187.17 \times 10^{-6}$ to $751.75 \times 10^{-6}$ and the $\mathrm{La} / \mathrm{Yb}$ ratio from 1.06 to 2.80 (FIG 11C). Finally, the La-ThSc, Th-Co-Zr/10 and Th-Sc-Zr/10 plots in FIGS. 11d-e suggest that the tectonic setting of the source area was intermediate between an active continental margin and island arc environment.

(2) Vertical evolution of the REE and trace element patterns in relation with sea-level fluctuation

The $\Sigma$ REE content of all analyzed samples ranges in $(187.17-751.75) \times 10^{-6}$, and its average value is $299.83 \times 10^{-6}$, which is slightly higher than that in North American Shale Composite (NASC $\left.\left(173.1 \times 10^{-6}\right)\right)$. ELREE ranges from $174.34 \times 10^{-6}$ to $669.06 \times 10^{-6}$, and $\Sigma$ HREE from $\left(12.84 \times 10^{-6}\right.$ to $82.69 \times 10^{-6} . \Sigma$ LREE/ $\Sigma$ HREE is $8.09-16.44$, and the average value is 11.44 , which is higher than that of NASC (7.50). The value of $(\mathrm{La} / \mathrm{Sm})_{\mathrm{N}}$ has a positive correlation with the fractionating degree of the LREE, whereas $(\mathrm{Gd} / \mathrm{Yb})_{\mathrm{N}}$ can reflect that of HREE. As McLennan et al. 
(1990) pointed out, an enrichment in LREE indicates a subaqueous setting; otherwise, HREE

398

showed an aquatic setting. From the Bashkirian to the Gzhelian, we interpret the increase in $\Sigma$ LREE/ $/$ HREE as indicative of a transgression phase. Similarly, the decrease in $\Sigma$ LREE/ $/ \mathrm{HREE}$ during the Asselian to the Sakmarian is interpreted as marine regression.

As mentioned above, the trace elements ratio can also serve as an index of sea level variations (Qiu et al., 2015). During the early Pennsylvanian, the $w(\mathrm{Sr}) / w(\mathrm{Ba})$ of samples $\mathrm{G} 3$, DJ43, and DJ53 is over 0.5 , and the $w(\mathrm{Ge}) / w(\mathrm{La})$ and $w(\mathrm{Rb}) / w(\mathrm{Zr})$ are over 1.5 and 0.75 , respectively, which indicated a marine setting in the responding area. The $w(\mathrm{Ge}) / w(\mathrm{La})$ and $w(\mathrm{Rb}) / w(\mathrm{Zr})$ of samples $\mathrm{H} 4$ and $\mathrm{Y} 787$ in the western EMA is less than 1.5 and 0.75 , which represent a continental setting. Thus, we speculate that the main transgression prograded westward.

During the Asselian stage, the $(\mathrm{Sr}) / w(\mathrm{Ba}), w(\mathrm{Ce}) / w(\mathrm{La})$, and $w(\mathrm{Rb}) / w(\mathrm{Zr})$ of $\mathrm{Y} 787$ showed a declining trend, whereas the $w(\mathrm{~V}) /(w(\mathrm{Ni})+w(\mathrm{~V}))$ and $\mathrm{w}(\mathrm{CaO}) / \mathrm{w}\left(\mathrm{MgO} \times \mathrm{Al}_{2} \mathrm{O}_{3}\right)$ indices increased to over 0.25 and 0.75 . These results indicate that the sea level rose sharply during the Asselian stage; this conclusion is the similar to that of Xin et al. (2018). During the Sakmarian, w(Sr)/w(Ba) in G3 decreased sharply to 0.2 , indicating a regression process in the southern EMA. Combining the trace element ratio and the study of Zhu et al. (2008), we infer that the main regression was ESE directed.

\section{$6.4 \delta^{18} \mathrm{O}$ and $\delta^{13} \mathrm{C}$ data}

The $\delta^{18} \mathrm{O}$ and $\delta^{13} \mathrm{C}$ data obtained on whole-rock samples show the fluctuation trend of the sea level caused by climate or the sediment rate change (FIG. 14). During the Pennsylvanian, $\delta^{13} \mathrm{C}_{\mathrm{V}}$. PDB ranged from $-8 \%$ to $-25 \%$, and $\delta^{18} \mathrm{O}_{\mathrm{V} \text {-PDB }}$ ranged from $-5 \%$ 。 to $-15 \%$. The value shows a 
negative excursion and a decreasing trend, indicating an warming climate and more rainfall. This

420

421

422

423

424

426

427

428

429

430

431

432

result is consistent with the study of Montanez et al. (2007) and Haq and Schutter (2008). During the Asselian-Sakmarian, $\delta^{13} \mathrm{C}_{\mathrm{V}-\mathrm{PDB}} \%$ o(-4.35\%॰--1.36\%。) and $\delta^{18} \mathrm{O}_{\mathrm{V}-\mathrm{PDB}} \%$ (-9.42--11.35) showed a positive excursion, which speculate the sea level rising during this interval.

\subsection{Paleontological assemblage}

During the Pennsylvanian, the value of $\mathrm{w}_{\text {leaf }}$ (the amount of preserved leaf in macro-plant remnants) showed a rising trend from 0.47 to 0.52 including species such as Cathaysiodendron nanpiaoense, Conchophyllum richthofenii, Alloiopteris sp., and Lepidodendron cf. szeianumis. In the early Pennsylvanian series, leaf remnants are generally fragmented and mixed with stems fragments (FIG. 15, samples G10 and DJ28). In the late Pennsylvanian, the $\mathrm{w}_{\text {leaf }}$ increased to 0.52, suggesting a rising sea level; whereas the large proportion of complete leaf remnants (FIG. $15 \mathrm{G} 7$ and H5) suggests a weakening hydrodynamic setting.

During the early Permian, the amount of plant fossils sharply increased, and the $w$ biomass of ferns such as Lycopsids, Emplectopteris, and Emplectopteridium, showed a sudden decrease during the transition from Kasimovian to Asselian. The root and stem fossils were predominant during the Asselian interval (FIG. 15 G1), and the ratio of the broad leaf remnants $\left(\mathrm{w}_{\text {leaf }}\right)$ decreased to 0.30. Up to the Sakmarian interval, the stem fragments keep predominant, whereas the $w_{\text {leaf }}$ declined to $22 \%$.

\subsection{Clay minerals distribution}

As indicated above, continental sediment generally show a high chlorite and/or kaolinite content while marine sediment may show a high illite content. Furthermore, Raucsik and Varga, (2008) and Chamley et al., (1993) showed that differential settling of clay minerals during 
sedimentation processes could explain the illite and smectite enrichment in marine settings away

442 from the major river deltas and estuaries Triangle diagrams showing the proportion of each type 443 of clay (chlorite and kaolinite are plotted on the same location) are thus use to infer the 444 continental, shallow-marine or deep-marine depositional environment through time (FIG.16).

$445 \quad$ Northeastern part of the EMA: Wells DJ16 and DJ43 (FIG. 16) are characterized by a high 446 chlorite content $(>50 \%)$ in the Pennsylvanian, which shows an increasing in illite content 447 characterizing the late Pennsylvanian (Kasimovian), which rise from $20 \%$ to $45 \%$. whereas, 448 chlorite and kaolinite are still predominant ( $w_{\text {clay }}$ (the ratio of $w($ chlorite + kaolinite) $/ w(($ illite $))$ values 449 are still over 1.0), indicate that the sediments from a continental setting is dominated in this 450 interval. During the Asselian stage, the illite content of wells DJ16 and DJ43 decreased to 35\%, 451 further supporting the occurrence of a slight regression phase and an increasing input of 452 continent-derived detrital material.

Southeastern part of the EMA: In wells DJ53 and DJ30 illite dominated (their content high up to $50 \%$ ) during the Pennsylvanian to Sakmarian. All the above data indicate that the sediment deposited in the southern EMA may be below the sea level. content $(>50 \%)$, and a $w_{\text {clay }}$ index over 1.5 , indicating that the southwestern part of the EMA is 458 below the sea level up to the late Pennsylvanian. With the illite content decreasing dramatically 459 (from $35 \%$ to $25 \%$ ), we infer that a regression progress occurred in the southwestern block during 460 the early Permian.

$461 \quad$ Northwestern part of the EMA: In well H4, chlorite and kaolinite dominate the clay spectrum 462 from the Pennsylvanian to the Sakmarian, indicating a terrestrial depositional setting. As to the 
Asselian-Sakmarian, the chlorite content in Y787 shows a decreasing trend (from $65 \%$ to $50 \%$ ),

464 indicating less sediment input from continental source regions.

\section{Provenance area identification and sediment supply calculation}

\subsection{Provenance}

\subsubsection{Provenance area during the Pennsylvanian}

Based on published U-Pb data from Yang et al. (2005), Darby and Gehrels (2006), Li et al. (2013), and Sun et al. (2014) we obtained the main characteristics of potential provenance areas

in the Qinling orogenic belt (south), the Qaidam-Qilian orogenic belt (west) and the Yinshan orogenic belt (north)(FIG. 8). Furthermore, Xie and Heller (2013) pointed out that late Paleozoic uplift in the north China block may also be a potential source area for the Ordos basin. The age spectrum of JC-A and JC-B (early Pennsylvanian) show a major zircon U-Pb age population at peak point at $1750 \mathrm{Ma}$, we speculate that some sediment came from the Yinshan orogenic belt.

According to FIG. $11 \boldsymbol{d}$ and $\boldsymbol{f}$, the trace elements pattern of the early Pennsylvanian samples suggest a source mainly composed of continental island arc and active continental margin 478 lithologies, again suggesting a source in the Qaidam-Qilian and Yinshan orogenic belts (Darby and Gehrels,2006); Golonka and Ford, 2000). Finally, both HMA (samples DJ43 and DJ53) and 480 ZTR indexes indicate a distal deposition process compatible with a source in the Qilian Shan and 481 Yinshan (FIG. 10). 
belts (Sun et al., 2014; Xin et al., 2018). Furthermore, Zhu et al., 2011 and Dong et al., 2016,

indicated a source from the Qinling orogenic belt in the early Permian southern EMA deposits.

Trace elements and REE patterns further indicate that the material was largely derived from

Paleozoic sedimentary rock or igneous rock (as Sample E shown in FIG. 12) (Shi et al., 2018).

Thus, we speculate that some of the early Permian sediment originated from the Qinling region.

The Asselian record of wells H5 and DJ53 show two other zircon U-Pb age peaks at 1650-2300

and 2300-2500 Ma. Based on the analogy with the age spectrum obtained by Darby and

Gehrels(2006)we infer that some of the material also derived from the Yinshan orogenic belt. The increase observed in the ZTR index support that hypothesis of a more distal source.

In the Sakmarian stage, these two zircon U-Pb age peaks are absent from the age spectrum

(FIG. 8), especially for the wells in the southern EMA (G2). Based on the HMA index (FIG. 10),

we speculate that the provenance area of the sediment in the northern EDM is mainly the

ZTR index indicates a switch from distal provenance to a more proximal source. Moreover, the

issued from the Yinshan and Qinling orogenic belt.

\subsection{Sediment supply rate calculation}

We selected two profiles to calculate the sediment deposition rate in the EMA. FIGS. 17 and

$$
\text { Pt10), and Lower Shanxi Formation (Pt10-Ps1). }
$$


As shown in the well calibration (FIG. 1), the Moscovian-Kasimovian stage in the early

508 Pennsylvanian is represented by the Penzi Formation, while the Taiyuan Formation formed 509 during the Gzhelian stage.

510 Then, we evaluated the strata thickness (A) on the basis of the seismic profile in FIGS. 17 and

511 18. During the Moscovian-Kasimovian stage (315.2 303Ma), the sediment from the eastern EMA

512 was deposited, and its transport path showed a east direction as that in FIG. 18. The statistical

513 mean thickness of the strata $(A)$ in a series of the $E-W$ direction profiles range from $70 \mathrm{~m}$ to $90 \mathrm{~m}$.

514 Thus, the average sedimentation rate at this stage is $8 \mathrm{~m} / \mathrm{Ma}$, whereas the minimum 515 sedimentation rate is $5 \mathrm{~m} / \mathrm{Ma}$. During the Gzhelian stage, the decrease in the strata thickness to $516 \quad 10-20 \mathrm{~m}$ corresponds to a declining trend of the sedimentation rate $(2 \sim 4 \mathrm{~m} / \mathrm{Ma})$ interval. The low 517 sedimentation rate in the Gzhelian (Jiang and Wang, 2012; Xu et al., 2015) is directly related to 518 the formation of the carbonate platform in the EMA, as the clastic input largely decreased.

The Asselian stage is represented by the Lower Shanxi Formation, and the Sakmarian by the

We selected a seismic profile in the $2 \mathrm{D}$ block, consistent with the sediment migration direction.

523 According to the above study, sediment was mainly transported from the northern EMA during the

524 Asselian stage (FIG. 17). During the Sakmarian, sediment was transported from two directions:

525 the southern EMA was filled by proximal material from QOB(Qiling Orogenic belt), whereas the northern block was filled sediment from a distal area(YOB: Yinshan Orogenic belt). Thus, as the

527 static data in Table 3, we evaluate the sedimentation rate in the southern EMA and calculated the 
As shown in FIG. 18, the average strata thickness (A) of the Lower Shanxi Formation

530 (Asselian298 295Ma) is $80-100 \mathrm{~m}$, and the calculated sedimentation rate is $20-25 \mathrm{~m} / \mathrm{Ma}$. In the

531 Upper Shanxi Formation (Sakmarian), more sediment were provided and the sedimentation rate reached $30 \mathrm{~m} / \mathrm{Ma}$ in the southern block and 20 25 m/Ma in the north E.M.D. .

\subsection{Transgression/regression rate calculation}

As shown in FIGS.16a and 16b, the main transgression/regression direction during the

Pennsylvanian is $\mathrm{E}-\mathrm{W}$ in the northern block, whereas that in the southern block is $\mathrm{N}-\mathrm{NW}$.

537

538

539 from TP1 to TP3, the transgression rate on the southern block during the Pennsylvanian period was $7.6 \mathrm{~km} / \mathrm{Ma}$. Trace elements, $\delta^{18} \mathrm{O}$ and $\delta^{13} \mathrm{C}$, and paleontological assemblages show a sharp

\section{7} the resolution of the seismic profile makes it impossible to calculate the regression rate during that period.

According to the profiles with a similar direction of transgression/regression as that of the northern block, the seismic packages (TP9-TP10) in FIG. 18 are characterized by high continuity and low onlap. These characteristics indicate limited erosion during the sea level rising process. Jiang and Wang. (2012) and $\mathrm{Xu}$ et al. (2015) suggested that the transgression process in the Pennsylvanian was mainly controlled by accommodation changes. The average transgression rate during the Pennsylvanian was $15 \mathrm{~km} / \mathrm{Ma}$ (T.P.1 4 and 8 10 TABLE 3). As to the southern block, the seismic packages showed an onlap from TP1 to TP3, indicating that the regional subsidence provided enough accommodation space for the sediment. Considering the distance regression event during the late Pennsylvanian (Kasimovian) (FIGS. 13, 14, and 15). However, that period. 
FIG. 18 to calculate the transgression rate. The TP13 and TP14 markers were chartered by a series of discontinuous seismic packages and distinct concave reflection boundaries. We

554 calculated the average transgression of the EMA as $30 \mathrm{~km} / \mathrm{Ma}$. During the Sakmarian stage (FIG. $\mathbf{1 6 d )}$, sea level variations occurred in a spatially variable pattern caused by the uplifting process

\section{6} in the southern orogenic belt. More proximal sedimentation lead to a sharp regression in the southern EMA. According to the seismic packages RP4, RP5, and RP6 (FIG .17), we obtained a regression rate of $50 \mathrm{~km} / \mathrm{Ma}$. In the northern block, the calculated average regression rate ranges from $15 \mathrm{~km} / \mathrm{Ma}$ to $20 \mathrm{~km} / \mathrm{Ma}$ according to the seismic packages RP9 and RP10 (TABLE 3).

\section{Mechanism of transgression or regression in intracratonic basin}

After calculating the sedimentation rates and the transgression/regression rates, we reconstructed the S2S system during the Carboniferous-Permian (FIG. 19) in accordance with the BQART model of Syvitski and Milliman (2007). (FIG. 20) and classified it into three types: lowtransgression rate and less-sediment supply S2S pattern (LT-LS) during the Pennsylvanian period, high-transgression rate and massive sediment supply S2S pattern (HT-MS), and lowtransgression rate and massive sediment supply S2S pattern (LT-MS) during the Asselian to Sakmarian stage. Below, we infer the mechanism of Carboniferous-Permian transgression in accordance with the quantitative parameters of the S2S system.

\subsection{S2S distribution pattern between the interglacial and glacial epochs}

During the early Pennsylvanian (Bashkirian-Kasimovian), the EMA mainly developed tidal deposits. We distinguished the N-S directed tidal barriers, which developed on the former basement (Shen et al.,2017), separating the EMA from the western part of the Ordos Basin (both 
sub-basins were evolving independently). In addition, the provenance study shows that the

574 sediment came from a distal area in the western margin (FIG. 19c). Combining the above

575 depositional setting, meandering channels in the western block and tidal channels in the eastern

576 EMA (FIG. 19a). With the decrease in sedimentation rate and the increasing transgression area,

577 the carbonate platform developed during the late Pennsylvanian period (Gzhelian) along the

578 western EMA; the lithofacies also support this conclusion. Thus, we infer that the shallow-marine

579 areas in the early stage. At the same period, the western sub-basin is characterized by floodplain

580 and channel deposits (Zhang et al. 1997) associated a low-transgression rate and less-sediment

581 supply (LT-LS S2S pattern) (FIG. 20a). Then, refer to the study of (Michael et al.,

582 2013;Hampson et al., 2014), this pattern of S2S system further shows mass sediment attested

583 by fine-grained deposits infills.

584 During the Asselian stage, the depositional setting constrained from seismic data shows a

585

586

587

588

589

590

591

592

material. We distinguished facies associations LFA.1 and LFA.3 during this interval and interpret

593 it as a meandering channel. The S2S system that developed in the northern EMA had an HT-MS

594 pattern. By contrast, the southern block developed various S2S systems. From the facies 
association (FIG. 4), we conclude that delta fan or coarse-grained delta depositional

596

environments dominated during this interval. Thus, we infer that the Asselian-Sakmarian stage

597

with massive sediment input corresponds to the interglacial period. The S2S system in the 598 southern block shows a typical low-transgression rate and massive sediment supply (LT-MS) S2S pattern (FIG. 21c). In the southern block, coarse-grained submarine fans or delta fans 600 developed in proximal areas. In the northern EMA, sedimentation occurred with more distal than 601 the southern one..

\subsection{Mechanism of transgression from the perspective of the S2S system}

603

Based on the depositional environments (FIG. 19) and reconstruction of the topography of the basin derived from seismic data (FIG. 17 and 18), we propose the following S2S pattern model.

The topographic reconstruction of the Pennsylvanian basin indicates low continental slopes.

The stratigraphy indicates a limited carbonate platform and shallow waters characterized by tidal-

608 influenced deposits. Then, we calculated the parameters (TABLE 3) of the LT-LS S2S pattern 609 during the Pennsylvanian and built the response equations as follows:

$$
V=a A+b S+c \alpha \cdot e^{H}+m
$$
where $V$ is the volume of the S2S system, which can be obtained from the seismic data; $A$ is

612 the distance between the provenance area and the sink area; $\mathrm{S}$ represents the sedimentation 613 rate; $\alpha$ shows the dip angle of the slope; and $H$ is the relative sea level. $a, b$, and $c$ in the 614 equation are obtained in accordance with the fitting of the data in TABLE 3.

615 As stated above, the volume of the S2S system during the Pennsylvanian is limited, and most 616 sediment accumulated on the slope (FIG. 20a). The bubble chart shows that $\alpha$ is inversely 
proportional to the relative sea level $(\mathrm{H})$. We infer that the key factor controlling the relative sea $(\mathrm{H})$

618 level is the variations in slope dip (a). Lan et al. (2016) also pointed out that the spatial variability

619 transgression direction is caused by topographic variations. On this basis, as the general slope

620 (shown as the morphology map in FIG.16), we can explain the fast transgression in the northern

621 EMA and the slow transgression rate in the southern block.

622

2 ) HT/LT-MS S2S pattern

623

The facies association pattern in FIG. 19 shows a spatially varible evolution in the south and

624

north block of the EMA during the Asselian-Sakmarian. As to the northern part, the stratigraphy

625

indicates braided channels or meandering/anastomosed rivers. The southern part was dominated

626

by fan deltas or alluvial fans. Then, we statistically calculated the S2S parameters in the

627

628

629

630

631

632

633

634

635

636

637

638

Asselian-Sakmarian (TABLE 3) and obtained the following fitting equation:

$$
V=a \alpha \cdot A \cdot H+b e^{s}+m \text {. }
$$

In the HT-MS system, the volume of the S2S system is affected by the sedimentary supply (S) and the relative sea level $(\mathrm{H})$. For the Sakmarian interval, we assumed that $\mathrm{V}$ is a determined value. The relative sea level $(H)$ is inversely proportional to the sedimentary supply (S). Furthermore, Zhu et al., (2008) pointed the subsidence rate keep stable during this interval. Thus, we speculate that in the HT-MS system the sedimentation rate is the key factor driving the sea level.

As to the LT-MS system in the southern block, we statistically calculated the S2S parameters during the Sakmarian and obtained

$$
V=a \alpha \cdot A \cdot H \cdot S+m .
$$

The bubble chart in FIG. $20 \mathrm{f}$ shows that the accumulated sediment and the dip angle can 
affect sea-level fluctuation as generally inferred in sequence stratigraphy studies (Zhu et al.,

640 2008). Due to the uplift caused by the formation of the Qinling orogenic belt, the slow

641 transgression rate, and the fast regression rate during the Sakmarian were mainly controlled by

642 the substantial amount of sediment accumulated and the increase in dip angle.

\section{9. Conclusion}

644 1. During the Pennsylvanian, sediments mostly came from the Qaidam-Qilian orogenic belt 645 and were deposited in a distal setting. Some distal sediments from the northern margin of the

646 Ordos Basin were injected in the dispersal area. The sediment accumulation rate during this

647 interval ranges from $5 \mathrm{~m} / \mathrm{Ma}$ to $10 \mathrm{~m} / \mathrm{Ma}$. During the Asselian-Sakmarian interval, material was

648 derived from multiple provenance areas. The sediment from the Qinling orogenic belt

649 accumulated at a rate of $30 \mathrm{~m} / \mathrm{Ma}$, and that from the western and northern Ordos Basin

650 accumulated at 10 and $30 \mathrm{~m} / \mathrm{Ma}$, respectively. The timing of sedimentation rate changes is 651 synchronous with the interglacial-glacial process in the early Permian.

652 2. During the early Pennsylvanian, transgression occurred towards the NEE, and the relative

653 horizonal transgression rate reached as high as $15 \mathrm{~km} / \mathrm{Ma}$. We classified this kind of S2S pattern

654 as LT-LS. During the Asselian stage, transgression occurred toward the NNW with a rate of 30

$655 \mathrm{~km} / \mathrm{Ma}$. During the Sakmarian, the sea level rose again, and the direction of transgression in the

656 EMA was NW. The transgression rate was up to $50 \mathrm{~km} / \mathrm{Ma}$. We also identified two different S2S

657 patterns, that is, LT-MS in the south and HT-MS in the north.

658 3. In the LT-LS pattern, the transgression/regression process was dominated by the dip angle

659 of the morphology due to lower sediment supply during the glacial period (Pennsylvanian). In this

660 pattern, the intensive reworking flow determined the region where coarse-grained sediments 
661

662

663

664

665

666

667

668

669

670

671

672

\section{Figure Captions}

674 FIG. 1

675

676

677

678

679

680

681 process. Shihhotse Formation.

\section{FIG. 2}

developed. As the S2S pattern transitions to the HT-MS or the LT-MS pattern, we speculate that

the migration of the sediment distance is a key factor that influences the transgression/regression

\section{Acknowledgments}

This research was sponsored by the Major State Science and Technology Research Program and China Scholarship Council (CSC) (No. 201906400071). The authors wish to thank the coalbed methane company, China National Petroleum Company, for providing the geological and seismic data used in this work. We also wish to acknowledge the Paleo-2D team of Université de Rennes 1, France, and the sedimentology team of the China University of Geoscience, Beijing. The authors also thank the journal reviewer and handling editor for their thoughtful and useful comments, which helped to improve the quality of this manuscript.

Geomorphological map of the North China Block. a. Faults developed in the Ordos Basin. The area with the dotted line is the EMA in the Ordos Basin. The generalized stratigraphic column is shown in the left. Seismic data calibration and the stratigraphic maker referred to the study of Zhu et al. (2008). From bottom to top: Penci Formation, Taiyuan Formation, Shanxi Formation, and

The stratigraphy developed in Y787, DJ53, DJ43, H4, and G3. From left to right of each well is 682 the Grammy curve, lithology. With the zircon age data shown in DJ53 and the related reference 
(Sun et al., 2014; Sun et al., 2013; Wang et al., 2003), we identified the deposited age of layers,

684 including the Penzi Fm. Taiyuan Fm, Lower Shanxi Fm. and Upper Shanxi Fm. Litho.=Lithology,

685 Chronolo.=Geochronology.

$686 \quad$ FIG. 3

687 Lithofacies templates. Seven kinds of lithofacies associations are provided on the right side.

688 From left to right: slow-rate one-directional traction flow deposited; high-rate one-directional

689 tractional flow, slow-rate bidirectional traction flow, mass flow deposited, static water deposited

690 and carbonated plate deposited.

$691 \quad$ FIG. 4

692 From left to right shows the seismic profile, well log of G6 and their responding cumulative 693 grain-size curve. We interpreted the lithofacies according to the core sample calibration. The 694 sandstone can be identified by the low GR value, while the limestone is characterized by the low 695 DEN value. Furthermore, integrated the well log and the seismic reflection, we interpreted the 696 facies association in the Pennsylvanian, including the tidal channel and the barriers.

$697 \quad$ FIG. 5

698 From left to right shows the seismic profile, well log of DJ12 and their responding cumulative

699 grain-size curve. The cross-bedding in LFA.1 and LFA.2 indicated a tractional flow developed.

700 Calibrated these on the seismic data, we recognized a series of the erosion channel developed.

$701 \quad$ FIG. 6

702 Representative zircon CL images. The small white circles represent the sites of $\mathrm{U}-\mathrm{Pb}$ age 703 analyses, and the measured ages are shown in Ma.

$704 \quad$ FIG. 7 
Data influenced by $\mathrm{Pb}$ loss and inclusion are deleted. Only analyses with concordances of $>90 \%$ are included in the combined probability density plot and histogram and discussed in the 708 subsequent sections.

FIG. 8

Zircon U-Pb age spectra of the Paleocene sediment in JC-A, JC-B, H5, DJ53, DJ51, and G2.

Potential source area: Qinling orogenic belt, Qaidam-Qilian orogenic belt, Yinshan orogenic belt, et al., 2011).

FIG. 9

As Hoskin and Black (2000) and Teipel et al. (2004) pointed out the according to the ratio of

Th/U value, we can infer the sediment are mainly provided by the igneous sources $(\mathrm{Th} / \mathrm{U}$ over ratio and age distribution. From left to right: samples of the Bashirian-Gzhelian, Asselian, and Samarian stages.

FIG. 10

HMA of Y521, H4, Y787, Y653, G3, Y432, DJ43, and DJ53. We classified the HMA into five types: rutile-prominent (rutile $>60 \%$ ), pyrite-prominent (pyrite $>60 \%$ ), titanite-prominent (titanite $>50 \%$ ), tourmaline-prominent (tourmaline $>30 \%$ ), and zircon-prominent (zircon $>30 \%$ ) 
Points in the source rock discrimination chart show the tectonic setting of the EMA sediment. left to right shows the La-Th-Sc, Th-Co-Zr, and Th-Sc-Zr.

730

731

732

733

734

735

736

737

738

739

740

741

742

743

744

745

746

747

FIG. 12

(a) Geological map of the Ordos Basin. We selected samples A, B, C, D, E, F, and G (b) around the EMA to study their clay mineral distribution. (c) represents the REE distribution in the Pennsylvanian with data from DJ28, DJ43, and DJ53. LLREE/ HREE is 8.09-16.44/11.44; (d) and (c) are the REE distribution in the Asselian and Sakmarian, respectively. We obtained the value of $\Sigma$ LREE/ $\Sigma$ HREE in the Asselian is $9.74-15.72 / 10.12$, whereas its value in the Sakmarian is $8.01-11.62 / 9.12$. These values indicate the regression process during the Asselian and

\section{Sakmarian.}

FIG. 13

Trace element vertical distribution in G3, H4, DJ43, DJ53, and Y787.

FIG. 14

$\delta^{18} \mathrm{O}$ and $\delta^{13} \mathrm{C}$ data vertical distribution in Y787, DJ53, DJ 43, H4, and G3.

FIG. 15

$$
\text { Column from left to right show the } \mathrm{w}_{\text {leaf }} \text { index, } \mathrm{w}_{\text {biomass }} \text { index, micropaleontological assemblage }
$$
(Pfefferkorn and Wang, 2007), and the plant fossils in the core samples. Referring to the statistical data of paleontological assemblage, we found that the sea level of the EMA increased during the Pennsylvanian and declined sharply during the Asselian-Sakmarian.

FIG. 16

$$
\text { We built the paleomorphology on the basis of 2D seismic data and the relative sea level as the }
$$


$w_{\text {clay }}$ index. From bottom to top: paleo-sea level developed from the early Pennsylvanian (a), the

750 late Pennsylvanian (b), the Asselian (c), and the Sakmarian (d).

751

752

753

754

755

756

757

758

759

760

761

762

763

764

765

766

767

768

769

770

FIG. 17

The seismic profile in the N-S direction and the location is shown in FIG. 1. We distinguished a series of tidal channel with the swing channels as the concave of the seismic event. As to the late Pennsylvanian (Gzhelian), the limestone developed and showed a continuous and high amplitude reflection. Referring to Zecchin et al. (2008), we distinguished a series of forest seismic packages and numbered them as TP1 to RP6.

FIG. 18

The seismic profile in the W-E direction and the location is shown in FIG. 1. We distinguished a series of forest seismic packages and numbered them as TP8 to RP10.

FIG. 19

(a) to (c) show the patterns of the three stages of the S2S system evolution during the Pennsylvanian and Asselian to Sakmarian. During the first stage, sediment migrated from a distal area, and a barrier developed on the slope. With the provenance area transfer, the north Yinshan orogenic provided mass sediment in this interval. During the third stage, the Qinling orogenic belt formed and lead delta fan developed in the southern block. We classified the S2S system of the first stage as a low-transgression-rate and less-sediment-supply S2S pattern. The second stage and the sediment rounding system in the northern block during the third stage has a hightransgression-rate and mass-sediment-supply S2S pattern, whereas the southern block in the third stage has a low-transgression-rate and mass-sediment-supply S2S pattern.

\section{FIG. 20}


772 sediment supply and the relative sea level. Then, we fit these parameters (in TABLE 3) and

773 obtained the balloon chart ( $d$ to $\mathrm{f}$ ). The diameter represents the volume of the S2S system, and

774 we can speculate the mechanism for the transgression/regression process in accordance with the

775 fitting equation.

\section{Table Caption}

777 Table 1

778 Facies association descriptions.

\section{$779 \quad$ Table 2}

780 Heavy mineral assemblage in the potential source.

\section{$781 \quad$ Table 3}

Parameters of the S2S system. Statistical data were based on seismic data. We obtained the dip angle with the slope dip along the slope.

\section{4} 32(4): 553-566.

\section{Reference}

Adkins, J.F., McIntyre, K. and Schrag, D.P., 2002. The salinity, temperature, and delta180 of the glacial deep ocean. Science, 298(5599): 1769-73.

Alkmim, F.F. and Martins-Neto, M.A., 2012. Proterozoic first-order sedimentary sequences of the São Francisco craton, eastern Brazil. Marine and Petroleum Geology, 33(1): 127-139.

Andrew, M., 1985. A new approach to provenance studies: electron microprobe analysis of detrital garnets from Middle Jurassic sandstones of the northern North Sea. Sedimentology,

Anees, A., Shi, W., Ashraf, U. and Xu, Q., 2019. Channel identification using 3D seismic 
attributes and well logging in lower Shihezi Formation of Hangjinqi area, northern Ordos Basin,

794

795

796

797

798

799

800

801

802

803

804

805

806

807

808

809

810

811

812

813

814

China. Journal of Applied Geophysics, 163: 139-150.

Bacon, K.L., Haworth, M., Conroy, E. and McElwain, J.C., 2016. Can atmospheric composition influence plant fossil preservation potential via changes in leaf mass per area? A new hypothesis based on simulated palaeoatmosphere experiments. Palaeogeography, Palaeoclimatology, Palaeoecology, 464: 51-64.

Blum, M.D. and Törnqvist, T.E., 2000. Fluvial responses to climate and sea-level change: a review and look forward. Sedimentology, 47: 2-48.

Bumby, A.J., Eriksson, P.G., Catuneanu, O., Nelson, D.R. and Rigby, M.J., 2012. MesoArchaean and Palaeo-Proterozoic sedimentary sequence stratigraphy of the Kaapvaal Craton. Marine and Petroleum Geology, 33(1): 92-116.

Chamley, H., Angelier, J. and Teng, L.S., 1993. Tectonic and environmental control of the clay mineral sedimentation in the late Cenozoic orogen of Taiwan. Geodinamica Acta, 6(2): 135-147.

Chen, Q., W. Li, H. Liu, K. Li, J. Pang, Y. Guo, and Z. Yuan, 2009, Provenance analysis of sandstone of the Upper Carboniferous to Middle Permian in Ordos basin. Journal of Palaeogeography, with English abstract, 11(6): 629-640.

Cheng, C., S. Li, X. Xie, T. Cao, W. L. Manger, and A. B. Busbey, 2019. Permian carbon isotope and clay mineral records from the Xikou section, Zhen'an, Shaanxi Province, central China: Climatological implications for the easternmost Paleo-Tethys. Palaeogeography, Palaeoclimatology, Palaeoecology, 514: 407-422.

Darby, B.J. and Gehrels, G., 2006. Detrital zircon reference for the North China block. Journal of Asian Earth Sciences, 26(6): 637-648. 
816 and R. Tonielli, 2015. Sorted bedforms over transgressive deposits along the continental shelf of 817 western Sardinia (Mediterranean Sea). Marine Geology, 359: 75-88.

818 Dong, Y., Z. Yang, X. Liu, S. Sun, W. Li, B. Cheng, F. Zhang, X. Zhang, D. He, and G. Zhang, 819 2016, Mesozoic intracontinental orogeny in the Qinling Mountains, central China: Gondwana 820 Research, 30: 144-158.

821

Du, J., S. Zhang, W. Xiao, and W. Jiang, 2017, Geochemistry Characteristics of Middle-

Lower Jurassic Clastic Rocks in the Northern Margin of Qaidan Basin and Their Geological

Significance: Journal of Earth Sciences and Environment, with English abstract, 39(06): 721-734.

826

Piotrowski, 2012. Evolution of Ocean Temperature and Ice Volume Through the Mid-Pleistocene transgression and its corresponding channel transformation pattern: A case study of the patterns, and pathway formation in Liaoxi Sag, Liaodong Bay Depression, North China: Evolution 

paleocurrent analysis. Palaios, 19(6): 587-597.

Gee, C.T., 2005. The genesis of mass carpological deposits (bedload carpodeposits) in the

842 Tertiary of the Lower Rhine Basin, Germany. Palaios, 20(5): 463-478.

Golonka, J. and Ford, D., 2000. Pangean (late Carboniferous-Middle Jurassic)

844 paleoenvironment and lithofacies. Palaeogeography, Palaeoclimatology, Palaeoecology, 845 161(1-2): 1-34.Haq, B.U. and Schutter, S.R., 2008. A chronology of Paleozoic sea-level changes. 846 Science, 322(5898): 64-68.

Haq, B.U., Hardenbol, J. and Vail, P.R., 1987. Chronology of fluctuating sea levels since the 848 Triassic. Science, 235(4793): 1156-1167.

Hilton, J. and Cleal, C.J., 2007. The relationship between Euramerican and Cathaysian 850 tropical floras in the Late Palaeozoic: Palaeobiogeographical and palaeogeographical 851 implications. Earth-Science Reviews, 85(3-4): 85-116.

853 Mckellar, 2009. Sequence stratigraphy of Jurassic strata in the lower Surat Basin succession, 854 Queensland. Australian Journal of Earth Sciences, 56(3): 461-476. Hoskin, P. and Black, L.P., 2000. Metamorphic zircon formation by solid-state 856 recrystallization of protolith igneous zircon. Journal of metamorphic Geology, 18(4): 423-439. Ichaso, A.A. and Dalrymple, R.W., 2009. Tide- and wave-generated fluid mud deposits in the 858 Tilje Formation (Jurassic), offshore Norway. Geology, 37(6): 539-542. 
Jiang, Z., Xu, J. and Wang, G., 2012. The discovery and significance of a sedimentary hiatus

860

861

862

863

864

865

866

867

868

869

870

871

872

873

874

875

876

877

880

878 Lan, C., Yang, M. and Zhang, Y., 2016. Impact of sequence stratigraphy, depositional facies 879 and diagenesis on reservoir quality: A case study on the Pennsylvanian Taiyuan sandstones,

within the Carboniferous Taiyuan Formation, northeastern Ordos Basin, China. AAPG Bulletin, 96(7): 1173-1195.

Kemp, D.B. and Izumi, K., 2014. Multiproxy geochemical analysis of a Panthalassic margin record of the early Toarcian oceanic anoxic event (Toyora area, Japan). Palaeogeography, Palaeoclimatology, Palaeoecology, 414: 332-341.

Klein, G.D., 1982. Probable sequential arrangement of depositional systems on cratons. Geology, 10(1): 17.

Koch, J.T. and Frank, T.D., 2011. The Pennsylvanian-Permian transition in the low-latitude carbonate record and the onset of major Gondwanan glaciation. Palaeogeography, Palaeoclimatology, Palaeoecology, 308(3-4): 362-372.

Kröner, A., S. A. Wilde, G. C. Zhao, P. J. O Brien, M. Sun, D. Y. Liu, Y. S. Wan, S. W. Liu, and J. H. Guo, 2006. Zircon geochronology and metamorphic evolution of mafic dykes in the Hengshan Complex of northern China: Evidence for late Palaeoproterozoic extension and subsequent high-pressure metamorphism in the North China Craton. Precambrian Research, 146(1-2): 45-67.

Labaune, C., Tesson, M. and Gensous, B., 2008. Variability of the transgressive stacking pattern under environmental changes control: Example from the Post-Glacial deposits of the Gulf of Lions inner-shelf, Mediterranean, France. Continental Shelf Research, 28(9): 1138-1152. northeastern Ordos Basin, China. Marine and Petroleum Geology, 69: 216-230. 
Li, S., Wilde, S.A., Wang, T. and Guo, Q., 2013. Incremental growth and origin of the

882 Cretaceous Renjiayingzi pluton, southern Inner Mongolia, China: Evidence from structure, 883 geochemistry and geochronology. Journal of Asian Earth Sciences, 75: 226-242.

Sciences, 111: 528-552.

893

Martins-Neto, M.A., Pedrosa-Soares, A.C. and Lima, S.A.D.A., 2001. Tectono-sedimentary evolution of sedimentary basins from Late Paleoproterozoic to Late Neoproterozoic in the Sao Francisco craton and Araçua fold belt, eastern Brazil. Sedimentary Geology, 141: 343-370. sequence stratigraphy of a mixed carbonate-siliciclastic, cratonic ramp (Upper Ordovician; Kentucky-Ohio, USA): insights into the relative influence of eustasy and tectonics through analysis of facies gradients. Palaeogeography, Palaeoclimatology, Palaeoecology, 210(2-4): 267-294.

901

McLennan, S.M., Taylor, S.R., McCulloch, M.T. and Maynard, J.B., 1990. Geochemical and $902 \mathrm{Nd}-\mathrm{Sr}$ isotopic composition of deep-sea turbidites: Crustal evolution and plate tectonic 
903

904

905

906

907

908

909

910

911

912

913

914

915

916

917

918

919

920

921

922

923

924

associations. Geochimica et Cosmochimica Acta, 54(7): 2015-2050.

Michael, N.A., Whittaker, A.C. and Allen, P.A., 2013. The Functioning of Sediment Routing Systems Using a Mass Balance Approach: Example from the Eocene of the Southern Pyrenees. The Journal of Geology, 121(6): 581-606.

Milne, G.A., Gehrels, W.R., Hughes, C.W. and Tamisiea, M.E., 2009. Identifying the causes of sea-level change. Nature Geoscience, 2(7): 471-478.

Montanez, I. P., N. J. Tabor, D. Niemeier, W. A. Dimichele, T. D. Frank, C. R. Fielding, J. L. Isbell, L. P. Birgenheier, and M. C. Rygel, 2007. CO2-forced climate and vegetation instability during Late Paleozoic deglaciation. Science, 315(5808): 87-91.

Morton, A.C. and Hallsworth, C., 1994. Identifying provenance-specific features of detrital heavy mineral assemblages in sandstones. Sedimentary Geology, 90(3): 241-256.

Nikishin, A. M., P. A. Ziegler, R. A. Stephenson, S. A. P. L. Cloetingh, A. V. Furne, P. A. Fokin, A. V. Ershov, S. N. Bolotov, M. V. Korotaev, A. S. Alekseev, V. I. Gorbachev, E. V. Shipilov, A. Lankreijer, E. Y. Bembinova, and I. V. Shalimov, 1996. Late Precambrian to Triassic history of the East European Craton: dynamics of sedimentary basin evolution. Tectonophysics, 268(1): 23-63. Pfefferkorn, H.W. and Wang, J., 2007. Early Permian coal-forming floras preserved as compressions from the Wuda District (Inner Mongolia, China). International Journal of Coal Geology, 69(1-2): 90-102.

Phillips, T.L. and Galtier, J., 2005. Evolutionary and ecological perspectives of Late Paleozoic ferns Part I. Zygopteridales. Review of Palaeobotany and Palynology, 135(3-4): 165-203.

Phillips, T.L. and Galtier, J., 2011. Evolutionary and ecological perspectives of late Paleozoic ferns Part II. The genus Ankyropteris and the Tedeleaceae. Review of Palaeobotany and 
925

926

927

928

929

930

931

932

933

934

935

936

937

938

939

940

941

942

943

944

945

946

Palynology, 164(1-2): 1-29.

Pratt, L.M., Phillips, T.L. and Dennison, J.M., 1978. Evidence of non-vascular land plants from the Early Silurian (Llandoverian) of Virginia, USA. Review of palaeobotany and palynology, 25(2): 121-149.

Pu, R., Zhu, L. and Zhong, H., 2009. 3-D seismic identification and characterization of ancient channel morphology. Journal of Earth Science, 20(5): 858-867.

Qin, C., 2002. The thickness of seismogenic layer under the areas surrounding the Ordos block, Northern China. Pure and Applied Geophysics, 159(11-12): 2613-2628.

Qiu, X., C. Liu, G. Mao, Y. Deng, F. Wang, and J. Wang, 2015a. Major, trace and platinumgroup element geochemistry of the Upper Triassic nonmarine hot shales in the Ordos basin, Central China. Applied Geochemistry, 53: 42-52.

Qiu, X., Liu, C., Wang, F., Deng, Y. and Mao, G., 2015b. Trace and rare earth element geochemistry of the Upper Triassic mudstones in the southern Ordos Basin, Central China. Geological Journal, 50(4): 399-413.

Raucsik, B. and Varga, A., 2008. Climato-environmental controls on clay mineralogy of the Hettangian-Bajocian successions of the Mecsek Mountains, Hungary: An evidence for extreme continental weathering during the early Toarcian oceanic anoxic event. Palaeogeography, Palaeoclimatology, Palaeoecology, 265(1-2): 1-13.

Ren, Z., S. Zhang, S. Gao, J. Cui, Y. Xiao, and H. Xiao, 2007, Tectonic thermal history and its significance on the formation of oil and gas accumulation and mineral deposit in Ordos Basin:

Science in China Series D: Earth Sciences, 50(S2): 27-38.

$$
\text { Rimmer, S.M., 2004. Geochemical paleoredox indicators in Devonian-Mississippian black }
$$


947

948

949

950

951

952

953

954

955

956

957

958

959

960

961

962

963

964

965

966

967

968

shales, Central Appalachian Basin (USA). Chemical Geology, 206(3-4): 373-391.

Ritts, B.D., Keele, D., Darby, B.J. and Liu, S., 2006. Ordos Basin Gas Reservoir Outcrop Analogs: Permian Braided Fluvial Sandstone of the Zhuozi Shan and Helan Shan, China. International Geology Review, 48(7): 573-584.

Ruppen, D. et al., 2014. Restoring the Silurian to Carboniferous northern active continental margin of the Mongol-Okhotsk Ocean in Mongolia: Hangay-Hentey accretionary wedge and seamount collision. Gondwana Research, 25(4): 1517-1534.

Shen, Y., Y. Qin, G. G. X. Wang, Y. Guo, J. Shen, J. Gu, Q. Xiao, T. Zhang, C. Zhang, and G. Tong, 2017. Sedimentary control on the formation of a multi-superimposed gas system in the development of key layers in the sequence framework. Marine and Petroleum Geology, 88: 268-281.

Shi, J., Wenhui, H., Chenhang, L. and Xiaonan, C., 2018. Geochemical characteristics and geological significance of the Upper Paleozoic mudstones from Linxing area in Ordos Basin. Acta Petrolei sinica, with English abstract, 8(39): 876-889.

Shi, J., Zeng, L., Zhao, X., Zhang, Y. and Wang, J., 2020. Characteristics of natural fractures in the upper Paleozoic coal-bearing strata in the southern Qinshui Basin, China: Implications for coalbed methane (CBM) development. Marine and Petroleum Geology, 113: 104152.

Sloss, L.L., 1963. Sequences in the cratonic interior of North America. Geological Society of America Bulletin, 74(2): 93-114.

Song, S., Su, L., Li, X., Niu, Y. and Zhang, L., 2012. Grenville-age orogenesis in the QaidamQilian block: The link between South China and Tarim. Precambrian Research, 220-221: 9-22. Stanley, S.M. and Powell, M.G., 2003. Depressed rates of origination and extinction during the 
969

970

971

972

973

974

975

976

977

978

979

980

981

982

983

984

985

986

987

988

989

990

late Paleozoic ice age: A new state for the global marine ecosystem. Geology, 31(10): 877.

Stollhofen, H., Stanistreet, I.G., Bangert, B. and Grill, H., 2000. Tuffs, tectonism and glacially related sea-level changes, Carboniferous-Permian, southern Namibia. Palaeogeography, Palaeoclimatology, Palaeoecology, 161(1-2): 127-150.

Sun, B., Zeng, F., Liu, C., Cui, X. and Wang, W., 2014. Constraints on U-Pb Dating of Detrial Zircon of the Maximum Depositional Age for Upper Paleozoic Coal-Bearing Strata in Xishan, Taiyuan and Its Stratigraphic Significance. Acta Geologica sinica-English Abstract, 2(88): 185197.

Syvitski, J.P.M. and Milliman, J.D., 2007. Geology, Geography, and Humans Battle for Dominance over the Delivery of Fluvial Sediment to the Coastal Ocean. The Journal of Geology, 115(1): 1-19.

Tabor, N.J. and Poulsen, C.J., 2008. Palaeoclimate across the Late Pennsylvanian-Early Permian tropical palaeolatitudes: A review of climate indicators, their distribution, and relation to palaeophysiographic climate factors. Palaeogeography, Palaeoclimatology, Palaeoecology, 268(3-4): 293-310.

Teipel, U., R. Eichhorn, G. Loth, J. Rohrmüller, R. Höll, and A. Kennedy, 2004, U-Pb SHRIMP and $\mathrm{Nd}$ isotopic data from the western Bohemian Massif (Bayerischer Wald, Germany): implications for upper Vendian and lower Ordovician magmatism: International Journal of Earth Sciences, 93(5): 782-801.

Wang, A. Q., D. B. Yang, H. T. Yang, M. S. Mu, Y. K. Quan, L. R. Hao, and W. L. Xu, 2019. Late Palaeozoic tectonic evolution of the southern North China Craton: Constraints from detrital zircon dating and $\mathrm{Hf}-\mathrm{O}$ isotopic compositions of the Benxi Formation, Sanmenxia area, North 
991

992

993

994

995

996

997

998

999

1000

1001

1002

1003

1004

1005

1006

1007

1008

1009

1010

1011

1012

China Craton. Geological Journal, 55(2): 1320-1331.

Wang, J., 2010. Late Paleozoic macrofloral assemblages from Weibei Coalfield, with reference to vegetational change through the Late Paleozoic Ice-age in the North China Block. International Journal of Coal Geology, 83(2-3): 292-317.

Wang, J., Feng, Z., Zhang, Y. and Wang, S., 2009. Confirmation of Sigillaria Brongniart as a coal-forming plant in Cathaysia: occurrence from an Early Permian autochthonous peat-forming flora in Inner Mongolia. Geological Journal, 44(4): 480-493.

Wang, Y., H. Li, L. Gu, C. Wu, D. Chai, P. Chen, S. Wang, and J. Zhang, 2003, Rb-Sr istope dating bauxite deposits in Shanxi Province: Acta Geoscientica Sinica, with English abstract, 6(24): 589-592.

Xie, X. and Heller, P.L., 2013. U-Pb detrital zircon geochronology and its implications: The early Late Triassic Yanchang Formation, south Ordos Basin, China. Journal of Asian Earth Sciences, 64: 86-98.

Xin, S., Y. Xinghe, P. Clift, L. Yalong, J. Lina, S. Dongxu, Y. DU, Z. Jinsong, and H. Xiaoqin, 2018. Sedimentology and Sequence Stratigraphy of Marine to Lacustrine Deltaic Deposits in a Craton Basin and Their Controlling Factors: Shan 2 Member-He 8 Member (GuadalupianLopingian, Permian), Southeast Ordos Basin, North China. Acta Geologica Sina-English Edition, 92(1): 268-285.

Xu, H., D. Tang, S. Tang, W. Zhang, Y. Meng, L. Gao, S. Xie, and J. Zhao, 2015. Geologic and hydrological controls on coal reservoir water production in marine coal-bearing strata: A case study of the Carboniferous Taiyuan Formation in the Liulin area, eastern Ordos Basin, China.

\section{Marine and Petroleum Geology, 59: 517-526.}


1014 lacustrine sandy debrites and turbidites in the lower Triassic Yanchang Formation, southeast 1015 Ordos Basin, central China: Facies distribution and reservoir quality. Marine and Petroleum 1016 Geology, 77: 1095-1107.

1017

Yang, H., Fu, J., Wei, X. and Liu, X., 2008. Sulige field in the Ordos Basin: Geological setting,

1019

1020

1021

1022

1023

1024

1025

1026

1027

1028

1029

1030

1031

1032

1033

1034 field discovery and tight gas reservoirs. Marine and Petroleum Geology, 25(4-5): 387-400.

Yang, R., Fan, A., Han, Z. and van Loon, A.J.T., 2017. Lithofacies and origin of the Late Triassic muddy gravity-flow deposits in the Ordos Basin, central China. Marine and Petroleum

Geology, 85: 194-219.

Yang, Y., Li, W. and Ma, L., 2005. Tectonic and stratigraphic controls of hydrocarbon systems in the Ordos basin: A multicycle cratonic basin in central China. AAPG bulletin, 89(2): 255-269.

Yin, S., Tian, T. and Wu, Z., 2019. Developmental characteristics and distribution law of fractures in a tight sandstone reservoir in a low-amplitude tectonic zone, eastern Ordos Basin, China. Geological Journal, 55(2): 1546-1562.

Yu, Q., Z. Ren, B. Wang, L. Gao, C. Li, and H. Cao, 2012, Thermal Evolution History of the Upper Paleozoic in Yanchang Exploratory Area, Ordos Basin: Geological Review, with English abstract, 58(2): 303-308.

Yuan, Y., S. Hu, H. Wang, and F. Sun, 2007, Meso-Cenozoic tectonothermal evolution of Ordos basin, central China: Insights from newly acquired vitrinite reflectance data and a revision of existing paleothermal indicator data: Journal of Geodynamics, 44(1-2): 33-46.

Zecchin, M., L. Baradello, G. Brancolini, F. Donda, F. Rizzetto, and L. Tosi, 2008. Sequence 
1035

1036

1037

1038

1039

1040

1041

1042

1043

1044

1045

1046

1047

1048

1049

1050

1051

1052

1053

1054

1055

1056

stratigraphy based on high-resolution seismic profiles in the late Pleistocene and Holocene deposits of the Venice area. Marine Geology, 253(3-4): 185-198.

Zhang, L., Bai, G., Luo, X., Ma, X., Chen, M., \& Wu, M., et al. (2009). Diagenetic history of tight sandstones and gas entrapment in the Yulin Gas Field in the central area of the Ordos Basin, China. Marine and Petroleum Geology, 26(6), 974-989.

Zhang, L., Sun, M., Wang, S. and Yu, X., 1998. The composition of shales from the Ordos basin, China: effects of source weathering and diagenesis. Sedimentary Geology, 116(1-2): 129-141.

Zhang, Z., Sun, K. and Yin, J., 1997. Sedimentology and sequence stratigraphy of the Shanxi Formation (Lower Permian) in the northwestern Ordos Basin, China: an alternative sequence model for fluvial strata. Sedimentary Geology, 112(1): 123-136.

Zhang, D., Yang, W., Qi, Y. and Yan, X., 2009. Analysis of the Material Source of Upper Paleozoic Shanxi Formation in Shenmu Region of Ordos basin. Natural Gas Geoscience, with English Abstract, 20(6): 901-906.

Zhu, H., Chen, K., Liu, K. and He, S., 2008. A sequence stratigraphic model for reservoir sandbody distribution in the Lower Permian Shanxi Formation in the Ordos Basin, northern China. Marine and Petroleum Geology, 25(8): 731-743.

Zhu, X., F. Chen, S. Li, Y. Yang, H. Nie, W. Siebel, and M. Zhai, 2011. Crustal evolution of the North Qinling terrain of the Qinling Orogen, China: Evidence from detrital zircon U-Pb ages and Hf isotopic composition. Gondwana Research, 20(1): 194-204.

Zou, C.N. et al., 2013. Continuous hydrocarbon accumulation over a large area as a distinguishing characteristic of unconventional petroleum: The Ordos Basin, North-Central China. 
1057 Earth-Science Reviews, 126: 358-369. 


\section{Facies Association}

LFA.1
Moderately to well sorting thick sandstone. There are thick

bad association trough crossing bedding. The thin layer of mudstone observed in the top.

Sb-Scm $(S c c)-M \quad$ Moderately sorted homogeneous sandstone. Regularly

lamellar crossing bedding in the top.

Strong rhythmic alteration of darker or lighter layers composed of fine-grained slit stone. The double-clay

cross-bedding in the upper part.

Gravel-supported conglomerate with regular imbedded layers. Upper to the top, matrix-supported conglomerate

shows an imbricated orientation

Moderately sorted fine stone in the bottom. Deformation structure occurs in the laminae. Despite intense bioturbation, there is no single trace identified.

Homogeneous carbonate with some mud clast identified in

\section{Inferred depositional environment}

Slow-rate flow deposited (Meandering channel environment)

(refer to Blum and Törnqvist (2009)

High-rate traction flow deposited (Braid channel environment)

Bidirectional slow-rate traction flow deposit(Tidal environment)

A static water setting (Swamp)(refer to /chaso and Dalrymple

Interchannel environment

Carbonate plate environment 
TABLE.2

\begin{tabular}{|c|c|c|c|c|c|c|c|c|c|c|c|c|c|}
\hline Period & $\begin{array}{c}\text { Potential } \\
\text { Source } \\
\text { Area }\end{array}$ & Zircon & Tourmaline & Rutile & Titanite & Garnet & IImenite & Apatite & Pyroxene & Pyrite & Spinel & $\begin{array}{l}\text { Types of } \\
\text { heavy mineral } \\
\text { assemblage }\end{array}$ & References \\
\hline Pennsylvanian & $\begin{array}{c}\text { Yishan } \\
\text { Orogenic } \\
\text { belt }\end{array}$ & 28.25 & 28.96 & 9.28 & 12.00 & & & 10.08 & & & 3.36 & $\begin{array}{l}\text { HMA-I Rutile } \\
\text { dominated }\end{array}$ & $\begin{array}{l}\text { Chen et al., } \\
2009\end{array}$ \\
\hline Pennsylvanian & $\begin{array}{l}\text { Qaidam- } \\
\text { Qilian } \\
\text { orogenic } \\
\text { belt }\end{array}$ & 9.08 & 0.04 & 0.15 & 0.01 & & & 7.96 & & 58.6 & & $\begin{array}{l}\text { HMA-II Pyrite } \\
\text { dominated }\end{array}$ & $\begin{array}{l}\text { Du et al., } \\
2017\end{array}$ \\
\hline Early Premarin & $\begin{array}{c}\text { Yishan } \\
\text { Orogenic } \\
\text { belt }\end{array}$ & 20.91 & 1.93 & 11.25 & 30.00 & & & 7.96 & & & & $\begin{array}{l}\text { HMA-IIITitanite } \\
\text { dominated }\end{array}$ & $\begin{array}{l}\text { Ruppen et } \\
\text { al., 2014; Li } \\
\text { et al., } 2014\end{array}$ \\
\hline Early Permian & $\begin{array}{c}\text { Yishan } \\
\text { Orogenic } \\
\text { belt }\end{array}$ & 10.96 & 36.15 & 3.94 & 7.02 & & & 0.99 & & & & $\begin{array}{l}\text { HMA-IV } \\
\text { Tourmaline } \\
\text { dominated }\end{array}$ & $\begin{array}{l}\text { Xin et al. } \\
2018\end{array}$ \\
\hline Early Permian & $\begin{array}{c}\text { Qiling } \\
\text { orogenic } \\
\text { belt }\end{array}$ & 43.42 & 5.74 & 11.48 & 16.86 & & 0.12 & & 0.12 & & 0.12 & $\begin{array}{l}\text { HMA-V Zircon } \\
\text { dominated }\end{array}$ & $\begin{array}{l}\text { Zhang et al., } \\
2009\end{array}$ \\
\hline
\end{tabular}




\begin{tabular}{|c|c|c|c|c|c|c|c|}
\hline$F m$. & Block & $\begin{array}{l}\text { Ave. Dip } \\
\text { Angle }\end{array}$ & Provenance Area & $\begin{array}{l}\text { Sink } \\
\text { Area }\end{array}$ & $\begin{array}{c}\text { Pathway Cut } \\
\text { Area } / \mathrm{km}^{2}\end{array}$ & $\begin{array}{c}\text { Uplift Evaluated } \\
\text { Height }\end{array}$ & $\begin{array}{c}\text { Average Transgression/Regression } \\
\text { Rate }\end{array}$ \\
\hline \multirow{7}{*}{ Penzi Formation } & T.P. 1 & 0.74 & 11.13 & 10.09 & 9.78 & 76.13 & 13.50 \\
\hline & T.P.2 & 0.94 & 11.54 & 12.86 & 7.36 & 73.23 & 14.09 \\
\hline & T.P.3 & 0.75 & 8.92 & 12.87 & 8.48 & 75.03 & 14.89 \\
\hline & T.P.4 & 0.86 & 11.60 & 11.82 & 5.70 & 70.74 & 14.45 \\
\hline & R.P.1 & 0.80 & 8.93 & 16.68 & 6.80 & 74.57 & 15.80 \\
\hline & R.P.2 & 0.71 & 7.68 & 16.24 & 6.90 & 72.18 & 13.40 \\
\hline & R.P.3 & 0.87 & 9.98 & 9.27 & 7.04 & 72.76 & 16.36 \\
\hline \multirow{2}{*}{ Taiyuan Formation } & T.P.4 & 0.81 & 11.94 & 12.14 & 8.72 & 53.36 & 17.96 \\
\hline & T.P.5 & 0.97 & 16.24 & 16.68 & 8.76 & 53.10 & 13.17 \\
\hline Lower Shanxi & T.P. 6 & 0.79 & 20.90 & 21.49 & 7.12 & 73.18 & 44.10 \\
\hline Formation & R.P. 4 & 0.68 & 26.53 & 26.34 & 7.34 & 72.54 & 53.06 \\
\hline \multirow{3}{*}{$\begin{array}{l}\text { Upper Shanxi } \\
\text { Formation }\end{array}$} & R.P.5 & 0.83 & 11.24 & 10.21 & 8.46 & 80.35 & 25.04 \\
\hline & R.P.6 & 0.88 & 16.30 & 16.91 & 7.20 & 84.20 & 37.73 \\
\hline & T.P.7 & 0.97 & 22.05 & 20.28 & 6.78 & 79.57 & 32.20 \\
\hline \multirow{5}{*}{ Penzi Formation } & T.P.8 & 0.84 & 8.26 & 17.38 & 8.24 & 77.08 & 17.32 \\
\hline & T.P.9 & 0.94 & 8.53 & 8.25 & 6.84 & 70.83 & 16.55 \\
\hline & T.P.10 & 0.89 & 8.67 & 9.50 & 10.44 & 78.00 & 16.72 \\
\hline & R.P.7 & 0.69 & 9.88 & 10.23 & 7.28 & 70.93 & 23.86 \\
\hline & R.P. 8 & 0.94 & 8.75 & 8.59 & 7.04 & 75.81 & 15.12 \\
\hline \multirow{2}{*}{ Taiyuan Formation } & T.P.11 & 0.87 & 15.76 & 16.18 & 9.02 & 53.17 & 19.88 \\
\hline & T.P.12 & 0.84 & 10.33 & 8.33 & 8.56 & 53.10 & 19.82 \\
\hline Lower Shanxi & T.P.13 & 0.64 & 5.78 & 5.79 & 9.68 & 74.97 & 21.57 \\
\hline Formation & R.P.9 & 0.67 & 5.42 & 6.46 & 7.30 & 72.19 & 27.41 \\
\hline $\begin{array}{l}\text { Upper Shanxi } \\
\text { Formation }\end{array}$ & R.P.10 & 0.58 & 6.16 & 5.14 & 6.34 & 84.91 & 37.71 \\
\hline
\end{tabular}



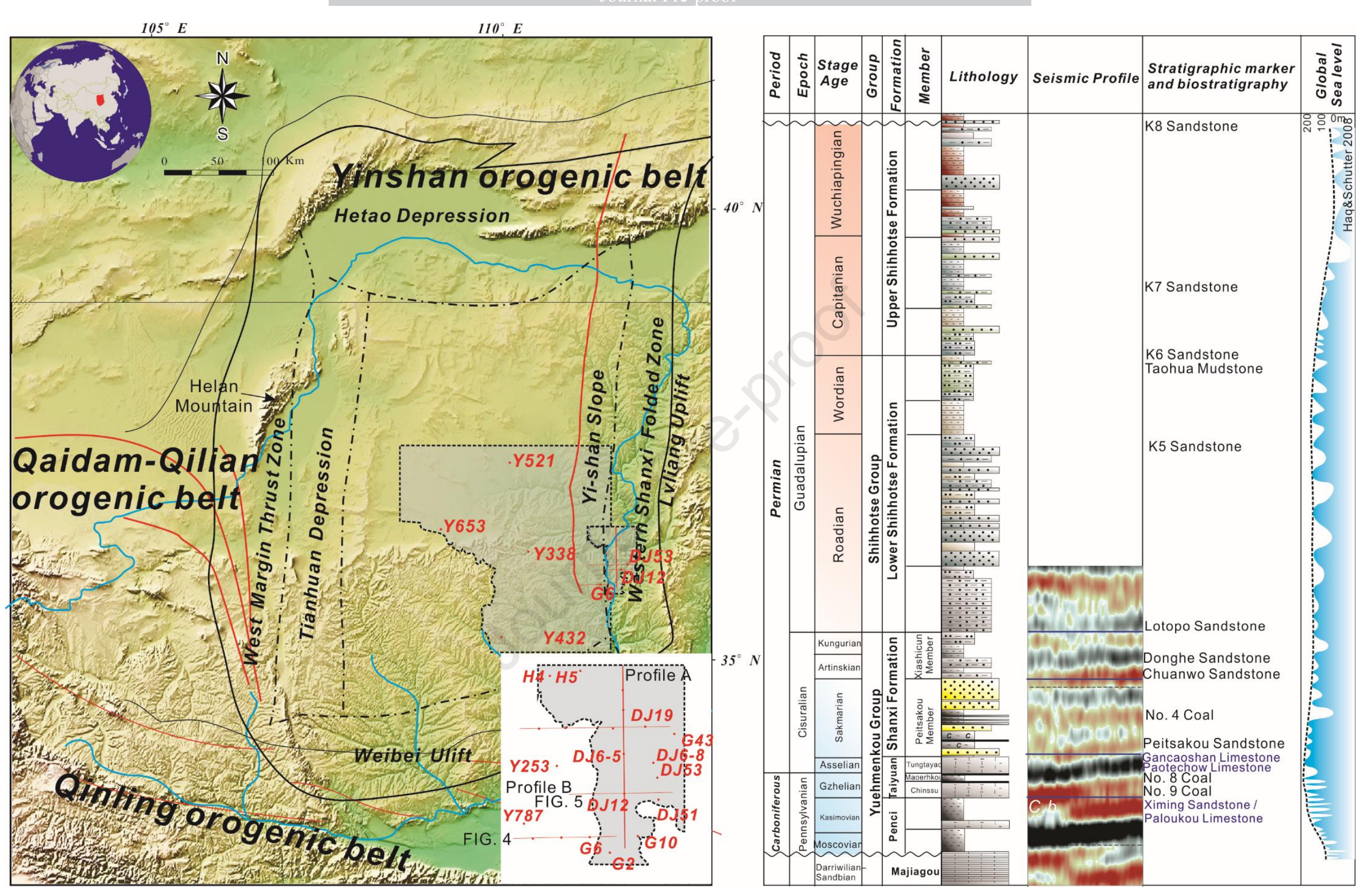

FIG 1 


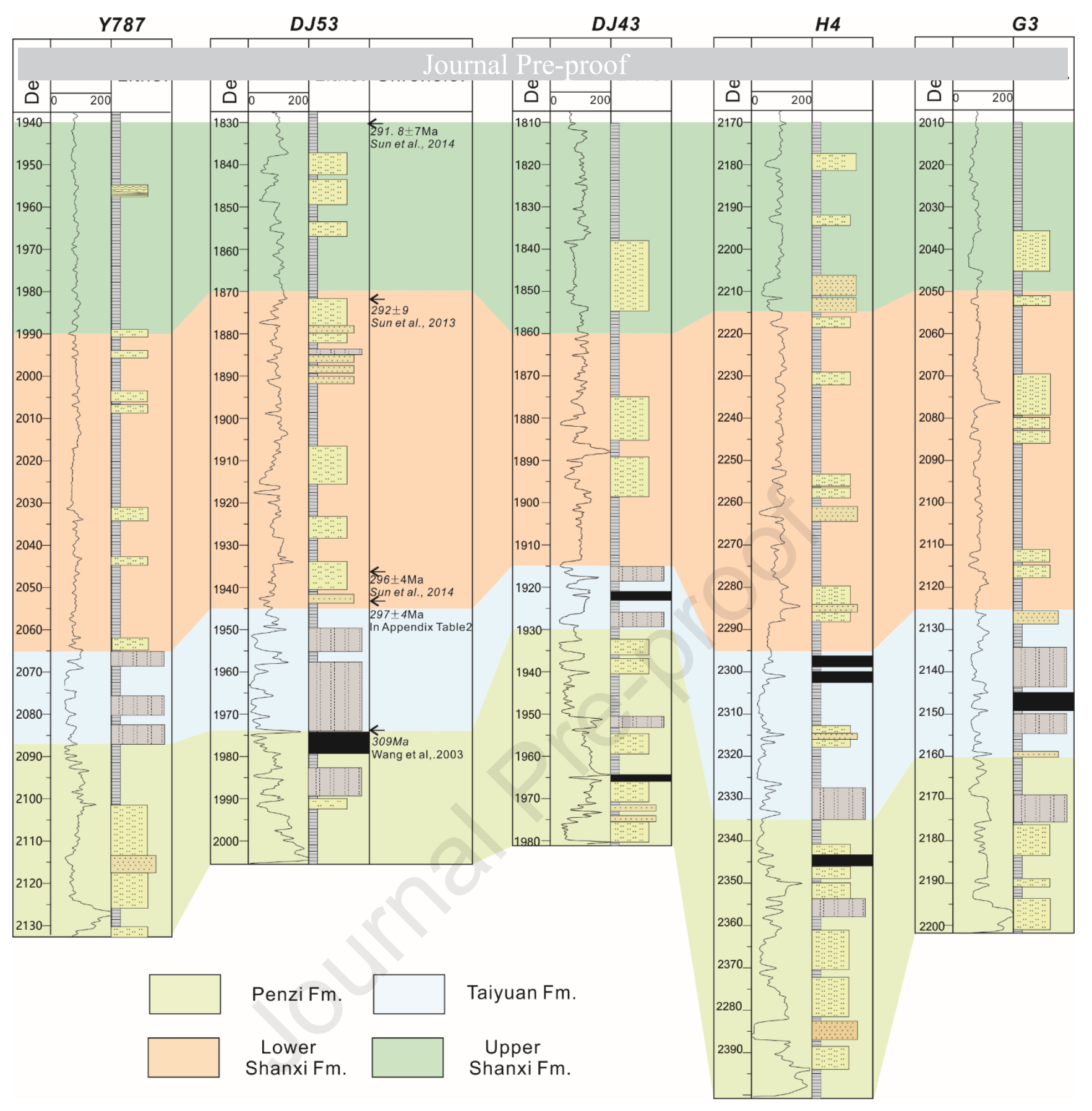

FIG 2 


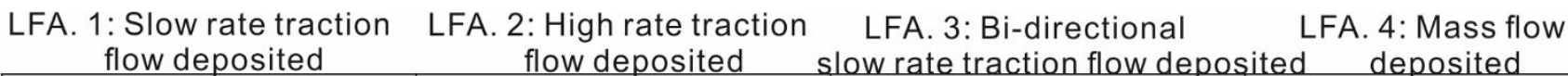

LFA. 5: Static water

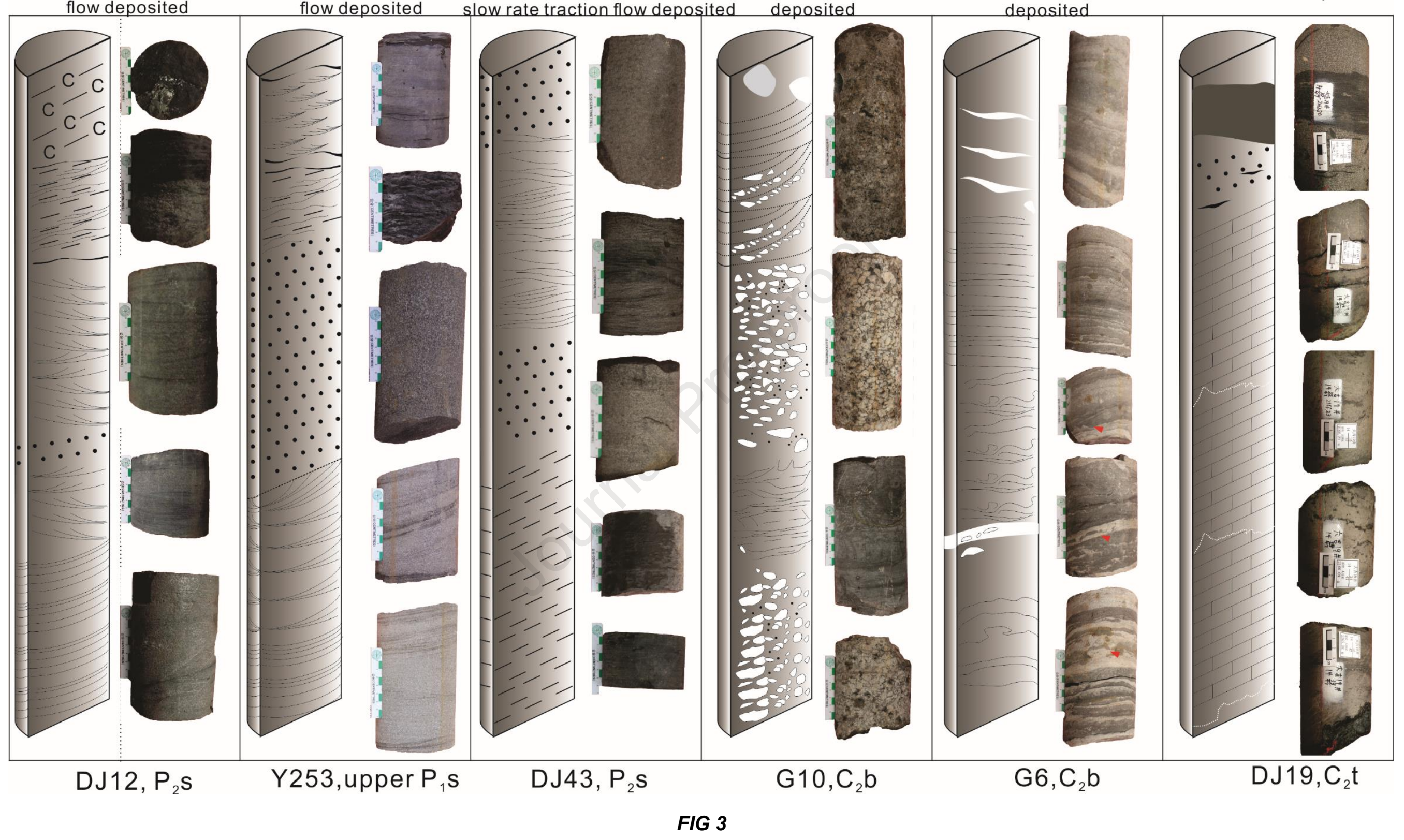


TWT/ms

G6

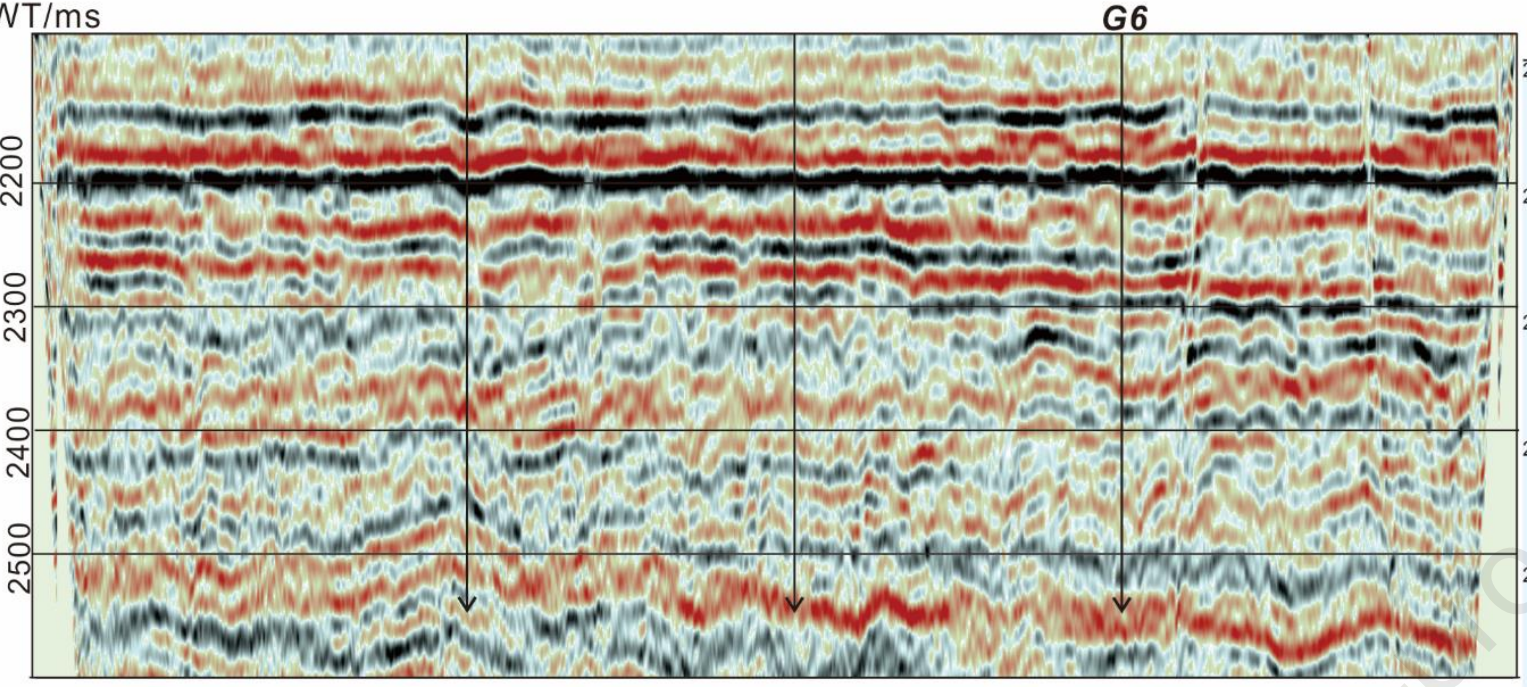

DEPTH/m
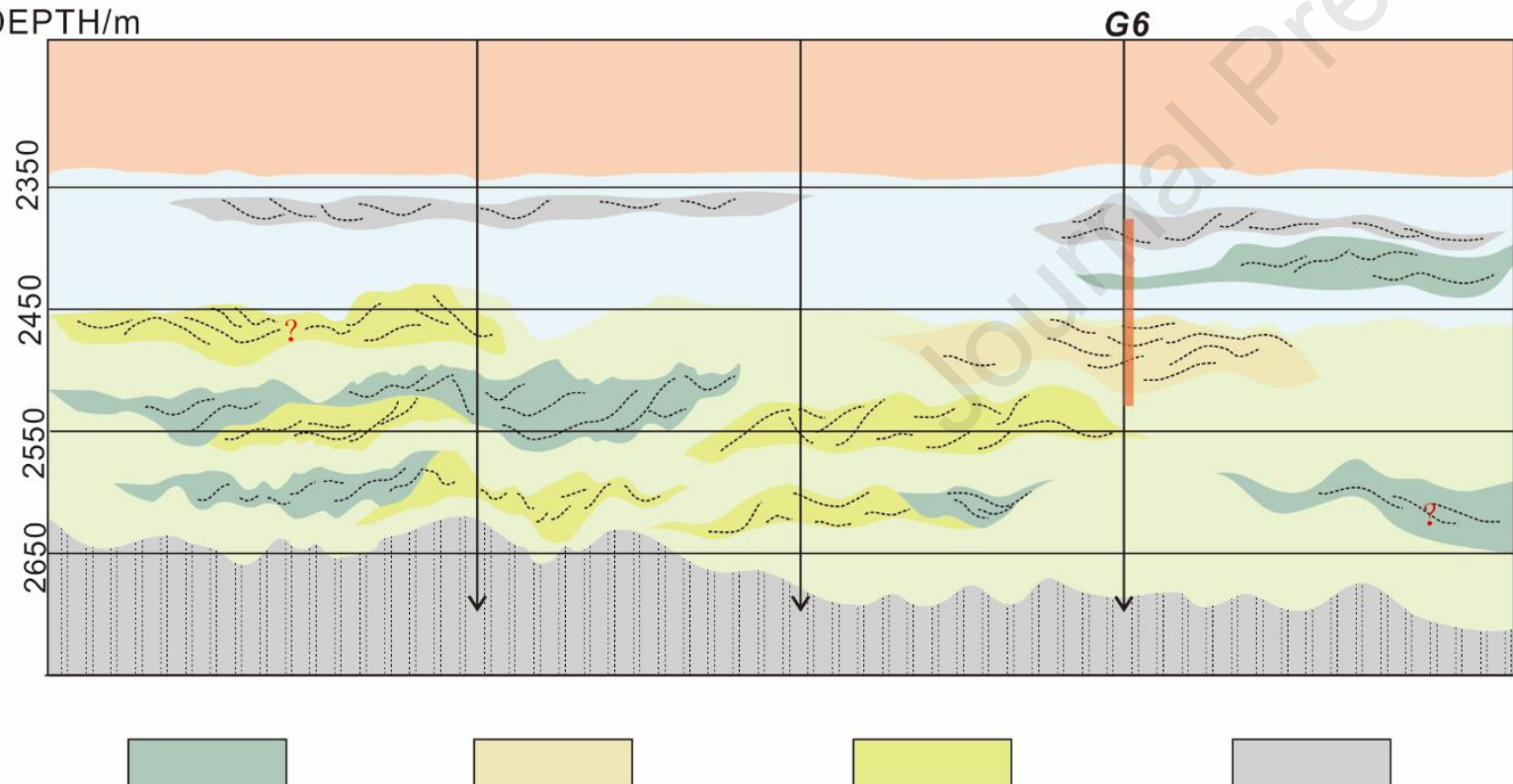

Tidal barrier deposited Tidal channel deposited Alluvial fan deposited

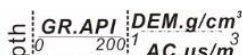
SP.MV 600 AC. $\mu \mathrm{ss} / \mathrm{m}$

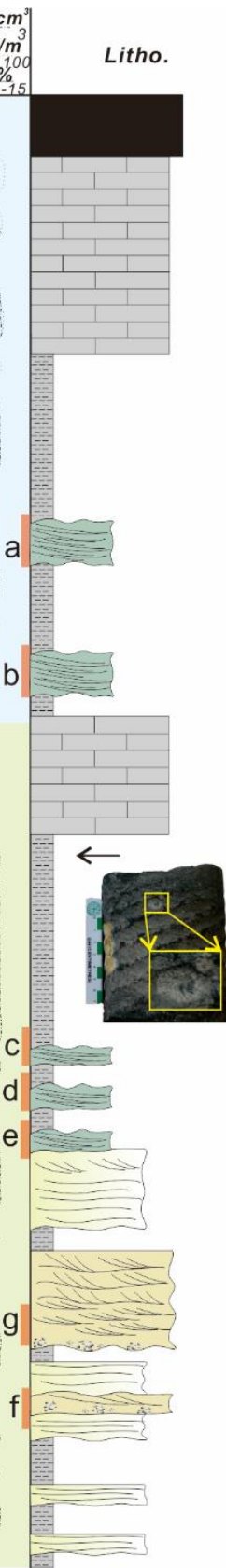

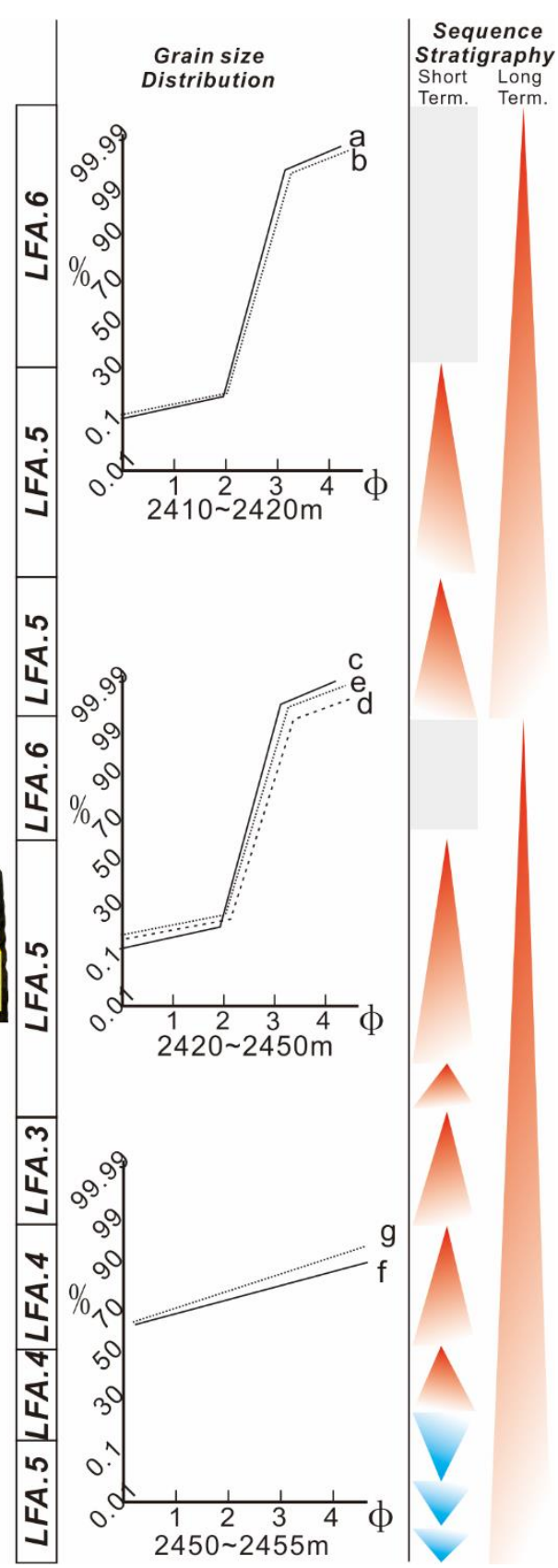

FIG 4 

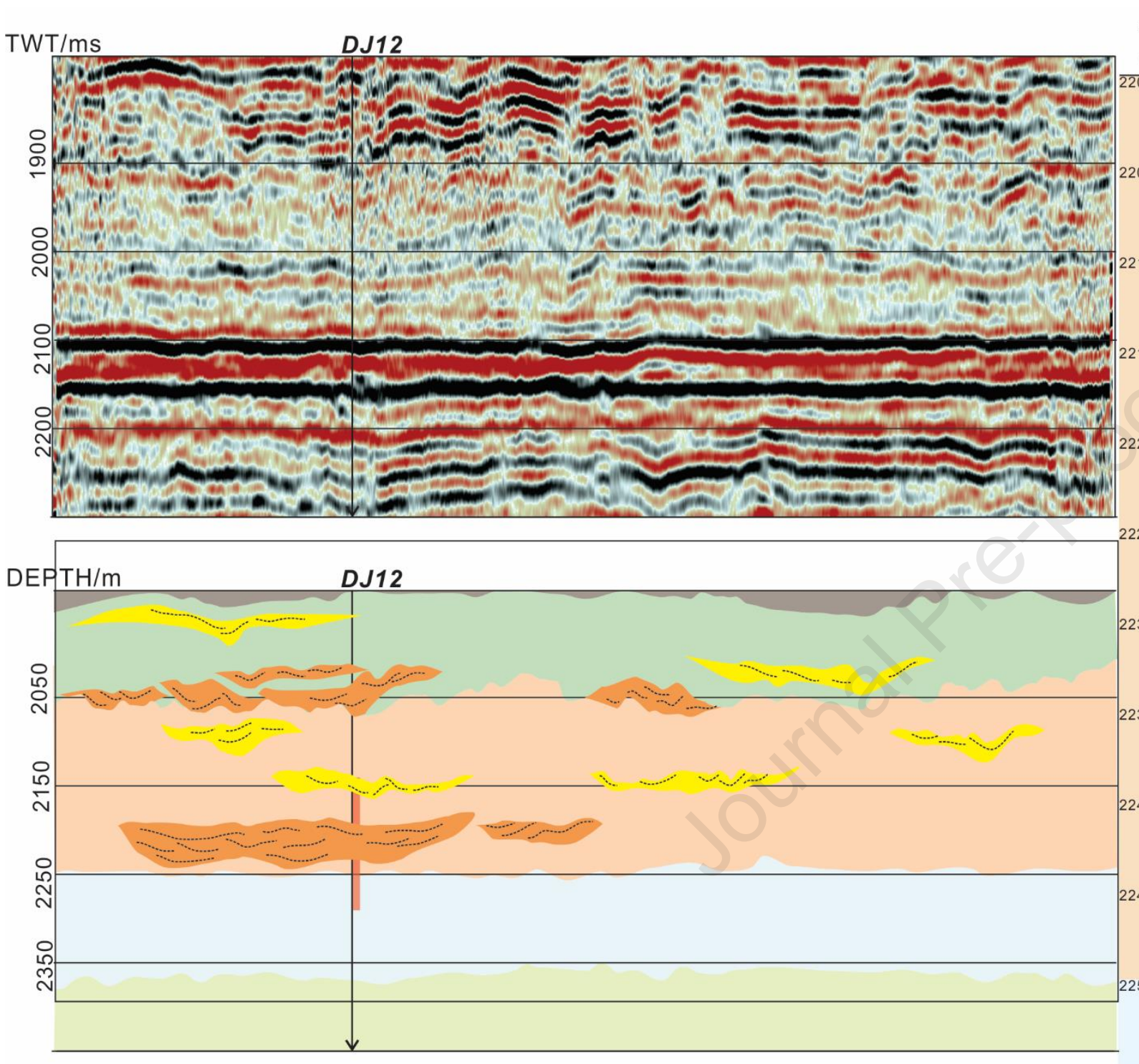

Meandering channel belt deposited

Braided channel belts deposited
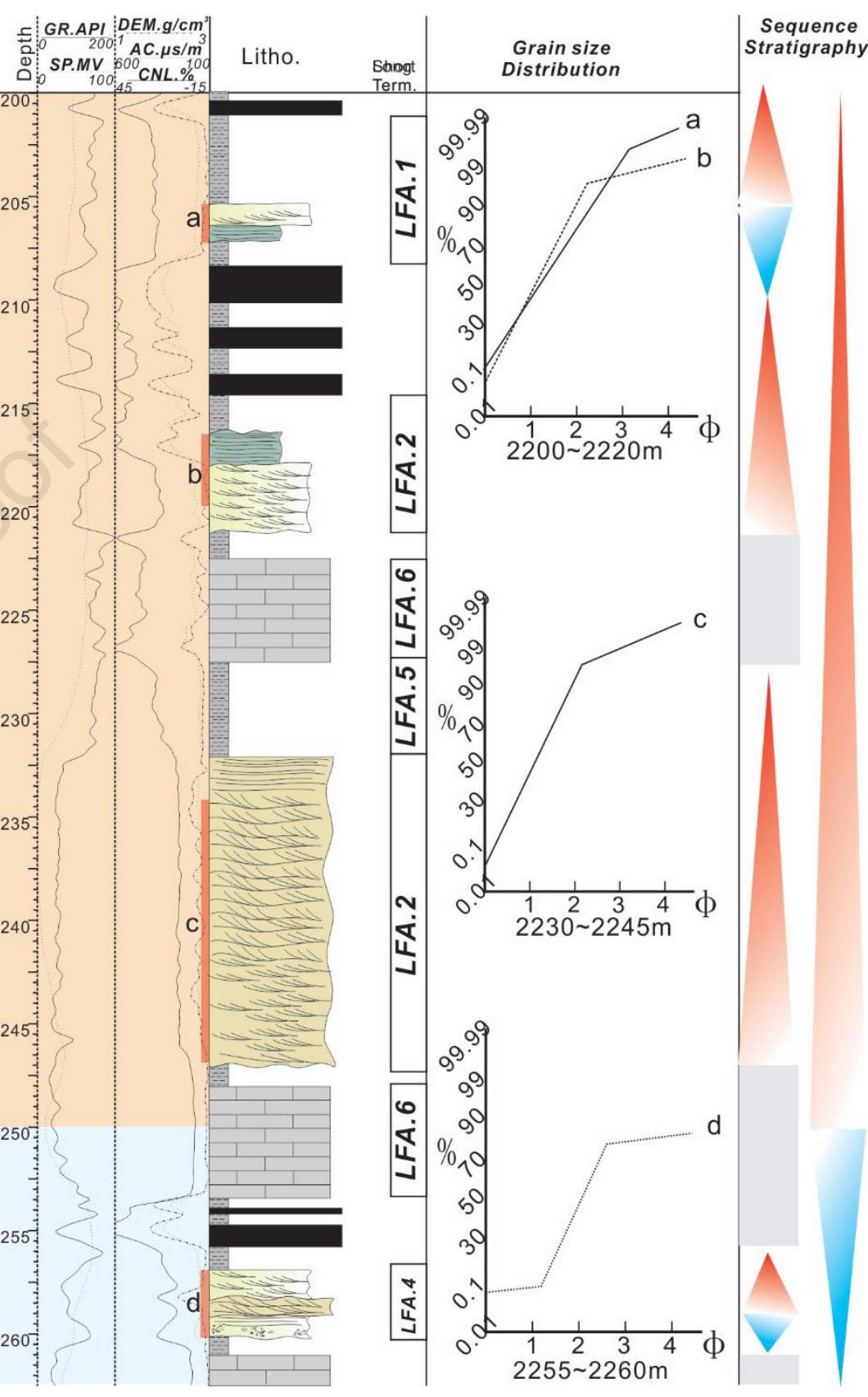

FIG 5 
DJ53-1942.23
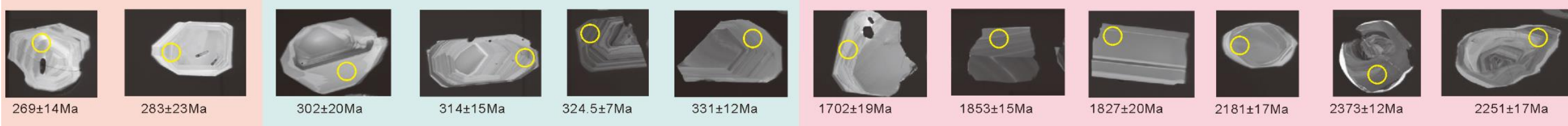

H5-1968.1

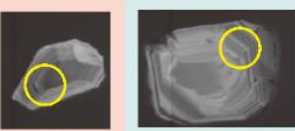

0
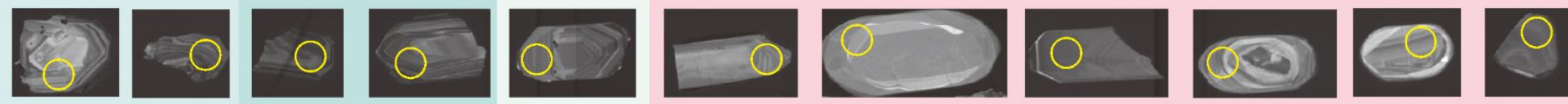

$296.5 \pm 7.7 \mathrm{Ma} \quad 312.9 \pm 9.5 \mathrm{Ma}$

$314 \pm 13 \mathrm{Ma}$

$325.6 \pm 9.2 \mathrm{Ma} \quad 354 \pm 4.8 \mathrm{Ma} \quad 431.8 \pm 6.3 \mathrm{Ma}$

$427.6 \pm 8.1 \mathrm{Ma}$

$440.5 \pm 8.4 \mathrm{Ma}$

$1828 \pm 20 \mathrm{Ma}$

$1845 \pm 12 \mathrm{Ma}$

$2138 \pm 11 \mathrm{Ma}$

$2387 \pm 18 M a \quad 2448 \pm 12 M a$

DJ51-2264.85
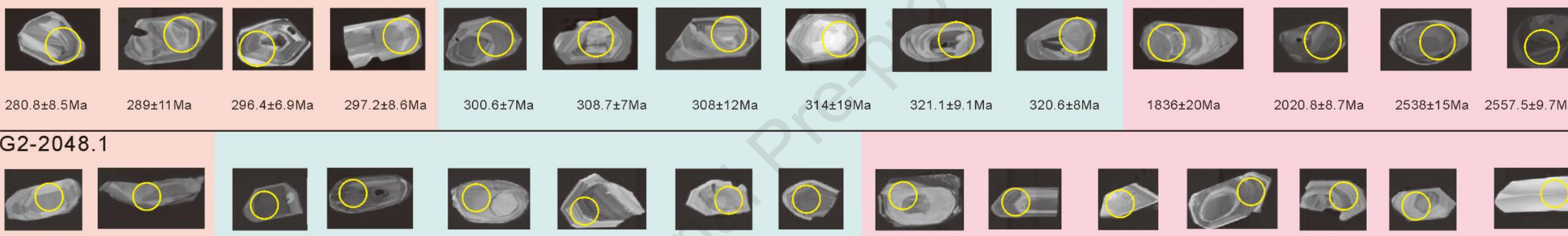

$296.4 \pm 6.9 \mathrm{Ma} \quad 297.2 \pm 8.6 \mathrm{M}$

$308.7 \pm 7 \mathrm{Ma}$

$308 \pm 12 \mathrm{Ma}$

$321.1 \pm 9.1 \mathrm{Ma}$

$320.6 \pm 8 \mathrm{Ma}$

$1836 \pm 20 \mathrm{Ma}$

$2020.8 \pm 8.7 \mathrm{Ma} \quad 2538 \pm 15 \mathrm{Ma} \quad 2557.5 \pm 9.7 \mathrm{Ma}$
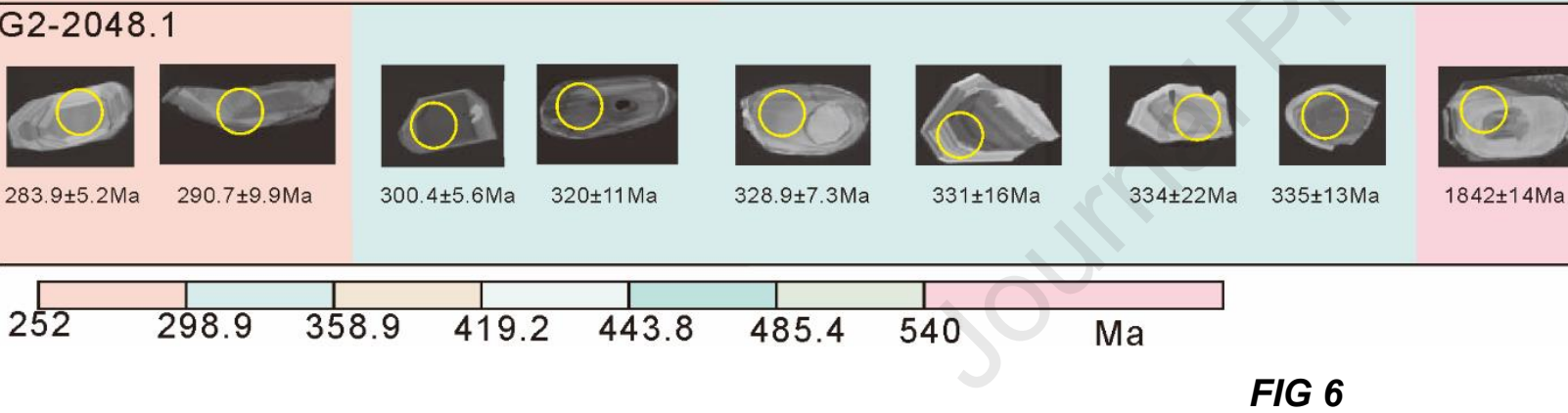


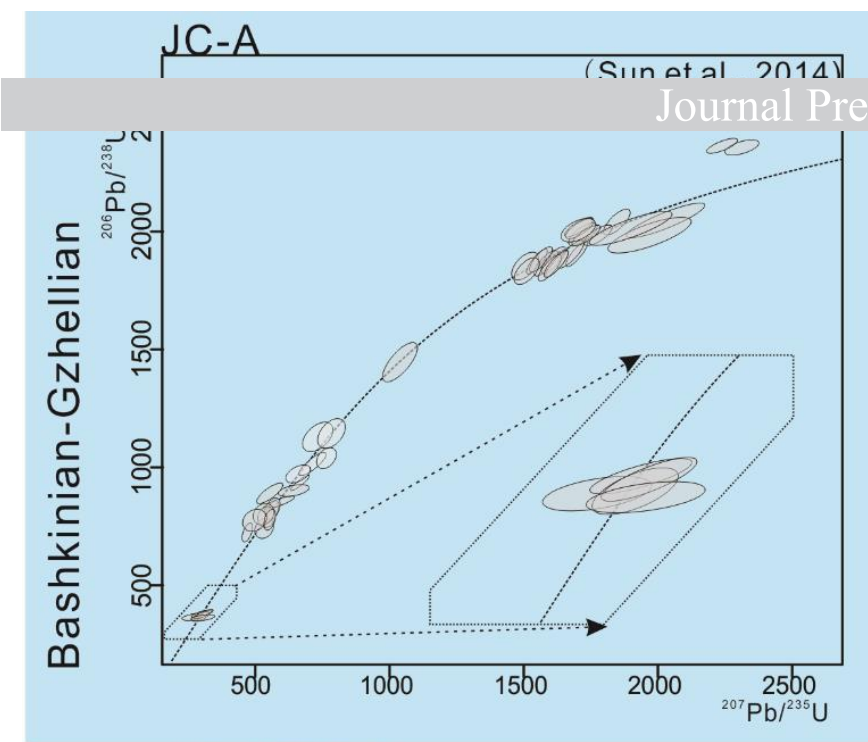

JC-B
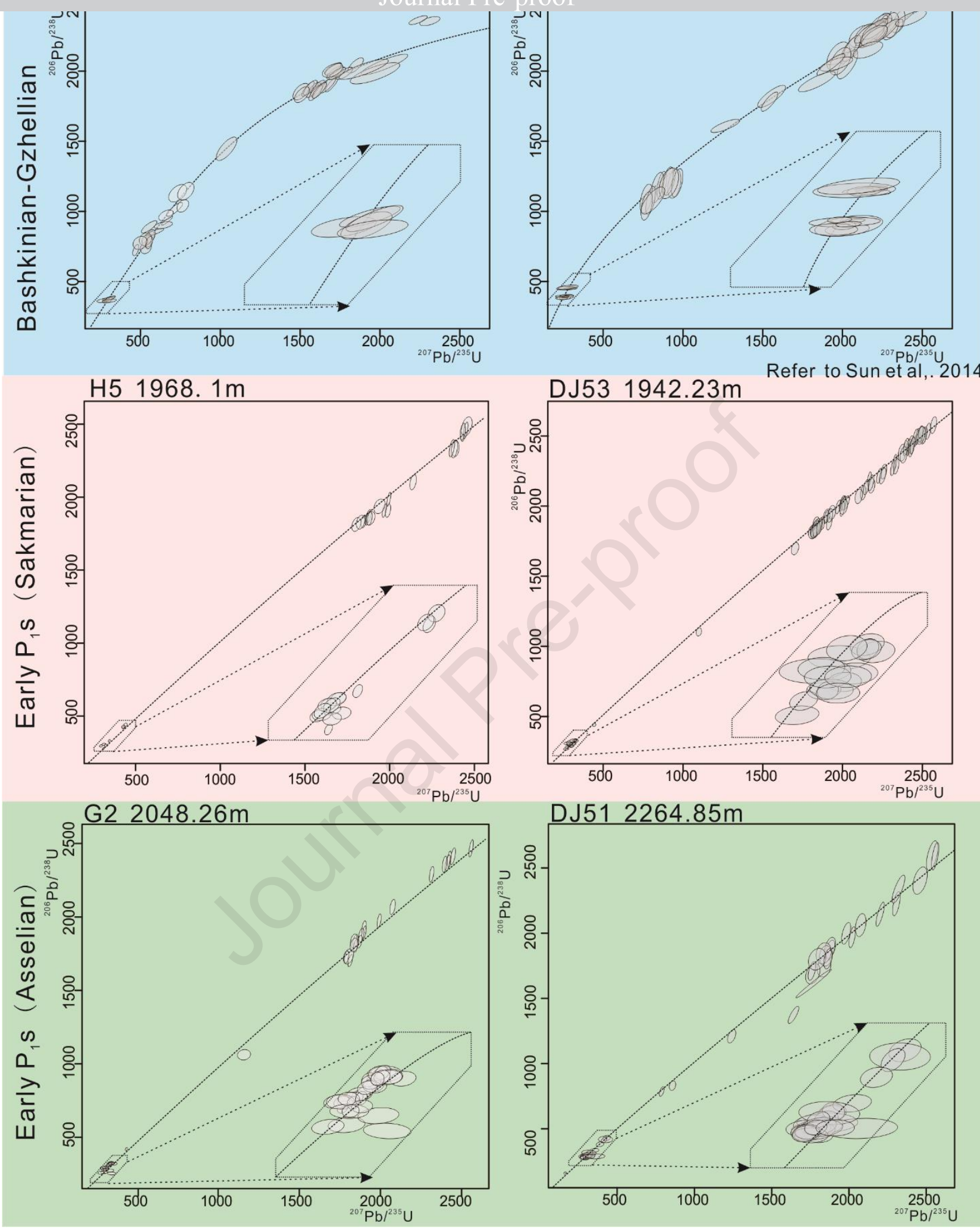

FIG 7 


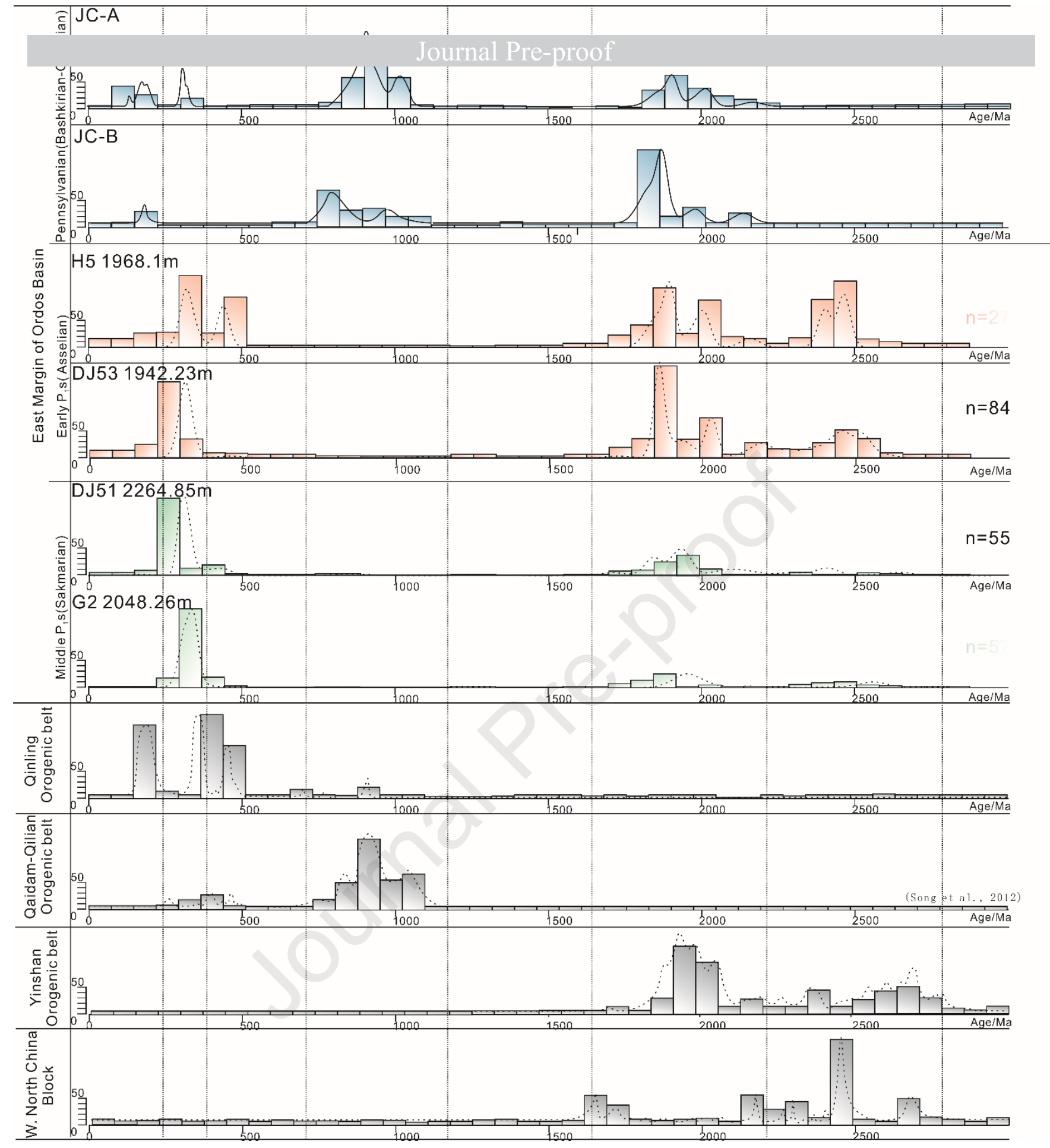

FIG 8 


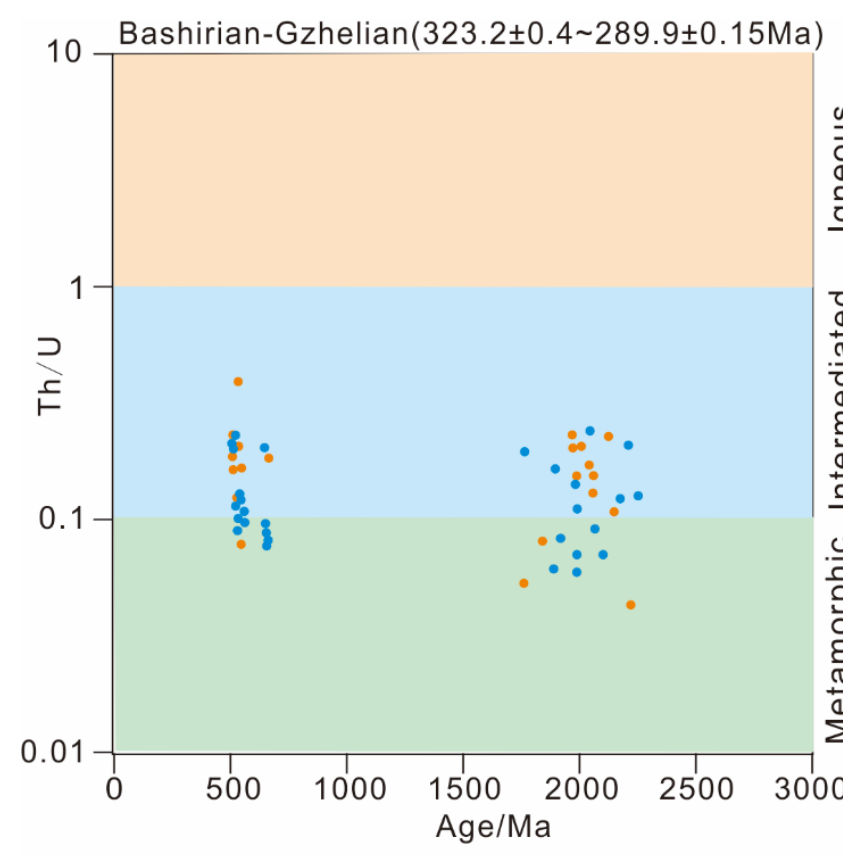

a $\quad \mathrm{JC}-\mathrm{A} \quad \cdot \mathrm{JC}-\mathrm{B}$

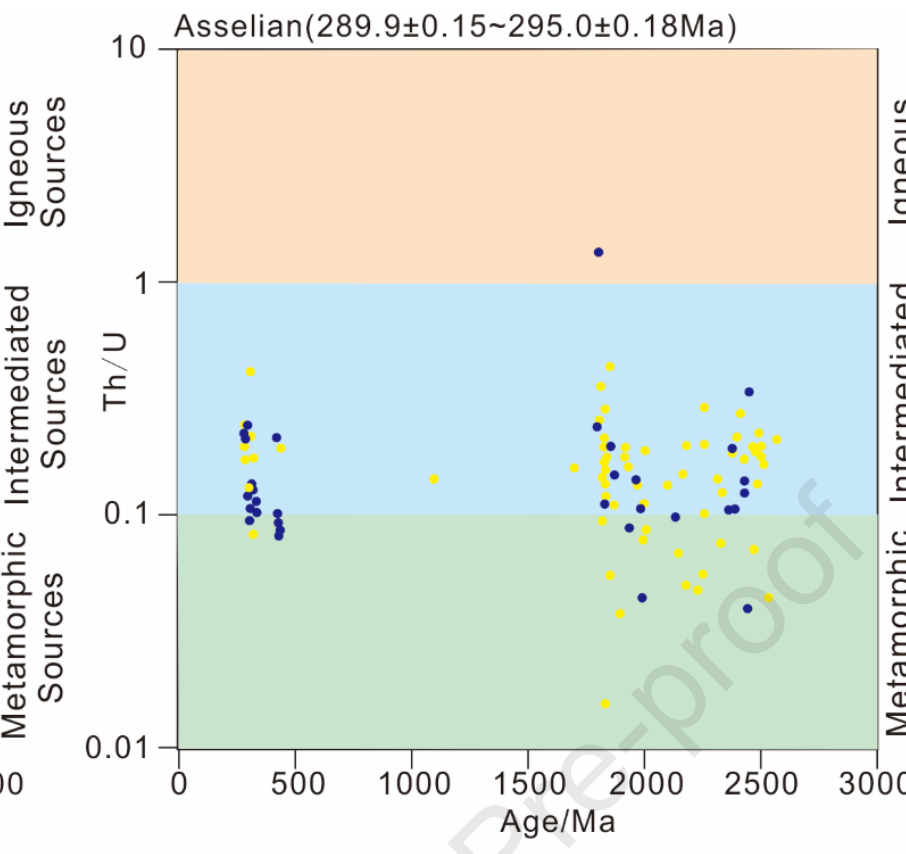

b)

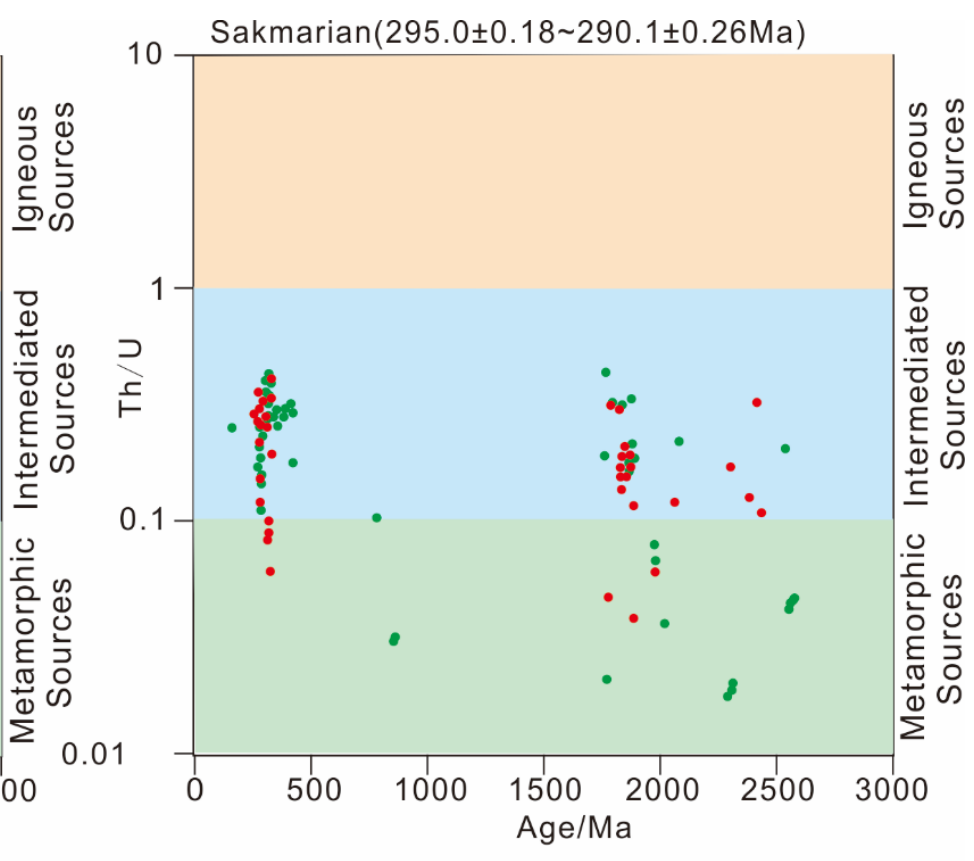

C - DJ51-2264.85 • G2-2048.26

FIG 9 


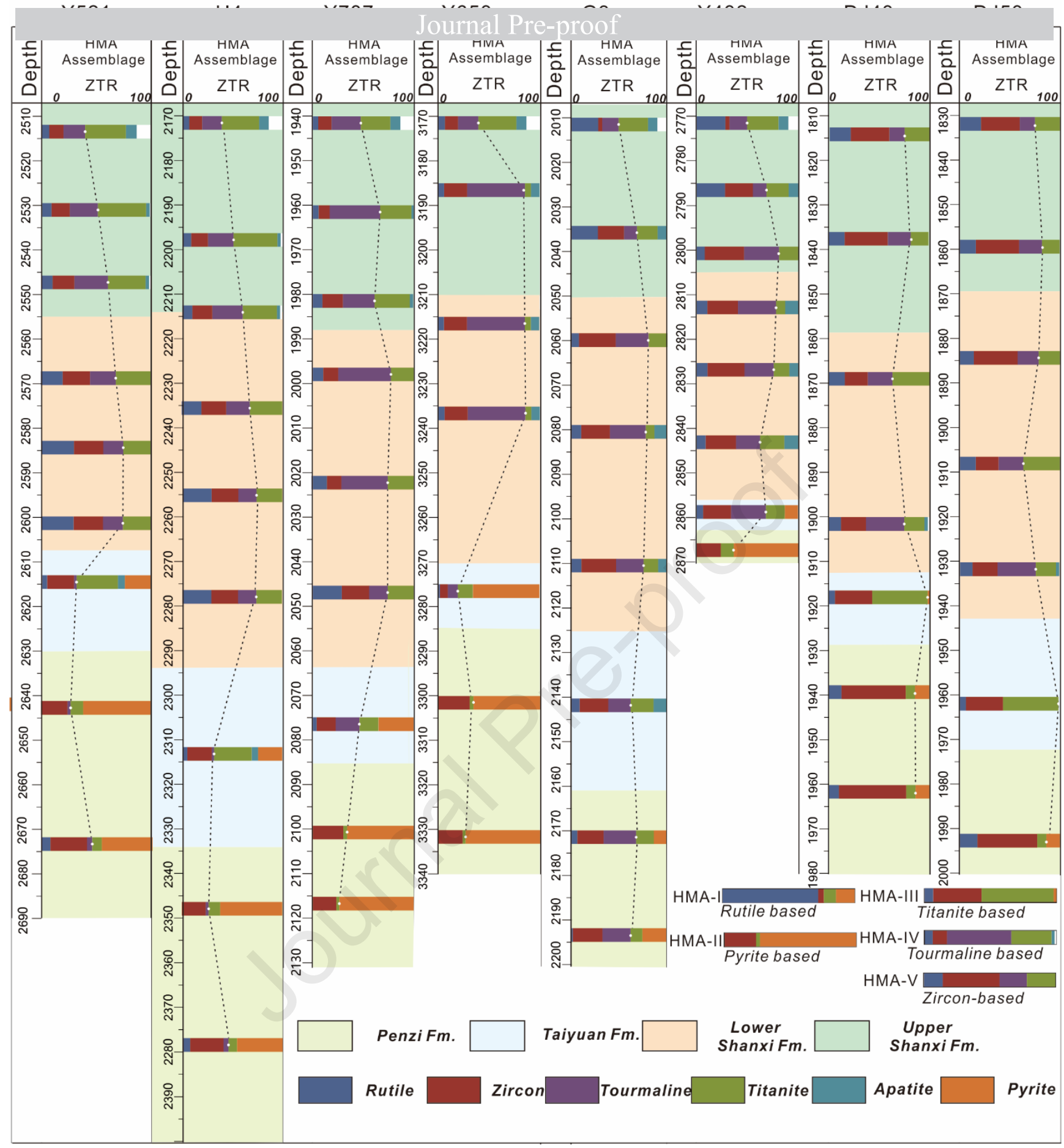

FIG 10 

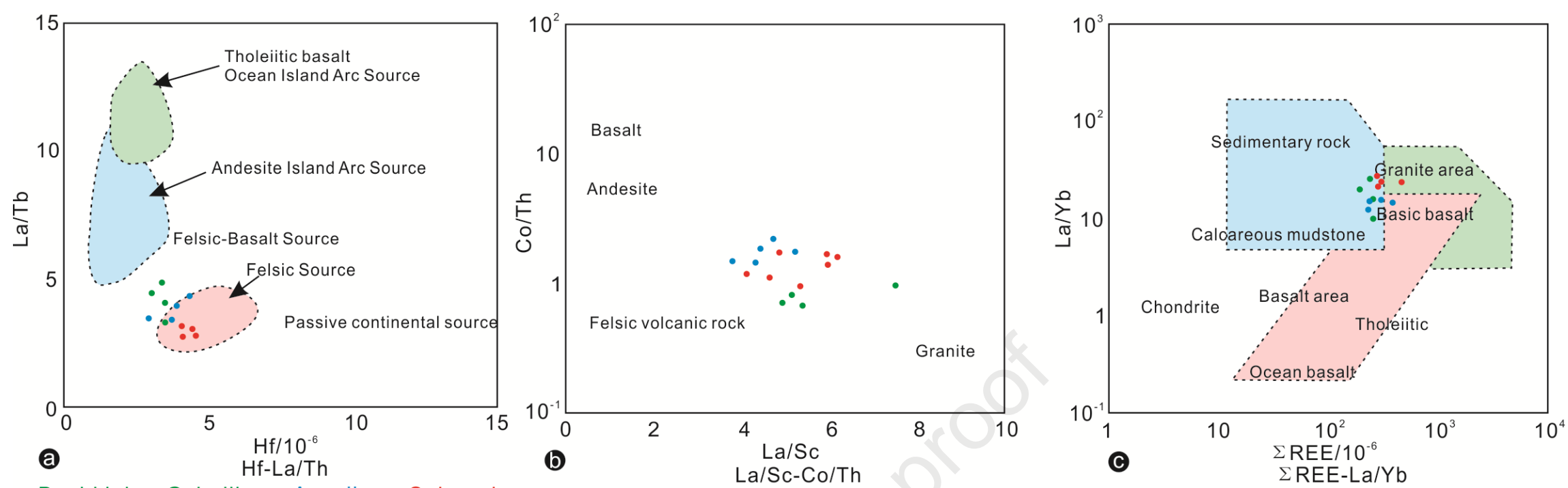

- Bashkinian-Gzhellian • Asselian • Sakmarian

$\odot$

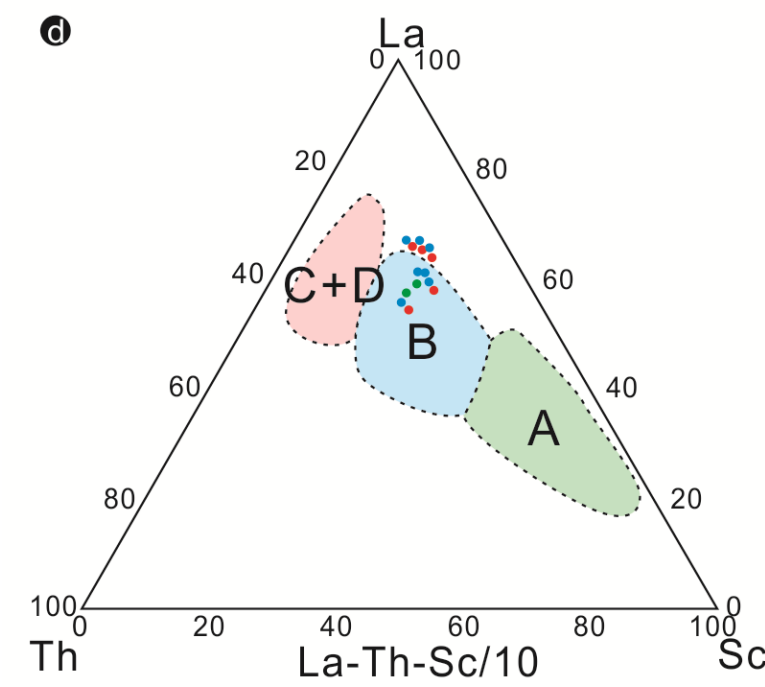

e

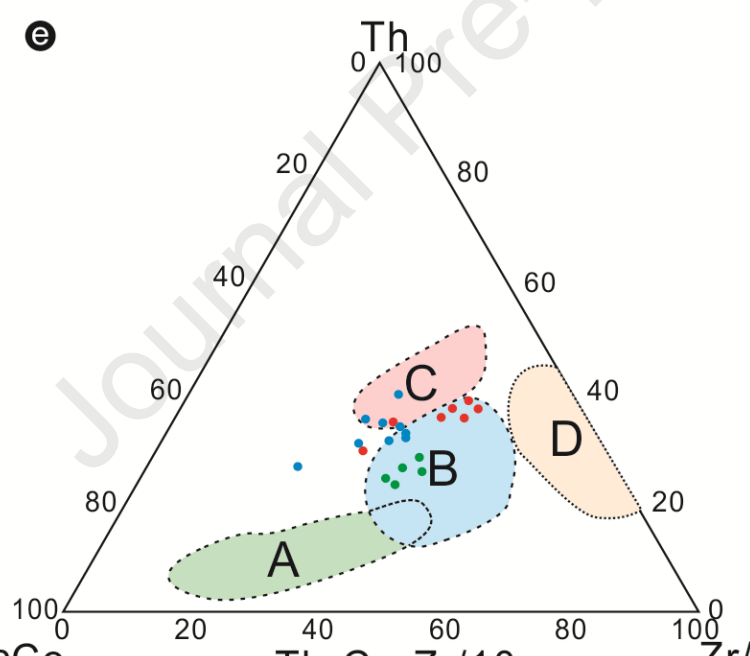

Th-Co-Zr/10

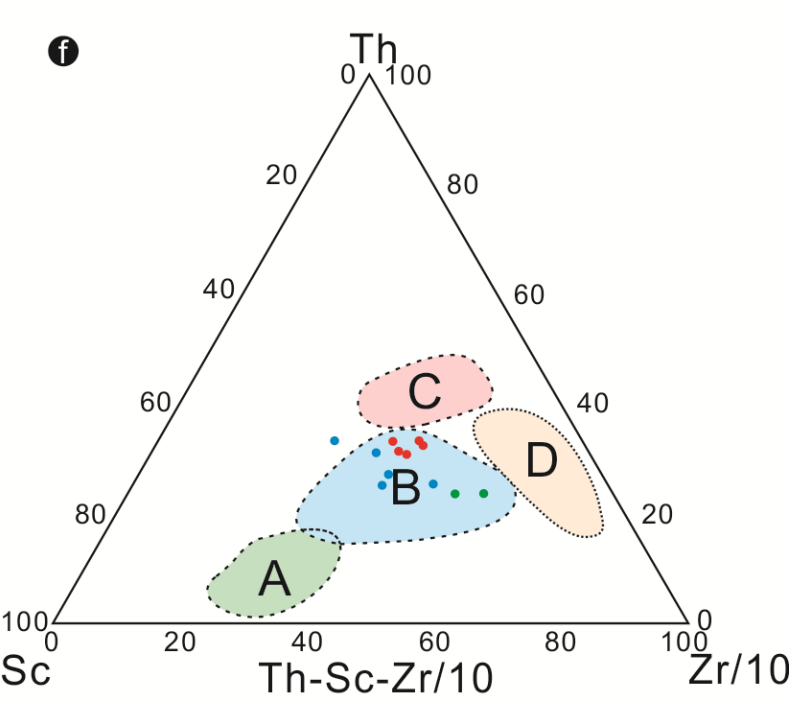

A-Continental island arc B-Ocean island arc C-Active continental margin D-Passive continental margin FIG 11 

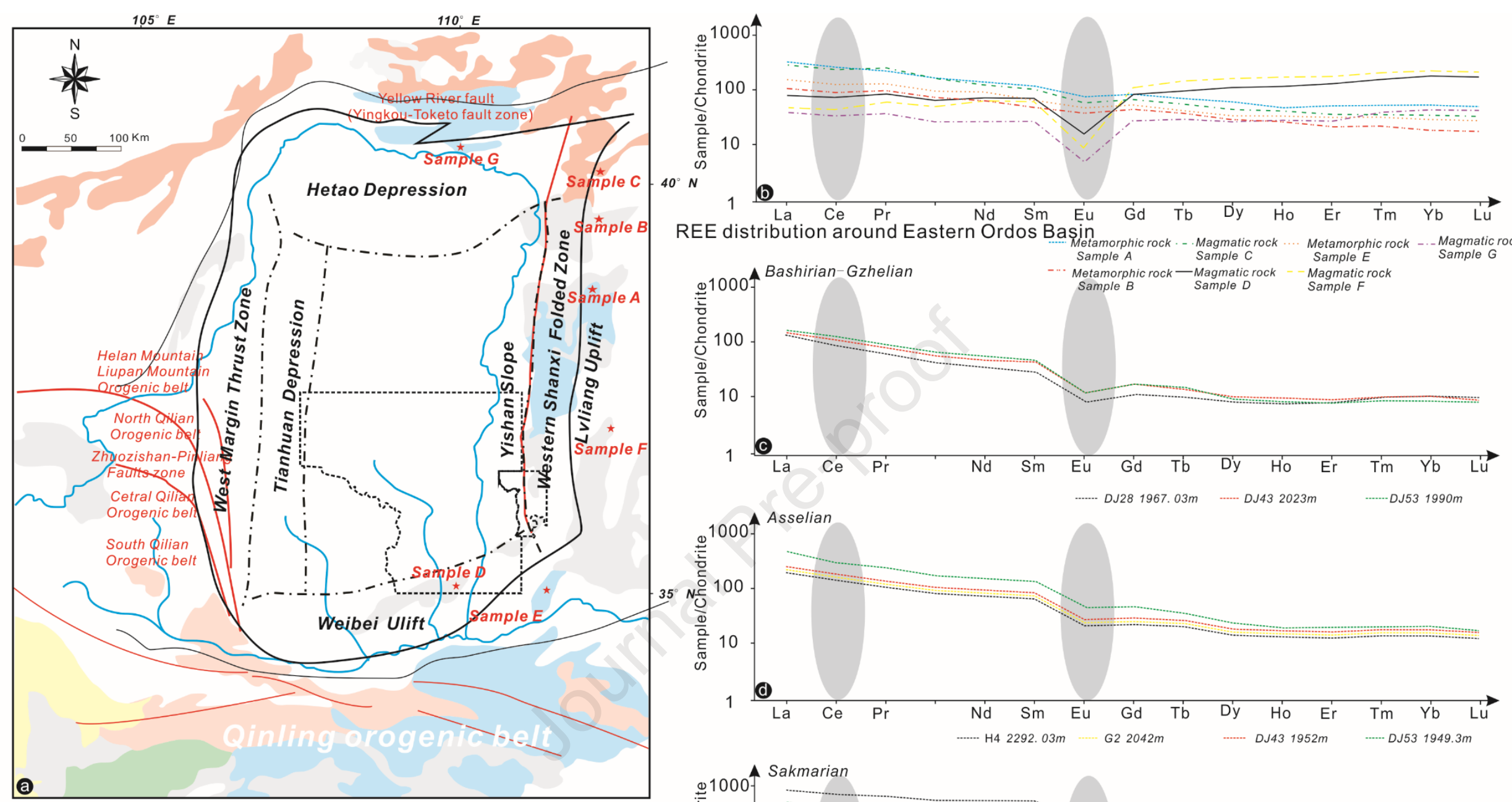

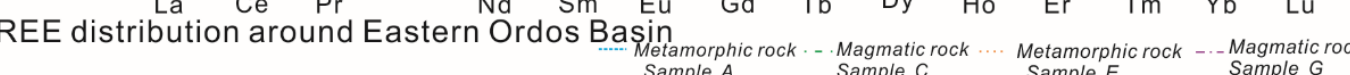
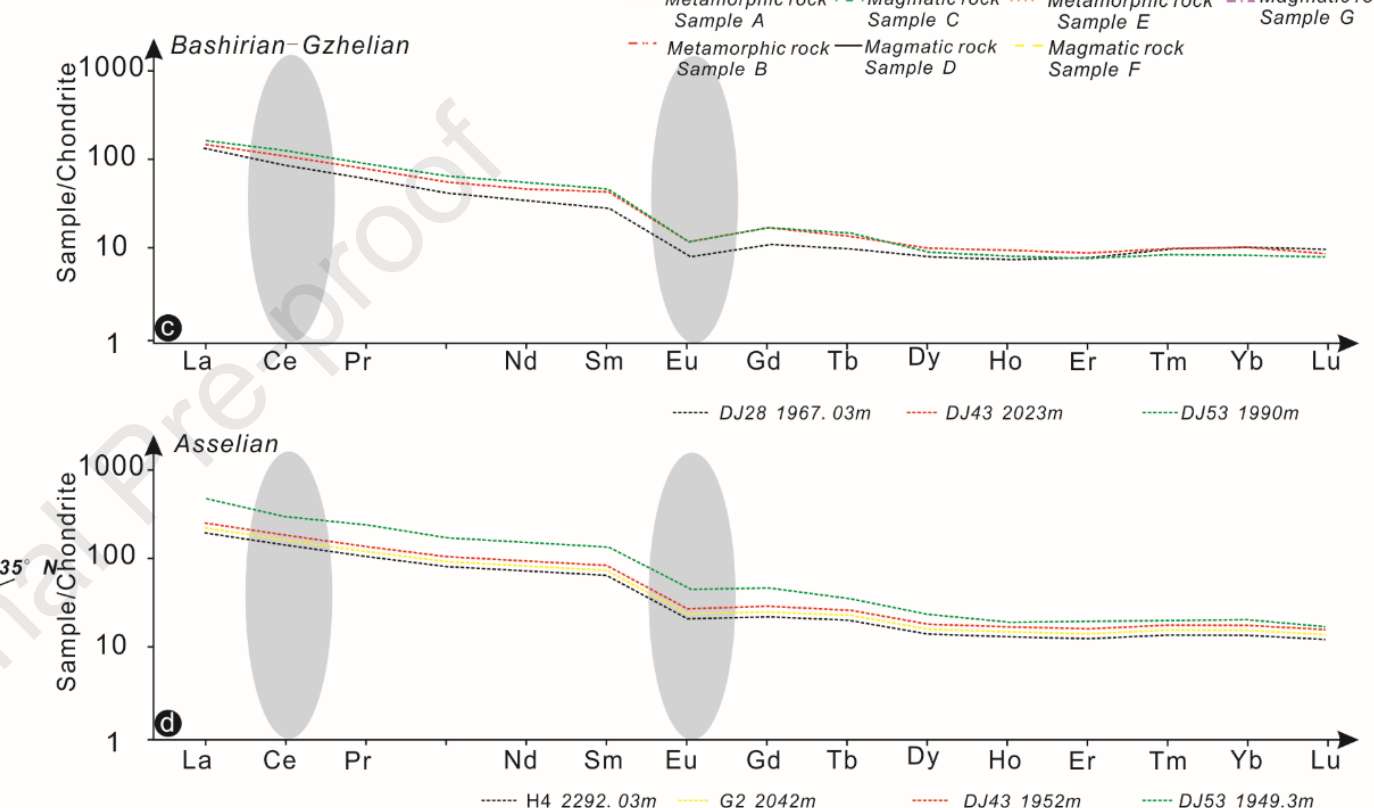

Early to middle Paleozoic Metamorphased sedimentary and igneous rocks

Middle-Lower Paleozoic dolomites and limestone with shales and sandstones

Upper Paleozoic sandstones and shales with thin bed carbonates

Mesozoic marine Sandstones, Shale and Carbonates

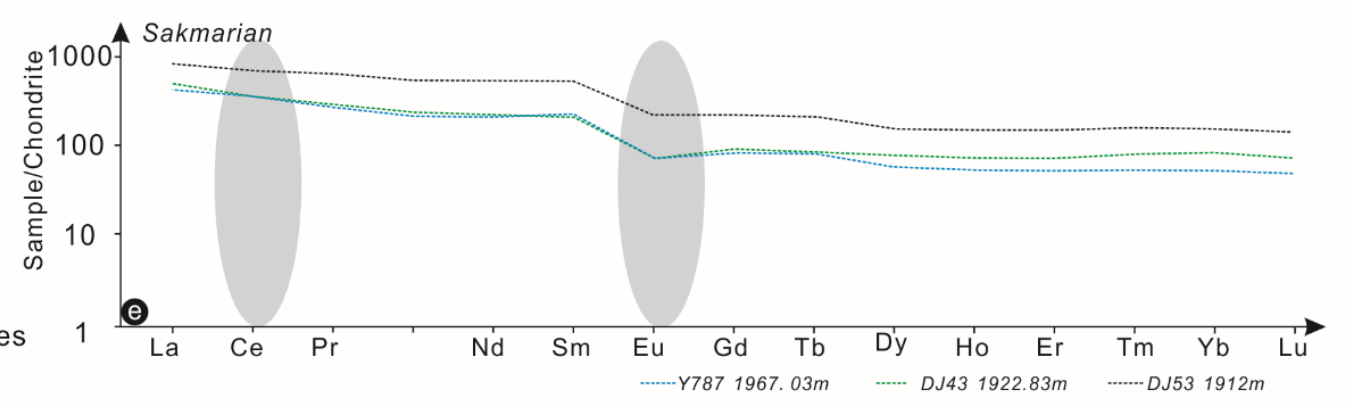

Mesozoic/Cenozoic non-marine sandstones and shales with minor conglomates

FIG 12 

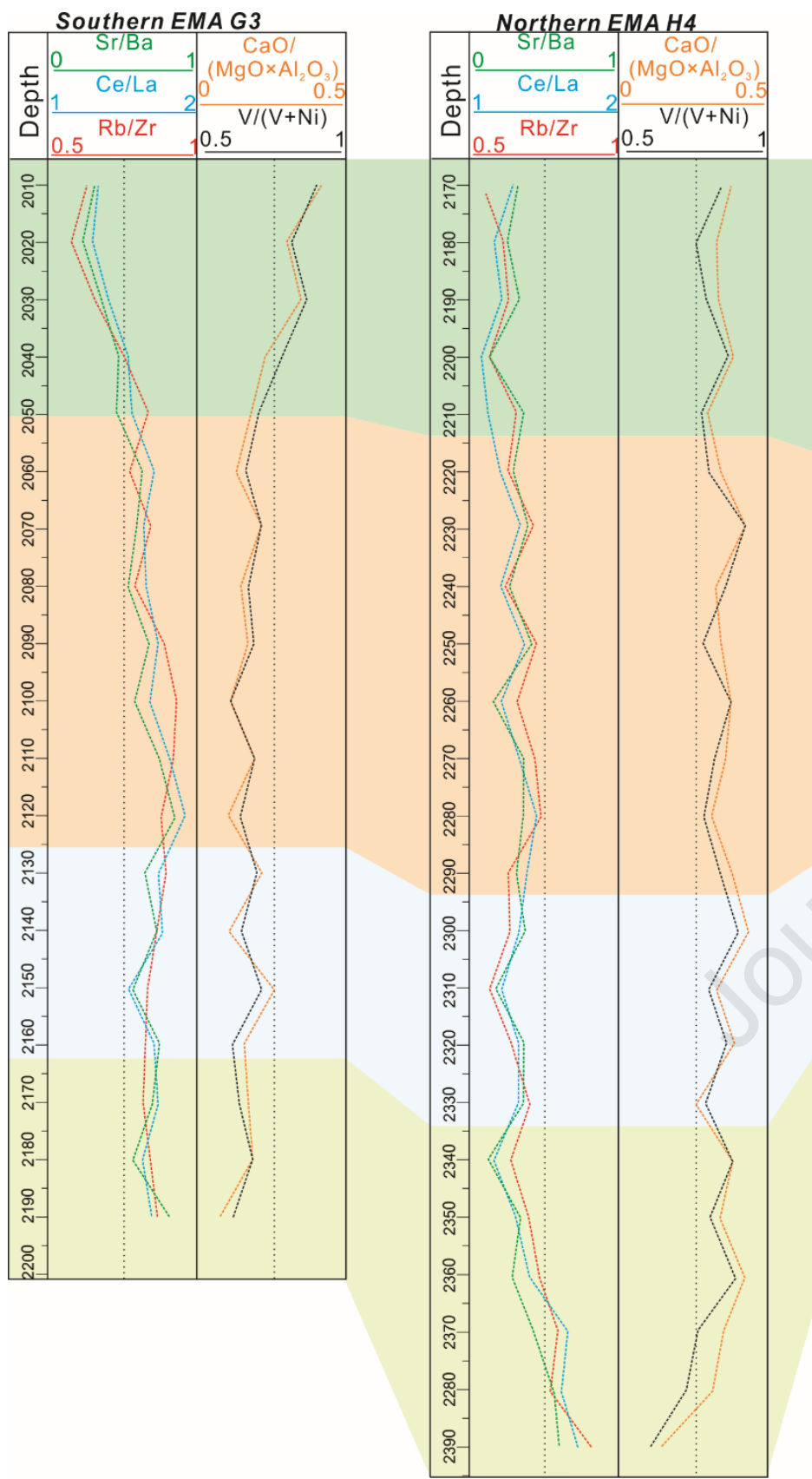
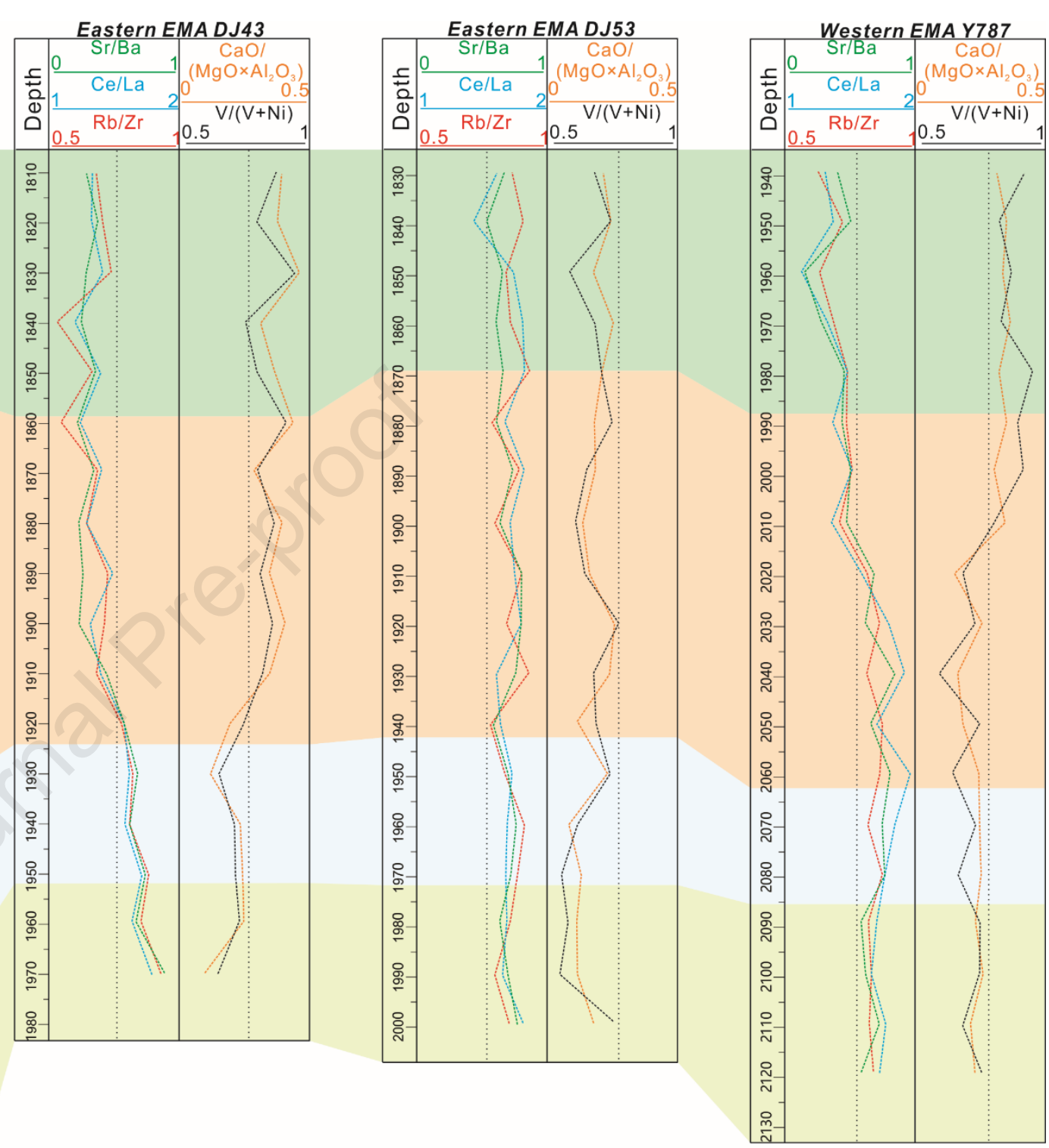

Penzi Fm.

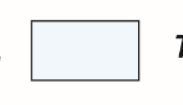

Taiyuan Fm.

Lower Shanxi Fm.

Upper Shanxi Fm. 


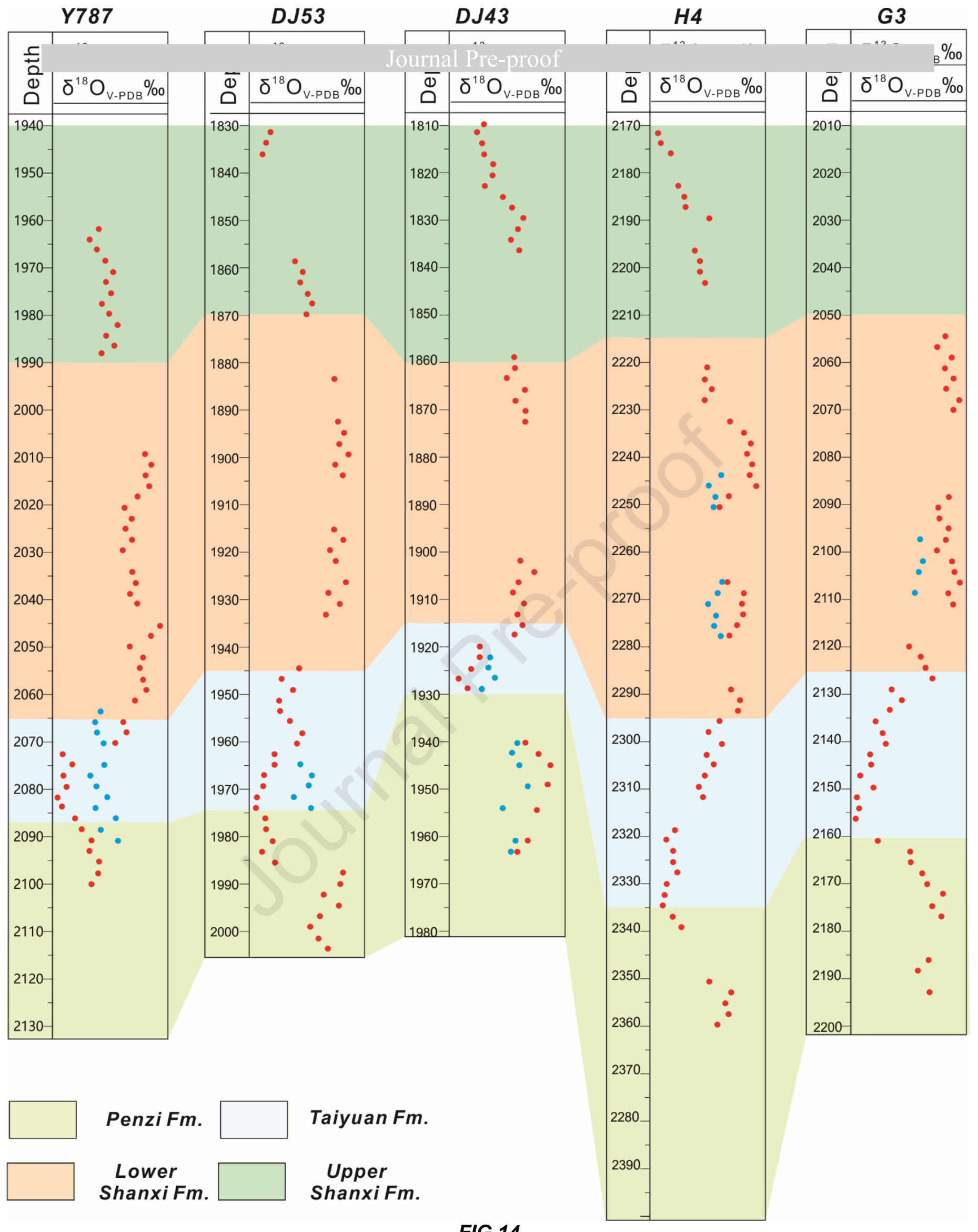

FIG 14 


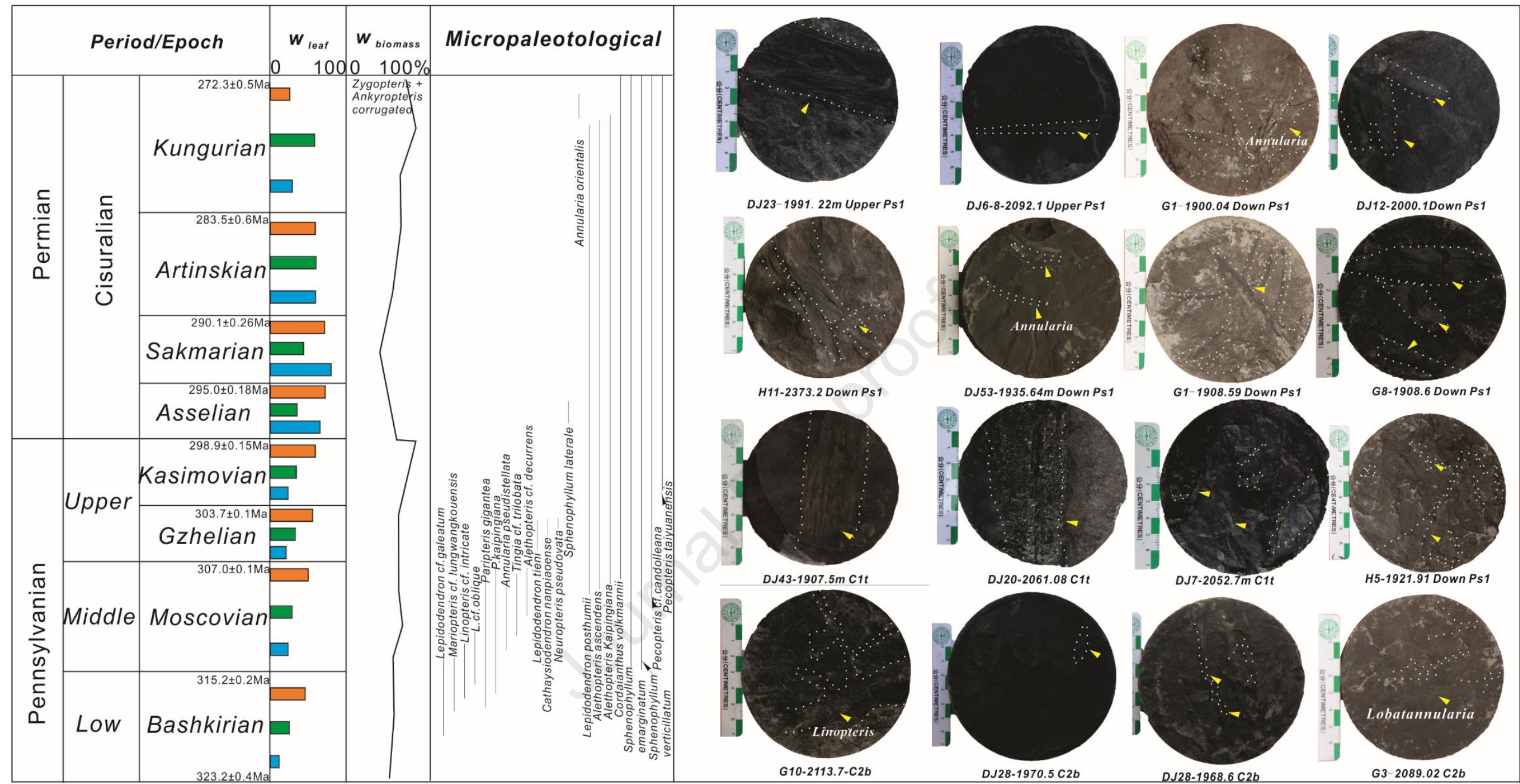

Root fossil

Stem fossil

Leaf fossil

FIG 15 

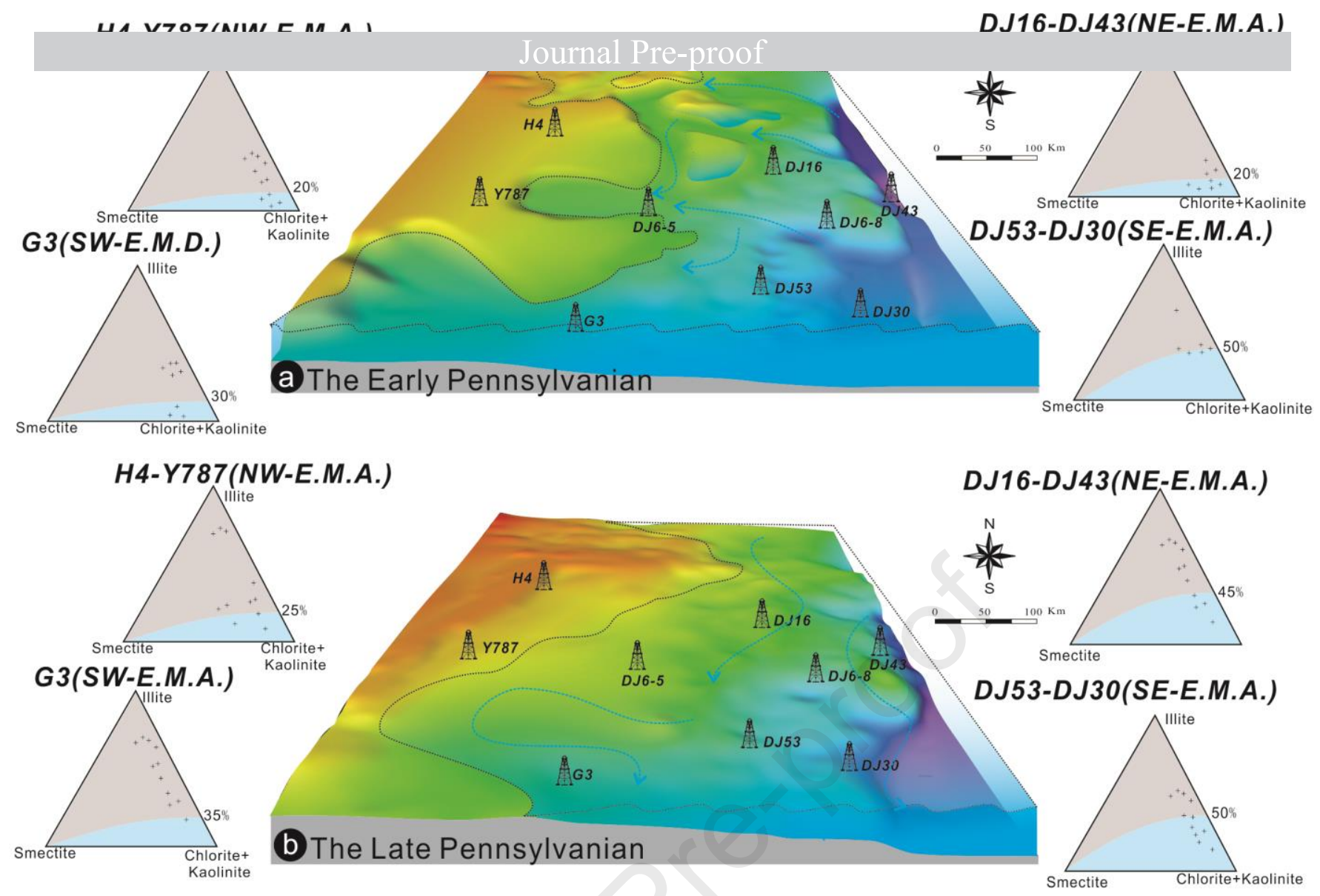

H4-Y787(NW-E.M.A.)
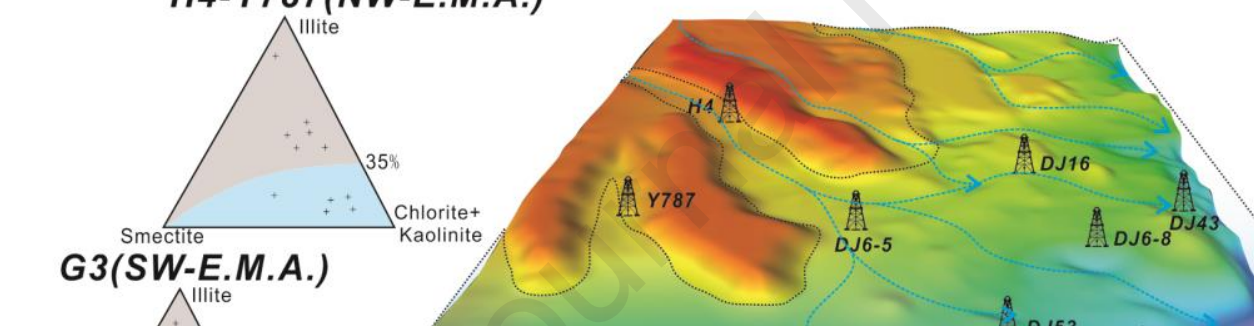

DJ16-DJ43(NE-E.M.A.)

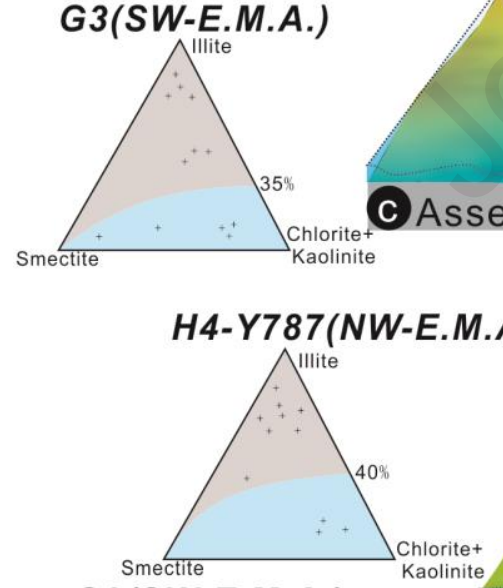

1 1787 DJ6-5

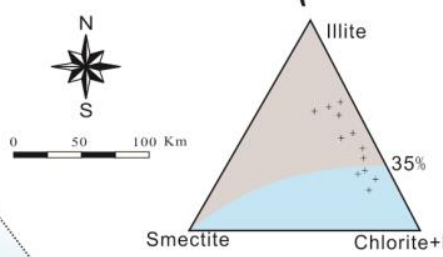

DJ53-DJ30(SE-E.M.A.)

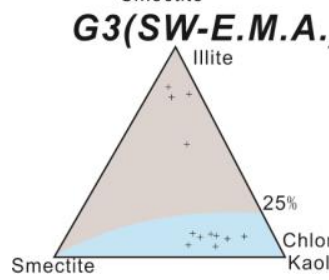

dSakmarian

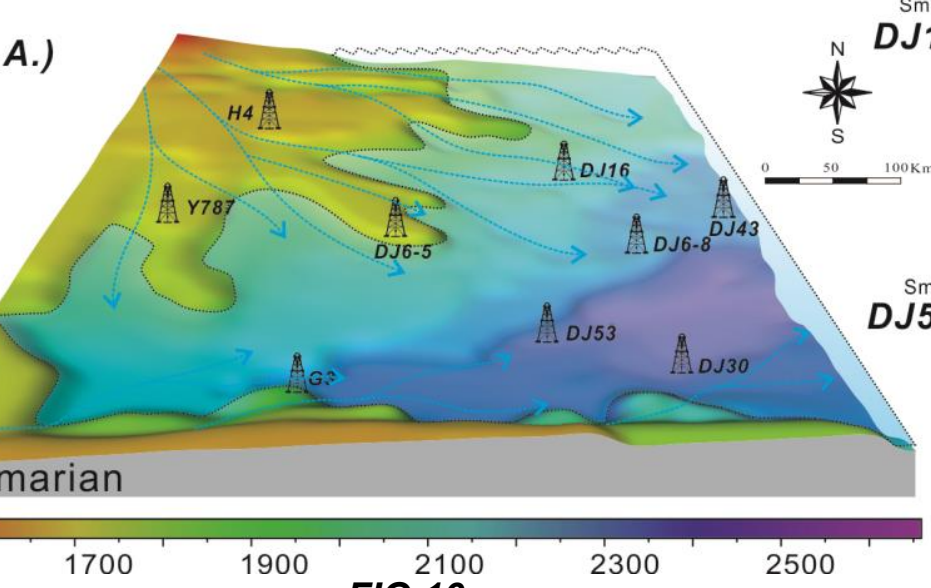

J16-DJ43(NE-E.M.A.)

FIG 16 
DJ6-5

DJ12

$\mathrm{NC} S$

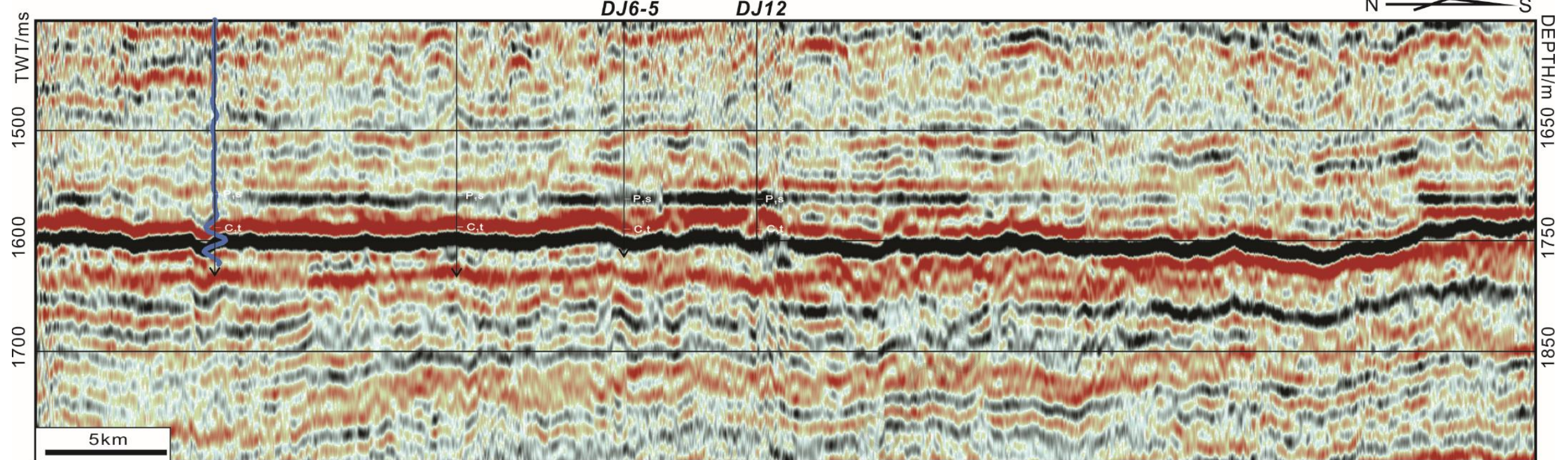

DJ6-5 DJ12

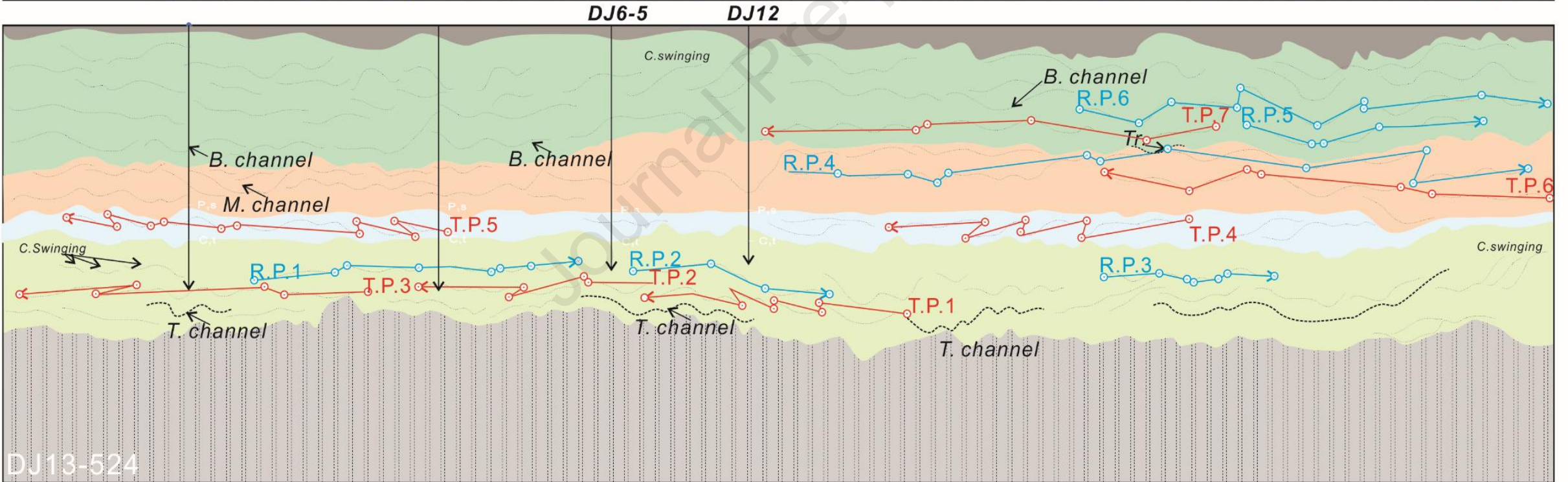

Transgression
Regression

direction(R.D.)
Penzi Fm. $\square$ Taiyuan Fm. Lower Shanxi Fm $\longleftarrow$ direction(T.D.)

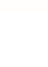



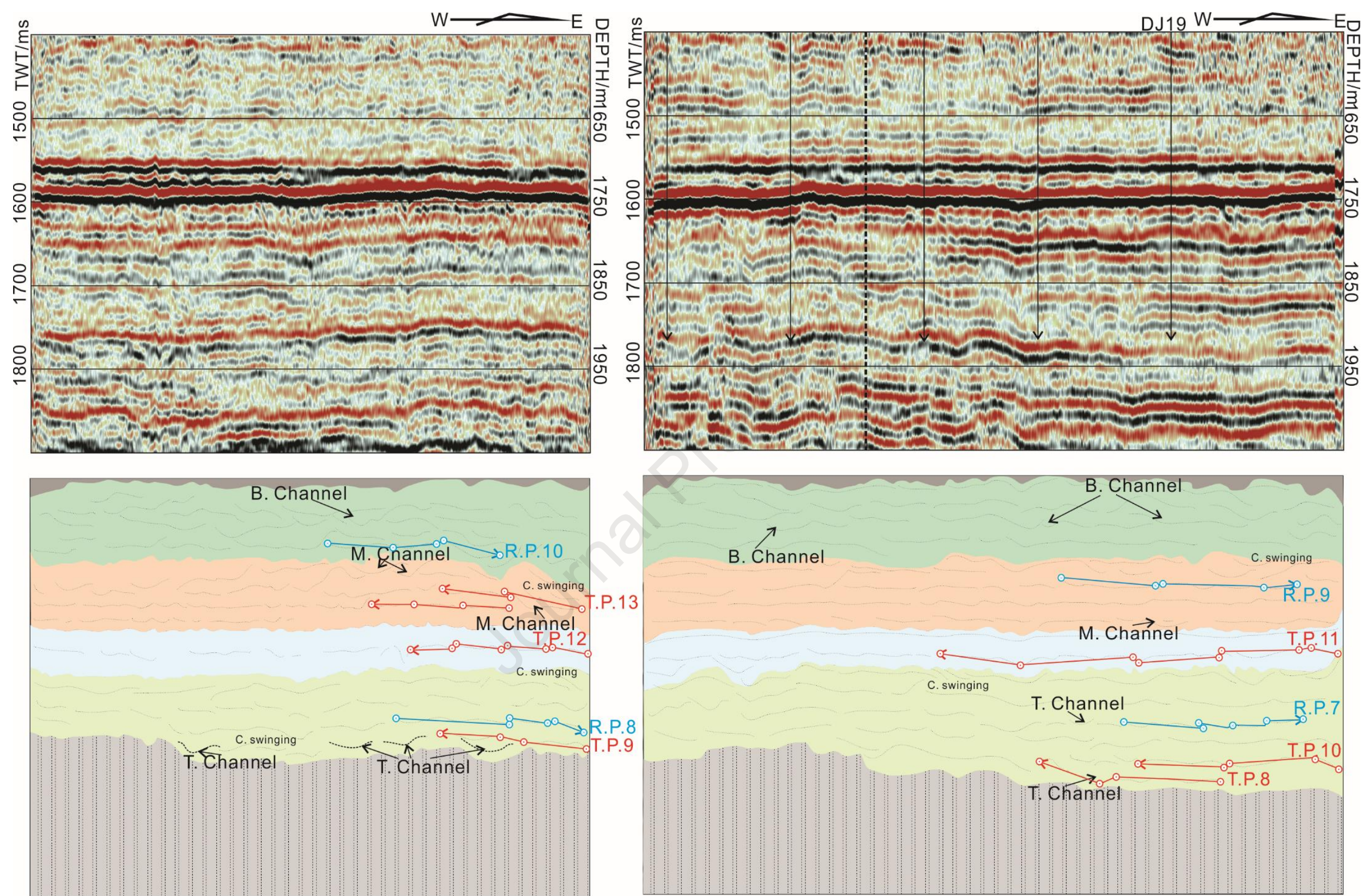

Transgression

Regression direction(T.D.)

direction(R.D.)

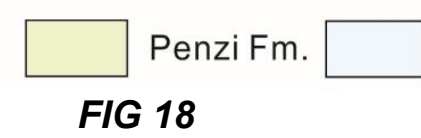

Taiyuan Fm.

Lower

Upper

FIG 18 


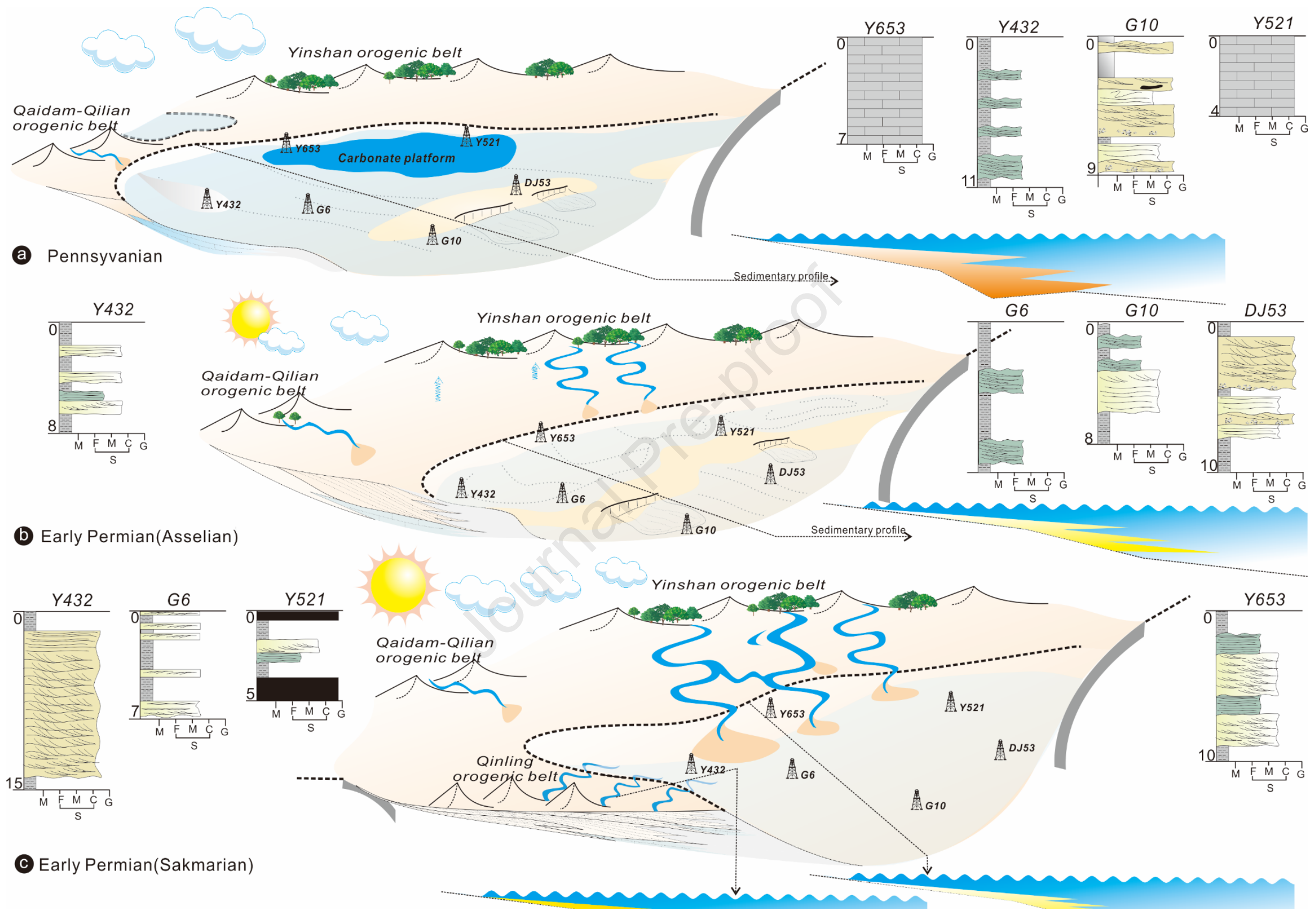


a Low transgression rate and less sediment supply S2S pattern(L.T.-L.S.)

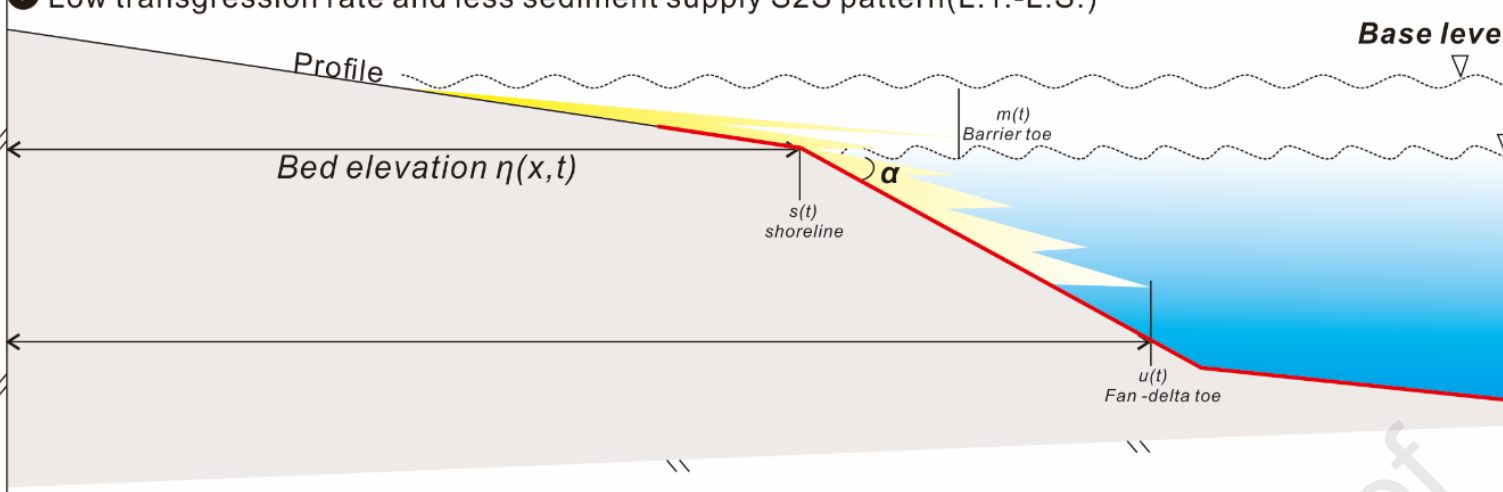

b High transgression rate and mass sediment supply S2S pattern(H.T.-M.S.)

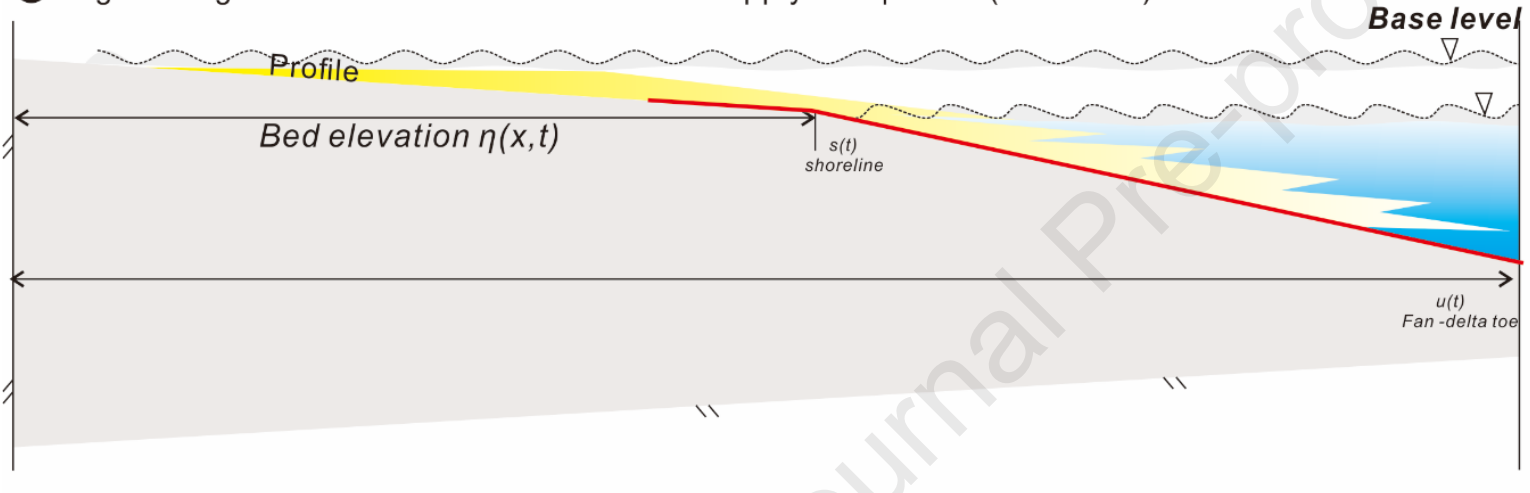

C Low transgression rate and mass sediment supply S2S pattern(L.T.-M.S.)

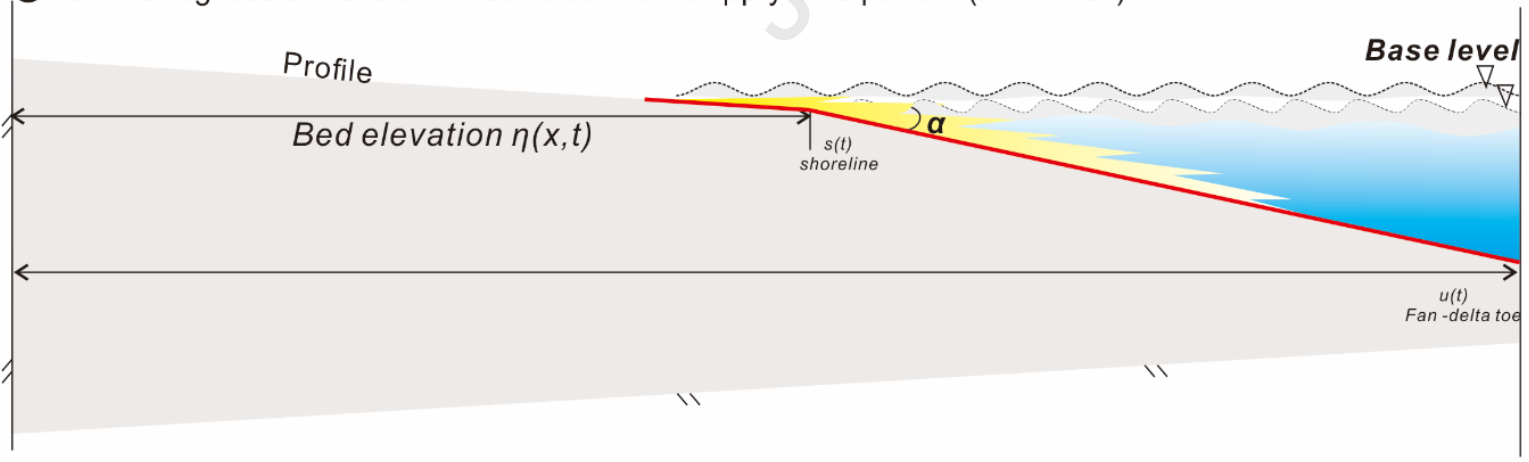

d S2S parameters (Pennsylvanian)

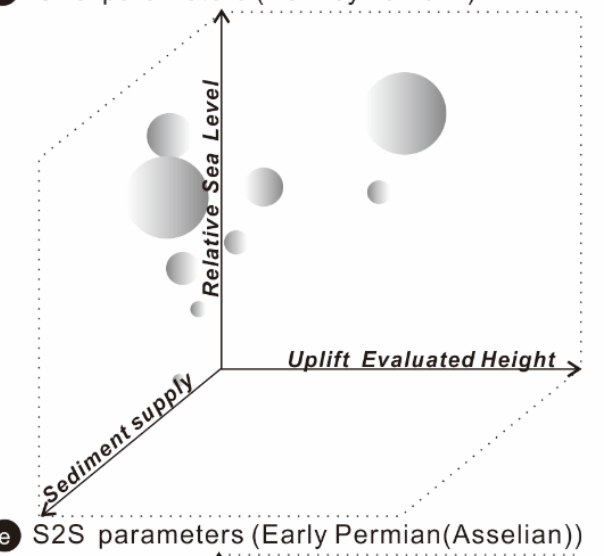

(e S2S parameters (Early Permian(Asselian))

f S2S parameters (Early Permian(Sakmarian))

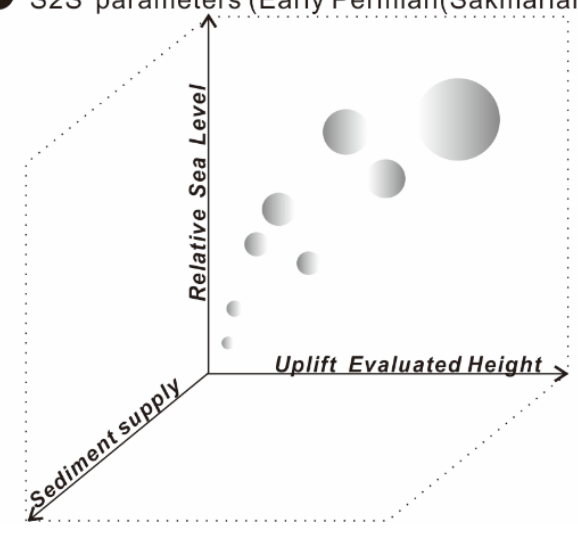




\section{Highlight}

1. Identified provenance area of the eastern margin of the Ordos Basin transfer from the QaidamQilian orogenic belt to multiprovenance areas during the Pennsylvanian the late Carboniferousearly Permian.

2. Reconstructed the clockwise evolution process of the paleo sea level in the eastern margin of the Ordos Basin during the Paleozoic

3. Identified different types of source-to-sink systems insight from the spatial discrepancy of the sea level and sediment supply.

4. Proposed a integrated method to determine the dominating factors influencing the transgression/regression process 


\section{Declaration of interests}

$\bigotimes$ The authors declare that they have no known competing financial interests or personal relationships that could have appeared to influence the work reported in this paper.

$\square$ The authors declare the following financial interests/personal relationships which may be considered as potential competing interests: 